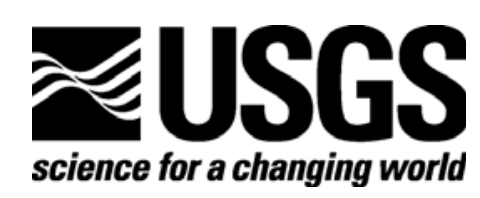

\title{
Evaluation of U.S. Geological Survey Monitoring-Well Network and Potential Effects of Changes in Water Use, Newlands Project, Churchill County, Nevada
}

Scientific Investigations Report 2004-5246

Prepared in cooperation with CHURCHILL COUNTY

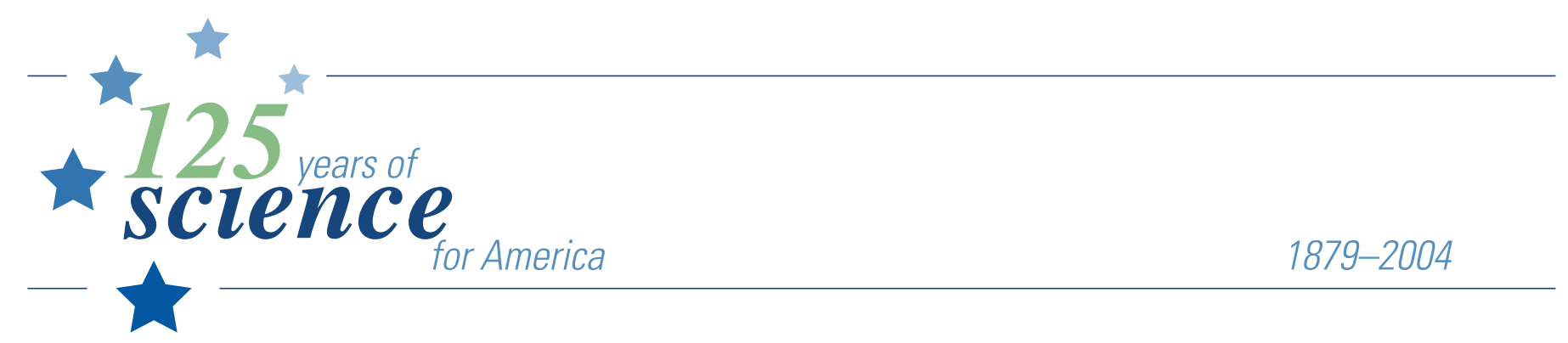

U.S. Department of the Interior 
(Back of Cover) 


\section{Evaluation of U.S. Geological Survey Monitoring-Well Network and Potential Effects of Changes in Water Use, Newlands Project, Churchill County, Nevada}

By Douglas K. Maurer, Ralph L. Seiler, and Sharon A. Watkins

U.S. GEOLOGICAL SURVEY

Scientific Investigations Report 2004-5246

Prepared in cooperation with CHURCHILL COUNTY 


\title{
U.S. DEPARTMENT OF THE INTERIOR GALE A. NORTON, Secretary
}

\author{
U.S. GEOLOGICAL SURVEY
}

CHARLES G. GROAT, Director

Any use of trade, product, or firm names in this publication is for descriptive purposes only and does not imply endorsement by the U.S. Government

For additional information contact:

District Chief

U.S. Geological Survey 333 West Nye Lane, Room 203

Carson City, NV 89706-0866

email: GS-W-NVpublic-info @usgs.gov

http://nevada.usgs.gov
Copies of this report can be purchased from:

U.S. Geological Survey Information Services

Building 810

Box 25286, Federal Center

Denver, CO 80225-0286 


\section{CONTENTS}

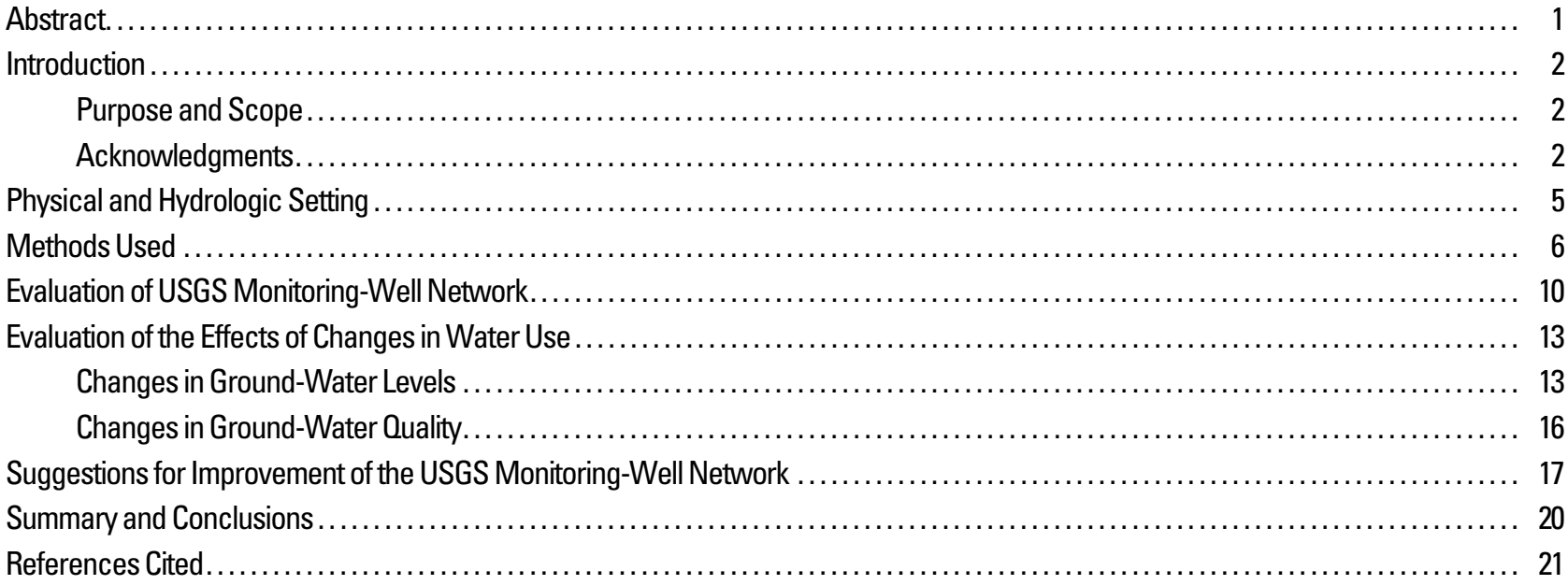

\section{FIGURES}

1. Map showing location of Carson River basin, Carson Desert, Lahontan Valley, and nearby geographic features ........... 3

2. Map showing location of irrigated lands of the Carson Division of the Newlands Project, general direction of shallow ground-water flow, and geographic features of Lahontan Valley. ....

3. Map showing approximate location of irrigated land, land where water-rights have been purchased, location of monitoring wells, and wells where water-level declines from the early 1990's to 2003 are 1 foot or less and greater than 1 foot. ....

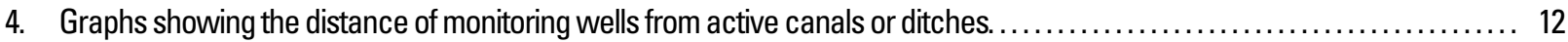

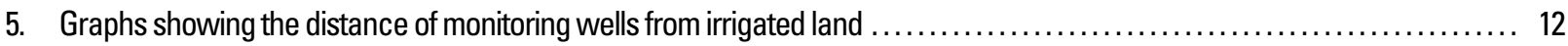

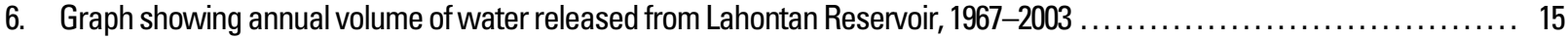

7. Graph showing relation between water-level change between $1992-95$ and 2003 and distance from canals ............. 16

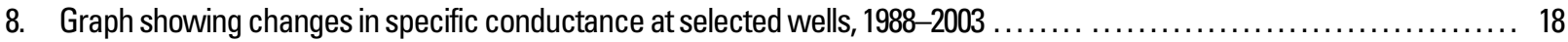

9. Map showing location of monitoring wells where continued monitoring would be useful, and where monitoring could be discontinued.

\section{TABLES}

1. Distance and direction between monitoring wells and nearest canal, ditch, or reservoir and nearest irrigated field in $2003 \ldots 9$

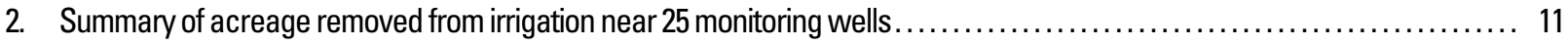

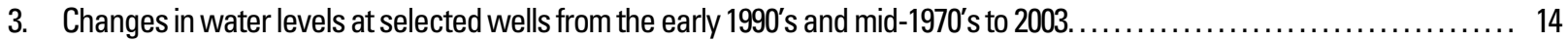




\section{APPENDIXES}

A. Monitoring well measurement frequency 1998-2003, site identifier, location, and well construction data................ 24

B. Truckee-Carson Irrigation District serial numbers of parcels near monitoring wells and summary of parcel size, average distance of parcel from well, gradient direction, irrigation history for water years 1992 through 2003, and irrigation prior to 1992 for parcels not irrigated 1992-2003. .

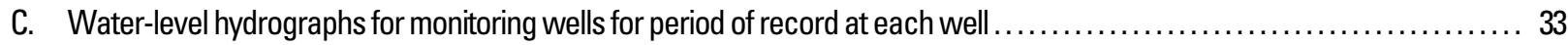

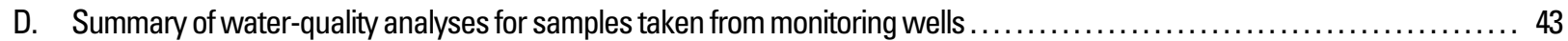

\section{CONVERSION FACTORS AND VERTICAL DATUM}

\begin{tabular}{rll}
\hline Multiply & By & To obtain \\
acre & 4,047 & square meter \\
acre foot (acre-ft) & 0.001233 & cubic hectometer \\
cubic hectometer per year \\
acre foot per year (acre-ft/yr) & 0.001233 & cubic meter per second \\
cubic foot per second (ft $\left.{ }^{3} / \mathrm{s}\right)$ & 0.02832 & meter \\
foot (ft) & 0.3048 & millimeter \\
inch (in.) & 25.4 & millimeter per year \\
inch per year (in/yr) & 25.4 & kilometer \\
mile (mi) & 1.609 & square kilometer \\
\hline
\end{tabular}

Temperature: Degrees Celsius $\left({ }^{\circ} \mathrm{C}\right)$ can be converted to degrees Fahrenheit $\left({ }^{\circ} \mathrm{F}\right)$ by using the formula ${ }^{\circ} \mathrm{F}=\left[1.8\left({ }^{\circ} \mathrm{C}\right)\right]+32$. Degrees Fahrenheit can be converted to degrees Celsius by using the formula ${ }^{\circ} \mathrm{C}=0.556\left({ }^{\circ} \mathrm{F}-32\right)$.

Sea level: In this report, "sea level” refers to the National Geodetic Vertical Datum of 1929 (NGVD of 1929, formerly called "Sea-Level Datum of 1929"), which is derived from a general adjustment of the first-order leveling networks of the United States and Canada.

\section{Metric water-quality units used in this report:}

$\mu \mathrm{g} / \mathrm{L}$, micrograms per liter

$\mu \mathrm{S} / \mathrm{cm}$, microsiemens per centimeter at $25^{\circ} \mathrm{C}$

$\mathrm{mg} / \mathrm{L}$, milligrams per liter 


\title{
Evaluation of U.S. Geological Survey Monitoring-Well Network and Potential Effects of Changes in Water Use, Newlands Project, Churchill County, Nevada
}

\author{
by Douglas K. Maurer, Ralph L. Seiler, and Sharon A. Watkins
}

\section{Abstract}

Domestic wells tapping shallow ground water are an important source of potable water for rural residents of Lahontan Valley. For this reason, the public has expressed concern over the acquisition of water rights directed by Public Law 101-618. The acquisition has resulted in removal of land from irrigation, which could cause shallow domestic wells to go dry and adversely affect shallow ground-water quality.

Periodic water-level measurements and water-quality sampling at a monitoring-well network developed by the U.S. Geological Survey (USGS) provided data to evaluate the potential effects of changes in water use. The USGS, in cooperation with Churchill County, analyzed these data and the monitoringwell network to determine if the network provides an adequate means to measure the response of the shallow aquifer to changes in water use, and to determine if measurable changes have taken place.

To evaluate the USGS monitoring-well network, wells were characterized by their distance from active canals or ditches, and from currently (2003) or formerly irrigated land. An analysis of historical data showed that about 9,800 acres of land have been removed from irrigation, generally from the late 1990 's to 2003. Twenty-five wells in the network are within about 1 mile of fields removed from irrigation. Of the 25 wells, 13 are within 300 feet of canals or ditches where seepage maintains stable water levels. The 13 wells likely are not useful for detecting changes caused by reductions in irrigation. The remaining 12 wells range from about 400 to 3,800 feet from the nearest canal and are useful for detecting continued changes from current reductions in irrigation. The evaluation showed that of the 75 wells in the network, only 8 wells are likely to be useful for detecting the effects of future (after 2003) reductions in irrigation.

Water levels at most of the monitoring wells near irrigated land have declined from 1998 to 2003 because of drought conditions and below normal releases from Lahontan Reservoir. This period coincides with the period of irrigation reductions, tending to mask declines directly caused by the reductions. It is likely that seepage from the diffuse network of canals and ditches in Lahontan Valley also masks declines caused by reductions in irrigation. In addition, the limited number of monitoring wells near land removed from irrigation, yet more than 300 feet from an active canal, does not allow a valid statistical correlation between reductions in irrigation and waterlevel declines.

Water-level declines between the last two periods of below normal releases from Lahontan Reservoir, 1992-95 and 20002003, ranged from 0.4 to 4.2 feet at 11 monitoring wells near land removed from irrigation. The maximum observed water declines were about 2 to 4 feet in three wells in the southern part of Lahontan Valley. The three wells are near or surrounded by more than 1,000 acres removed from irrigation, are now more than 3,600 feet from continued irrigation, and are within 300 feet of a canal with greatly decreased use. Water levels generally rose in monitoring wells near Stillwater, Nevada, even though large amounts of nearby land were removed from irrigation. This was likely caused by conditions in 2003 that were not as dry as those in the early 1990's and additional seepage from the increased use and stage of canals for delivery of water to wetland areas.

Five wells have been sampled since the late 1990's and two wells have been sampled since 2000 to evaluate long-term changes in water quality. Specific conductance of water sampled from these wells was used to evaluate changes in water quality. One well shows a large decline in specific conductance that may be related to changes in water use. In three other wells that showed a decrease in specific conductance it is uncertain if the decrease was related to changes in water use because samples were not collected shortly before and after the time land was removed from irrigation.

Additional wells would improve the monitoring-well network. The best locations for the new wells would be near lands where reductions in irrigation will likely occur, yet distant from irrigation canals or ditches. Water-level measurements and water-quality samples could be obtained prior to removal of irrigation, and continue after removal of irrigation. During future periods of greater releases from Lahontan Reservoir, continued monitoring of wells near reductions in irrigation would show if water levels continue to decline and the magnitude of total decline. 


\section{Evaluation of USGS Monitoring-Well Network and Potential Effects of Changes in Water Use, Newlands Project}

\section{Introduction}

From 1903 to 1915, the Bureau of Reclamation (BOR) constructed the Truckee Canal to divert water from the Truckee River and Lahontan Dam on the Carson River for development of the Newlands Project, one of the first reclamation projects in the Nation (fig. 1; Bureau of Reclamation, 1988). Shortly after construction was completed, delivery of water began to fields in Lahontan Valley (the name generally applied to the irrigated part of the Carson Desert). The Newlands Project stores water from the Carson and Truckee Rivers for irrigation of about 56,000 acres of land (average 1984-90) in Lahontan Valley (figs. 1 and 2). These irrigated lands form the Carson Division of the Newlands Project.

The construction of water-storage reservoirs, the addition of an extensive system of canals and drains, and the application of irrigation water to fields have altered ground-water levels and ground-water quality in Lahontan Valley (Seiler and Allander, 1993, p. 12-13; Lico and Seiler, 1994, p. 63). Shallow ground water in Lahontan Valley varies greatly in quality (Glancy, 1986, p. 41), and generally degrades towards the north, east, and south from the center of the valley (Lico and Seiler, 1994, p. 31). Poor-quality ground water discharges to deep open drains and is carried to wetlands at Carson Lake and the Stillwater Wildlife Management Area (fig. 2). Delivery of poorquality water containing high concentrations of trace elements to these wetlands has resulted in habitat degradation and accumulation of potentially toxic concentrations of arsenic and selenium in the biota (Hoffman and others, 1990).

Domestic wells tapping shallow ground water are currently (2003) an important source of potable water for rural residents of Lahontan Valley and, consequently, the quality and quantity of shallow ground water are important public issues. The Truckee-Carson-Pyramid Lake Water Rights Settlement Act of 1990 (Public Law 101-618) directed the U.S. Fish and Wildlife Service (USFWS) to acquire water for wetland areas in the Carson Desert. The public has expressed concern that acquisition of water rights and delivery of water directly to the wetland areas could cause shallow domestic wells to go dry and adversely affect shallow ground-water quality.

In 1992, the USGS, in cooperation with the USFWS, developed a network of 126 monitoring wells screened in the shallow and intermediate aquifers in Lahontan Valley and began periodic water-level measurements (Seiler and Allander, 1993, p. 2). From 1994 to 2003, in cooperation with Churchill County, water-levels were measured by the USGS at 75 monitoring wells to determine the effects of changes in water use. Also in cooperation with Churchill County, water-quality sampling and analysis of five wells began in 1998 from one to three times a year, generally during the irrigation and non-irrigation season.

As Lahontan Valley becomes increasingly urbanized, an additional concern is that shallow ground-water quality may degrade from development in residential areas where septic tanks will be utilized. In 2000, two wells were installed in an area currently covered by sparse native vegetation but planned for subdivision into 1 -acre lots serviced by individual wells and septic tanks. The two monitoring wells were sampled once or twice yearly.

Water-level and water-quality data collected from the USGS monitoring-well network, and the network itself, need to be evaluated to determine whether the locations and distribution of monitoring wells provide a reasonable means to measure the response of the shallow aquifer to changes in land and water use, and to determine whether measurable changes have taken place. In 2003 the USGS, in cooperation with Churchill County, began an evaluation of the network to answer these questions.

\section{Purpose and Scope}

The purpose of this report is to present an evaluation of the adequacy of the current monitoring-well network in Lahontan Valley for detecting water-level and water-quality changes caused by changes in water use, and to present an analysis of measured changes in water levels and water quality. The 75 monitoring wells in the network are characterized by their distance from canals or ditches, and distance from currently or formerly irrigated lands. The acreage and irrigation history of land where water-rights have been purchased was determined for the period 1992-2003. The characterizations were used to evaluate the network and propose changes in the network.

Water levels measured at 75 wells from 1974 to 2003 and concentrations of major inorganic constituents and nutrients from seven wells sampled from 1988 to 2003 are presented. Water level changes were evaluated by comparison with water levels measured in the early 1990's, the last period of below normal releases from Lahontan Reservoir. Specific conductance changes were evaluated graphically. Linear regressions were made to examine the relation between water-level decline and the acreage and distance of land removed from irrigation. Measured changes in water levels and quality are described in terms of the magnitude of water-level decline, specific conductance, distance from and acreage of land removed from irrigation, and distance from active canals or ditches and continued irrigation.

\section{Acknowledgments}

The authors thank Richard Grimes and James Parden of the USFWS, and Ruth Danner of Nevada State Lands for providing information on the location of lands where water rights have been purchased; Steven Munts and Roger LeSueur of the Bureau of Reclamation, Fallon Field Office, for providing access to aerial photographs of irrigated lands and irrigation history; and David Overvold of the Truckee-Carson Irrigation District (TCID) for providing information on the use of irrigation canals and ditches. 


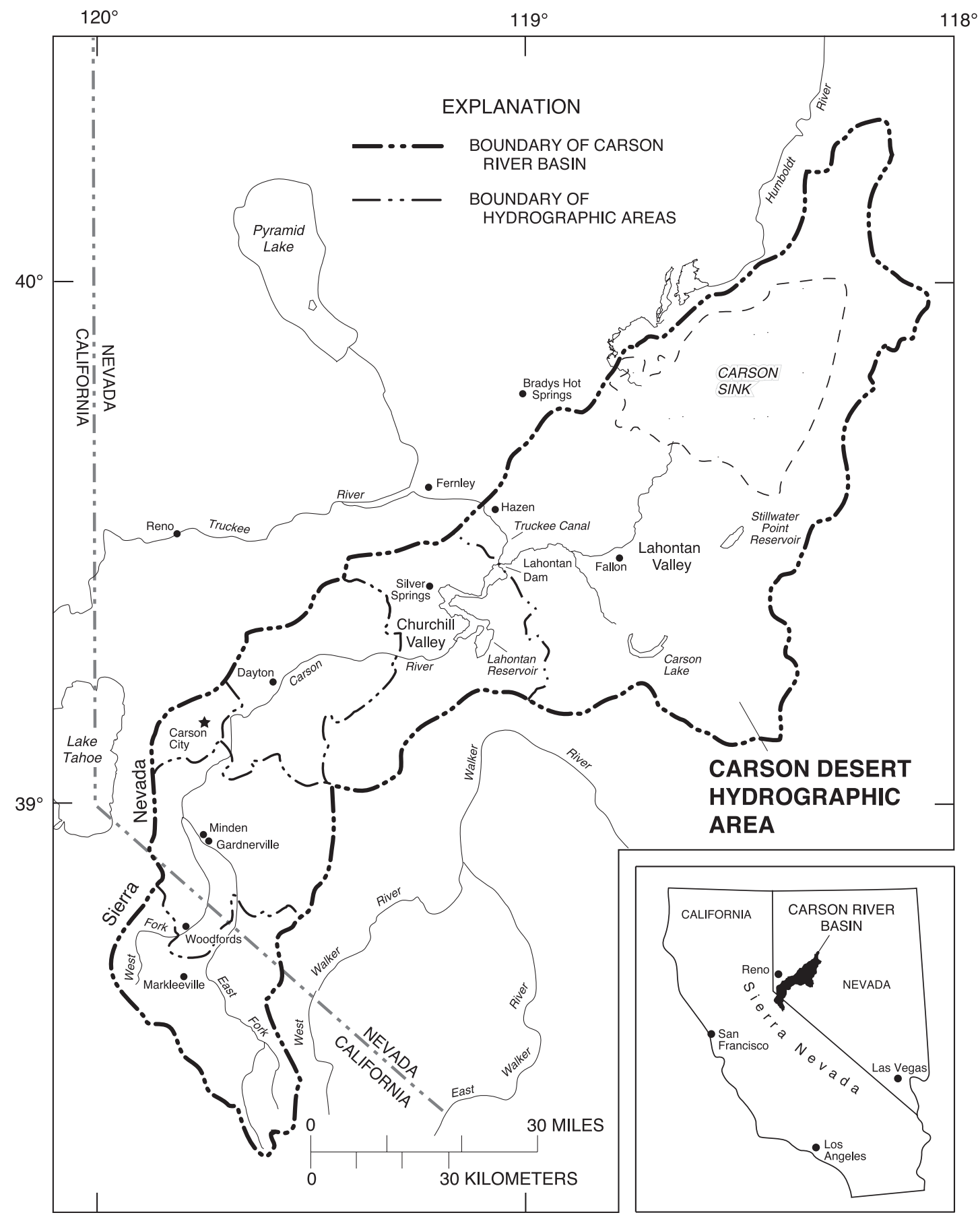

Figure 1. Location of Carson River basin, Carson Desert, Lahontan Valley, and nearby geographic features. 


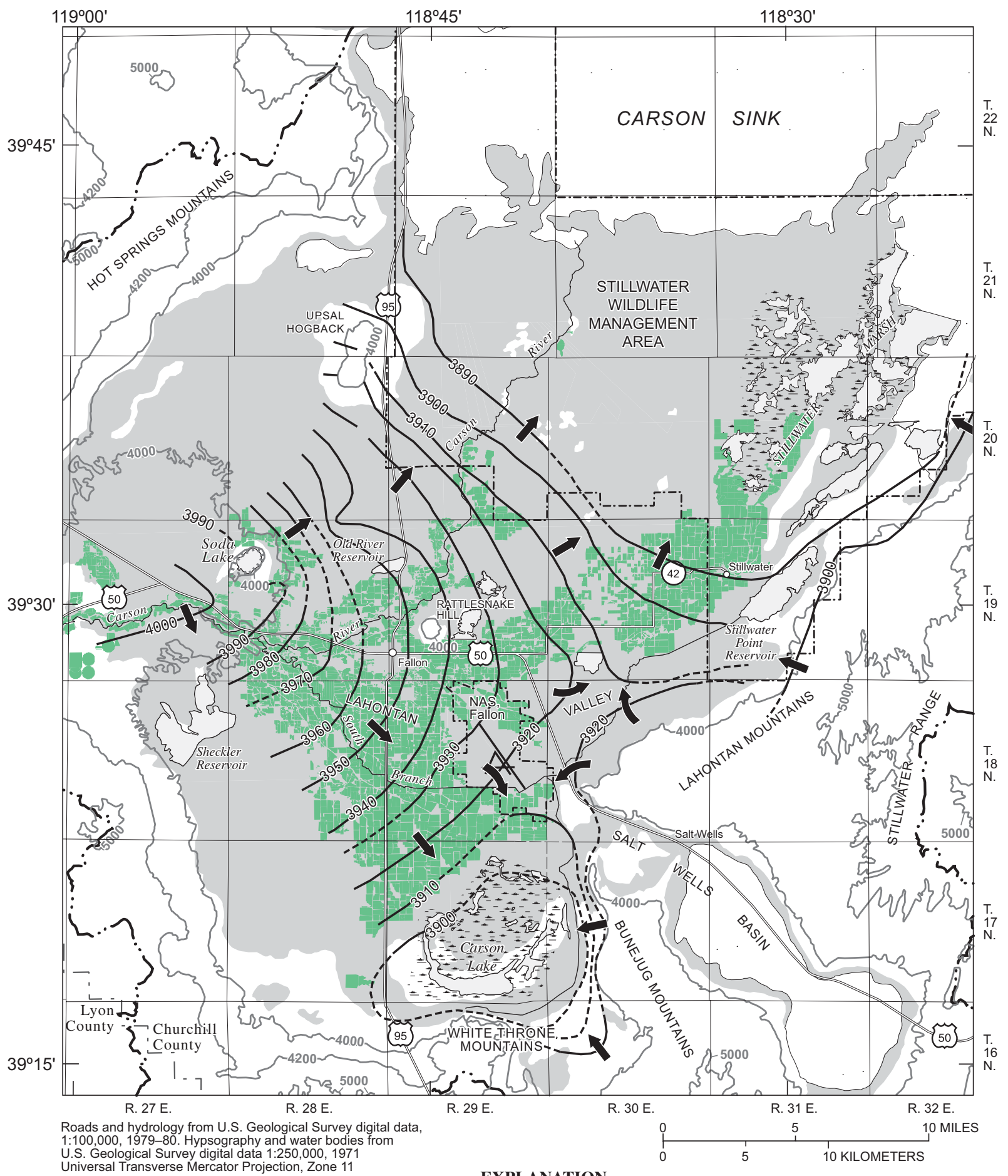

U.S. Geological Survey digital data 1:250,000, 1971
Universal Transverse Mercator Projection, Zone 11

EXPLANATION

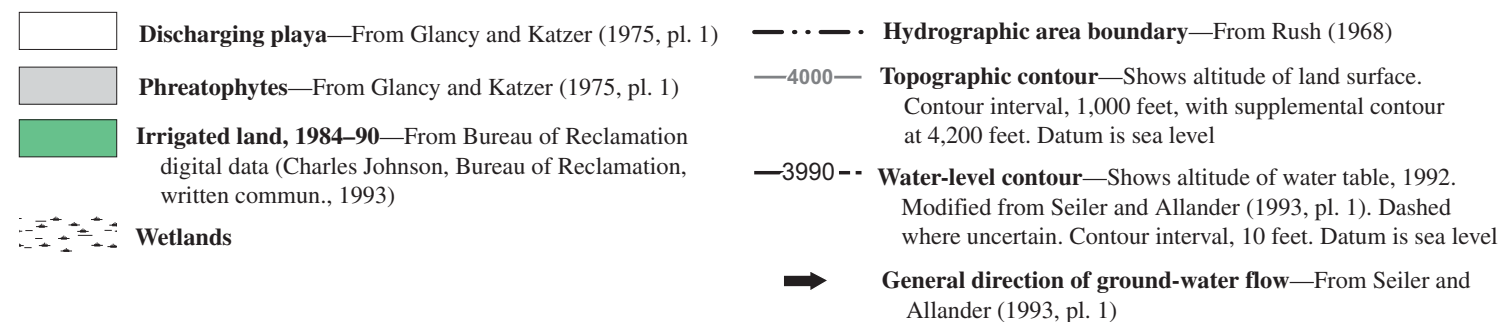

Figure 2. Location of irrigated lands of the Carson Division of the Newlands Project, general direction of shallow ground-water flow, and geographic features of Lahontan Valley. 


\section{Physical and Hydrologic Setting}

The physical and hydrologic setting of Lahontan Valley has been dominated by the Carson River over geologic time. During Pleistocene time ( 2 million to 10 thousand years ago), lakes formed in the Carson Desert with water levels rising and falling to complete dryness several times under the influence of changing glacial climates (Axelrod, 1956; Morrison, 1964). During high stands, the lakes coalesced to form ancient Lake Lahontan having a maximum depth of more than $500 \mathrm{ft}$ in the Carson Desert (Davis, 1978, p. 2; Morrison, 1991, p. 288). During high stands of Lake Lahontan, thick clay beds were deposited in the deeper parts of Lake Lahontan, deltas were formed on the western side of the valley where the Carson River entered the lake, and sand and gravel beaches and bars were formed by wave action along the shorelines (Morrison, 1964, p. 28-71). During interglacial periods when Lake Lahontan was dry, large sand-dune and sand-sheet complexes covered much of the valley floor and the Carson River meandered across the valley floor forming relict river channels which are now buried. As lake levels rose and fell, these depositional environments moved back and forth across the valley floor, creating a complex mixture of Quaternary sediments more than 2,500-ft thick (Maurer and others, 1996, pl. 1).

Since construction of Lahontan Reservoir, irrigation with surface-water has dominated the hydrologic system. The outflow from Lahontan Reservoir has averaged about 367,000 acre-ft/yr from 1967 to 2002 (Berris and others, 2003, p. 201). The irrigation season is generally from April through October, during which an average of about 190,000 acre-ft/yr is delivered to 1,500 farm headgates through about $340 \mathrm{mi}$ of canals and lateral ditches. About $350 \mathrm{mi}$ of drains route return flow and ground-water seepage to wetland areas (Maurer and others, 1996, p. 16 and 24). Streamflow in Lahontan Valley not used for irrigation, and streamflow in drains, flows north to the Carson Sink, northeast to wetlands in the Stillwater Wildlife Management Area, or south to the Carson Lake wetlands. Water released from Lahontan Reservoir is generally of good quality with dissolved-solids concentrations of about $200 \mathrm{mg} / \mathrm{L}$ (Lico and Seiler, 1994, p. 26).

Alfalfa is the main irrigated crop in the valley, along with pasture, and some cereal and vegetable crops. Cottonwood trees are abundant near homes and ranches in the irrigated part of the valley, willows line many of the canals, and cattails fill most drains. Non-irrigated areas are sparsely vegetated with greasewood, rabbitbrush, saltgrass, and marsh grasses. The Carson Sink is largely barren.

The rapidly growing city of Fallon is the major population center in the area. The population of Fallon, including Naval Air Station Fallon, increased from about 3,000 in the early 1970's (Glancy, 1986, p. 27) to 8,800 in 2000 (U.S. Census Bureau, 2004a). About 15,000 people also live in the surrounding unincorporated areas of the county (U.S. Census Bureau, 2004b). Agriculture is the major economic base in the area, followed by employment at the Naval Air Station.
The floor of Lahontan Valley is a relatively flat plain, sloping from about 3,960 ft above sea level near Fallon to about 3,870 ft near the Carson Sink (fig. 1). Several low-lying mountain ranges surround the valley on the north, south, and west rising to about 5,500 $\mathrm{ft}$ in altitude, and the Stillwater Range bounds the valley on the east, rising to $8,800 \mathrm{ft}$ in altitude (fig. 2).

Lahontan Valley is in the rain shadow of the Sierra Nevada to the west and received an average $5.3 \mathrm{in} / \mathrm{yr}$ of precipitation from 1971-2000 (National Oceanic and Atmospheric Administration, 2002, p. 12). Average maximum temperatures are about $90^{\circ} \mathrm{F}$ in July and August, and average minimum temperatures are about $17^{\circ} \mathrm{F}$ in December and January (National Oceanic and Atmospheric Administration, 2002, p. 8). Open-water evaporation is about $5 \mathrm{ft} / \mathrm{yr}$ (Bureau of Reclamation, 1987, p. 1-7).

Previous studies in the area provide a general understanding of the aquifer systems in the study area and the large-scale direction of ground-water flow. However, the complex lithology of Quaternary sediments and the complex surface-water distribution system of canals and drains make a detailed understanding difficult without site-specific investigations. Studies have shown that the direction of ground-water flow, at a small scale, can vary greatly and is controlled by local irrigation practices and the location of canals and drains (Lico and others, 1986, p. 93; Lico, 1992, p. 8).

Glancy (1986) delineated three sedimentary aquifers in the Carson Desert: the shallow, intermediate, and deep aquifers. He also provided the first detailed description of the basalt aquifer, the sole source of water for the city of Fallon, the Naval Air Station, and the Fallon Paiute-Shoshone Tribe. The basalt aquifer and surrounding sedimentary aquifers are described in detail by Maurer and Welch (2001), and the shallow aquifer and effects of changes in water use are described by Seiler and Allander (1993) and Herrera and others (2000). The geohydrology and water budget of Lahontan Valley are described in detail by Maurer and others (1996),

On the basis of water hardness, Glancy (1986, p. 41) defined the shallow aquifer to extend from the water table to a depth of $50 \mathrm{ft}$ below land surface. The shallow aquifer is an unconfined aquifer. Prior to the Newlands Project, the depth to water in the shallow aquifer was 5 to $10 \mathrm{ft}$ below land surface within 1 to $2 \mathrm{mi}$ of the main channels of the Carson River, increasing to over $25 \mathrm{ft}$ in areas between the river channels (Seiler and Allander, 1993, p. 13). After operation of the Newlands Project, infiltration from the canal system and beneath irrigated land caused water levels to rise more than $15 \mathrm{ft}$ in some parts of the shallow aquifer, while installation of drains caused water levels to decline in other areas, creating a more uniform depth to water (Seiler and Allander, 1993, p. 10-13). Presently (2003), the depth to water beneath much of the valley floor is from 5 to $10 \mathrm{ft}$ below land surface (Seiler and Allander, 1993, p. 13), and likely is controlled by the depth of drains which were excavated to depths of 4 to $8 \mathrm{ft}$ below land surface (Herrera and others, 2000, p. 8 and 10). 


\section{Evaluation of USGS Monitoring-Well Network and Potential Effects of Changes in Water Use, Newlands Project}

The hardness in ground water in the shallow aquifer is greater than $70 \mathrm{mg} / \mathrm{L}$ (as CaCO3), which is considered moderately hard (Hem, 1989, p. 159). The shallow aquifer is characterized by abrupt changes in lithology and ground-water quality over short distances (Glancy, 1986, p. 41). The dissolved-solids concentration of water in the shallow aquifer is generally between 200 and $600 \mathrm{mg} / \mathrm{L}$ beneath the west-central part of the valley, increasing to more than $10,000 \mathrm{mg} / \mathrm{L}$ about $10 \mathrm{mi}$ north, east, and south of Fallon (Lico and Seiler, 1994, p. 33). The stable isotope composition of water in the shallow aquifer is consistent with recharge by water applied for irrigation (Welch and others, 1997, p. A28 and A31).

Maurer and Welch (2001, p. 35) observed an abrupt change in the stable isotope composition at a depth of $50 \mathrm{ft}$, which suggests that water in the intermediate aquifer near the center of Lahontan Valley was recharged prior to construction of Lahontan Reservoir. Ground water from wells deeper than $50 \mathrm{ft}$ is distinctly lighter in its isotopic composition than ground water from wells shallower than $50 \mathrm{ft}$. This indicates that, near the center of the valley, recharge from the Carson River is restricted to the upper $50 \mathrm{ft}$ (the shallow aquifer) under the current hydrologic regime. On the western side of Lahontan Valley, near to and west of Soda Lake, recharge from the Carson River to the intermediate aquifer has occurred to depths of over $100 \mathrm{ft}$ (Lico and Seiler, 1994, p. 16).

The intermediate aquifer extends from a depth of $50 \mathrm{ft}$ below land surface to between 500 and 1,000 ft. The intermediate aquifer is a confined aquifer with water levels in wells rising to within 10 to $40 \mathrm{ft}$ of land surface. The lower limit of its extent is the depth of sediments bearing fresh water near the basalt aquifer (Glancy, 1986, p. 51). However, the vertical extent of fresh water in the intermediate aquifer is poorly known because only 3 wells slightly more than 500-ft deep and one well 1,700ft deep are known to have been sampled (Whitney, 1994, table 36; Lico and Seiler, 1994, p. 36). Beneath the west-central part of the valley, the intermediate aquifer is characterized by relatively fresh, soft water with hardness generally less than $25 \mathrm{mg} / \mathrm{L}$ (Glancy, 1986, p. 56). The dissolved-solids concentration of water in the intermediate aquifer ranges from 200 to $600 \mathrm{mg} / \mathrm{L}$ beneath the west-central part of the valley, and increases to more than $1,000 \mathrm{mg} / \mathrm{L}$ about $8 \mathrm{mi}$ north of Fallon, about $5 \mathrm{mi}$ east of Fallon, and about $6 \mathrm{mi}$ south of Fallon (Lico and Seiler, 1994, p. 33).

The deep aquifer is defined to extend from 500 to $1,000 \mathrm{ft}$ below land surface to depths of several thousand feet, and is thought to be mainly non-potable (Glancy, 1986, p. 51 and 60). Little is known about its water quality because only one well in the deep aquifer (1,700-ft deep) is known to have been sampled (Lico and Seiler, 1994, p. 36).

Glancy (1986) delineated the extent of the basalt aquifer using lithologic descriptions from driller's logs and surface electrical-resistivity soundings. Maurer and Welch (2001) used additional driller's logs and seismic reflection soundings to generally confirm the extent and configuration of the basalt aquifer as delineated by Glancy (1986). The aquifer is an asymmetrical, mushroom-shaped body of basalt exposed at Rattlesnake Hill with the bulk of the basalt surrounded by the sedimentary aqui- fers (Glancy, 1986, p. 13-14). In plan view, the basalt aquifer is about $10 \mathrm{mi}$ long in a southwest to northeast direction and about 4 mi wide. Driller's logs show the basalt is 400-600 ft below land surface about $2 \mathrm{mi}$ southwest of Rattlesnake Hill, and about 200-300 ft below land surface 5-7 mi northeast of Rattlesnake Hill.

Ground water in the shallow aquifer flows from west to east (fig. 2). North of Fallon, ground-water flow is generally to the northeast toward the Carson Sink and south of Fallon, flow is southeastward toward Carson Lake (Seiler and Allander, 1993, pl. 1; Glancy, 1986, p. 42). Water-level fluctuations in the shallow aquifer show that it is recharged by infiltration of surface water during the irrigation season (Glancy, 1986, p. 39). Water-level contours for wells screened in the intermediate aquifer show that ground-water flows in directions similar to the shallow aquifer (Glancy, 1986, p. 53). The shallow aquifer has the potential to recharge the intermediate aquifer in the west-central part of the valley as shown by higher water levels in the shallow aquifer than in the intermediate aquifer (Glancy, 1986, p. 54). Isotopic data presented earlier indicates, however, that recharge of present day Carson River water to the intermediate aquifer is only occurring in the western part of Lahontan Valley. Elsewhere in the valley, ground-water flow is upward from the intermediate to the shallow aquifer where ground water is discharged to irrigation drains, by evapotranspiration of irrigated crops and natural vegetation, or by evaporation from bare soil (Glancy, 1986, p. 54).

\section{Methods Used}

The data-collection/monitoring-well network was developed in 1992 and consists of 75 wells; a combination of monitoring wells installed for previous studies in the area, generally of 1.5- to 2-in. diameter, and domestic wells of larger diameter (fig. 3; app. A). Water-level and water-quality data have been collected at some wells since the mid-1970's, at other wells installed in the mid-1980's for a regional USGS water-quality study (Whitney, 1994) and for Department of Interior irrigation-drainage studies (Rowe and others, 1991), and at others installed in 1992 for a study of the shallow aquifer (Seiler and Allander, 1993). Most wells are screened in the shallow aquifer (less than $50 \mathrm{ft}$ in depth); however, 11 wells screened in the intermediate aquifer have been included in the network to provide information on potential changes at greater depth. Waterlevel measurements are made with a standard 1/4-inch steel tape or electric tape and referenced to a measuring point and land surface near the well head. The measurements are considered accurate to the nearest $0.01 \mathrm{ft}$ for steel tapes and $0.1 \mathrm{ft}$ for electric tapes.

The frequency of water-level measurements at the network wells has changed over time. From 1992 to 1998, selected wells were measured every two weeks while other wells were measured three times a year (before, during, and after the irrigation season). To reduce monitoring costs, in 1998 the network was divided into wells with monthly, quarterly, and annual measurement frequencies (app. A). Wells measured annually are measured in late September at the end of the irrigation season. Wells 1 and 55 were plugged in 2000 and 2003, respectively. 


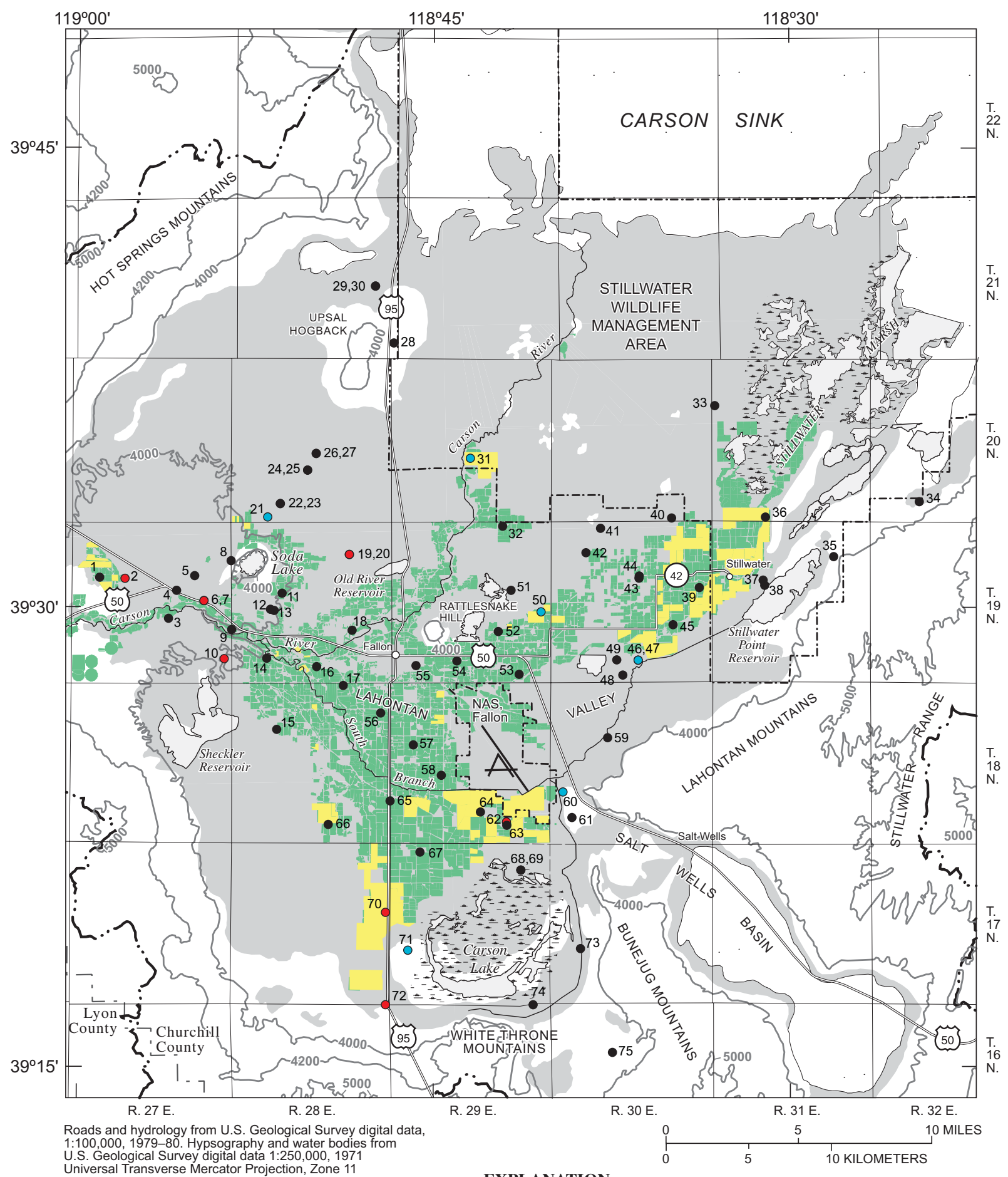

Universal Transverse Mercator Projection, Zone 11

\section{EXPLANATION}

\begin{tabular}{|c|c|c|}
\hline \multirow{2}{*}{$\begin{array}{l}\text { Discharging playa-From Glancy and Katzer (1975, pl. 1) } \\
\text { Phreatophytes_From Glancy and Katzer }(1975, \text { pl. 1) }\end{array}$} & \multicolumn{2}{|c|}{ 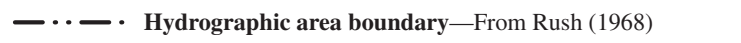 } \\
\hline & $-4000-$ & Topographic contour-Shows altitude of land surface. \\
\hline \multirow{4}{*}{$\begin{array}{l}\text { Irrigated land, 1984-90-From Bureau of Reclamation } \\
\text { digital data (Charles Johnson, Bureau of Reclamation, } \\
\text { written commun., 1993) } \\
\text { Land where water rights have been purchased, } \\
\text { approximately located, as of June 4, 2003-Modified } \\
\text { from U.S. Fish and Wildlife Service digital data } \\
\text { (Jim Parden, U.S. Fish and Wildlife Service, 2003) }\end{array}$} & & at 4,200 feet. Datum is sea level \\
\hline & & $\begin{array}{l}\text { U.S. Geological Survey monitoring well and site } \\
\text { number-Appendix A }\end{array}$ \\
\hline & $0^{21}$ & Monitoring well where water level has declined \\
\hline & $0^{20}$ & $\begin{array}{l}1 \text { foot or less from the early } 1990 \text { 's or late } 1970 \text { 's to } 2003 \\
\text { Monitoring well where water level has declined more than } \\
1 \text { foot from the early } 1990 \text { 's or late } 1970 \text { 's to } 2003\end{array}$ \\
\hline
\end{tabular}

Figure 3. Approximate location of irrigated land, land where water-rights have been purchased, location of monitoring wells, and wells where water-level declines from the early 1990's to 2003 are 1 foot or less and greater than 1 foot. 


\section{Evaluation of USGS Monitoring-Well Network and Potential Effects of Changes in Water Use, Newlands Project}

Water-quality samples were collected from 7 of the network wells one to three times a year (app. A), usually once during the irrigation season and once during the non- irrigation season. Before sample collection, wells were purged of at least three casing volumes of water and in most cases, field measurements had stabilized in a flow-through chamber that measured temperature, $\mathrm{pH}$, dissolved oxygen, and specific conductance. At some of the wells, production was not sufficient to maintain a constant flow through the flow-through chamber. At these wells, samples were collected after three casing volumes had been pumped. Filtered samples were collected after passing through a 0.45 micron in-line capsule filter. Samples were analyzed for major inorganic constituents and nutrients. Samples for nutrients were stored on ice or in a refrigerator until they were shipped to the USGS National Water-Quality Laboratory (NWQL) for analysis. The major inorganic constituents and nutrients were analyzed at the NWQL using methods described in Fishman and Friedman (1989) and Fishman (1993).

Ground-water flow models of selected areas of Lahontan Valley developed by Herrera and others (2000) indicate that the amount of water level decline caused by reductions in irrigation is controlled largely by the distance from active irrigation canals. For this reason, monitoring wells in the network were characterized by distance from active irrigation canals or ditches, by the distance from currently and formerly irrigated land, and by acreage of nearby lands removed from irrigation.

The distance between each monitoring well and the nearest active canal or ditch, and irrigated field was measured using a survey-type distance-measuring wheel (table 1). For wells more than about $1,000 \mathrm{ft}$ from canals or irrigated fields, distances were measured from 1:24,000 scale topographic maps or from scanned aerial photography. Twenty-five of the wells in the network are near land removed from irrigation and the distance from irrigated land has changed over time (fig. 3). For these wells, the distance from irrigated land in 2003 was used.

In addition to distance, the direction of canals and irrigated fields from the well was determined in an upgradient, downgradient, or at a lateral direction relative to ground-water flow (fig. 2 ; table 1). The direction is important because it is reasonable to assume that changes in water use upgradient from the wells will have a greater effect on water levels and water quality than changes in a lateral or downgradient direction. Changes in the use of irrigation canals over time near selected wells were determined from records of the TCID and discussions with TCID personnel (Dave Overvold, written and oral commun., 2003).

Maps provided by USFWS were used to determine which wells in the network are near reductions in irrigation (Richard Grimes, USFWS, written commun., 2003; Jim Parden, USFWS, digital geospatial data, 2003). The maps show the approximate location of land where water rights have been purchased by the USFWS and the State of Nevada. In addition, water rights have been purchased on the western side of Lahontan Valley by the Pyramid Lake Paiute Tribe and the cities of Reno and Sparks, Nev. (Dave Overvold, Truckee-Carson Irrigation District, oral commun., 2004).

The bulk of the land removed from irrigation is near the outer edges of irrigated areas near Stillwater and west and north of Carson Lake (fig. 3). Twenty-six of the wells in the network are within about $1 \mathrm{mi}$ of lands where water-rights have been purchased (as of June 4, 2003). One of the 26 wells (well 1) was plugged in 2000, so only 25 of the original 75 wells in the network were used to evaluate changes caused by reductions in irrigation. From about 1995 to 2002, irrigation continued on a sporadic basis on some parcels of land where rights were purchased because of ongoing litigation over the water-rights purchases. On other parcels, irrigation continued using water rights transferred from elsewhere in Lahontan Valley (Richard Grimes, USFWS, oral commun., 2002). These practices required an analysis to determine the irrigation history of land near the 25 wells.

To determine the irrigation history of land near the 25 wells, files showing the TCID serial numbers for parcels of land where water rights have been purchased were obtained from the USFWS (Richard Grimes, USFWS, written commun., 2003), Nevada State Lands (Ruth Danner, written commun., 2003), and TCID (David Overvold, oral commun., 2004). Acreages of individual fields in the parcels were determined from database files obtained from BOR, Fallon Field Office (Steven Munts, electronic commun., 2003). Parcel and field boundaries were transferred to 1:24,000 scale USGS topographic maps to allow measurement of the distance between wells and the nearest edge of irrigated and non-irrigated fields.

The BOR database also provided information on the irrigation history of individual fields for 1992-95, 2001, and 2002. This information was not compiled or available for 1996-2000 and 2003. The acreages of individual fields and the number of fields within each TCID parcel has changed somewhat over time (Steven Munts, BOR, Fallon Field Office, oral commun., 2003). The field numbers and acreages used in this evaluation were those delineated in 2002 and acreages calculated for parcels removed from irrigation between 1992 and 2003 can only be considered approximate.

To supplement the BOR database information for years when that data were not available (1996-2000 and 2003), aerial photographs in the form of 35-mm slides showing irrigated land near the 25 wells were digitally scanned. The slides were obtained from the BOR, Fallon Field Office for 1992-2001. The resulting images were printed at a scale of $1: 24,000$ to allow measurement of the distance between wells in the network and the nearest edge of irrigated and non-irrigated fields. Aerial photographs for the 2003 water year were not scanned, but were inspected at the BOR field office in Fallon, Nev.

Appendix B summarizes the acreage of parcels removed from irrigation, the direction of the parcel from the well in terms of ground-water flow, and the average distance of each parcel from the nearest monitoring well. The parcels where waterrights have been purchased contain from 1 to as many as 43 individual fields. The irrigation history of individual fields for 1992-2003 was summarized to obtain the irrigation history for the bulk of the fields comprising each parcel (app. B). The parcels summarized in appendix B are those closest to individual monitoring wells and considered most likely to affect water levels and water quality. Some parcels are listed in appendix B more than once if they may affect more than one well. 
Table 1. Distance and direction between monitoring wells and nearest canal, ditch, or reservoir and nearest irrigated field in 2003.

[Symbols: N, indicates none closer; * (asterisk), indicates site is near land removed from irrigation (table 2); shaded cells indicate wells less than 400 feet from nearest irrigated field and greater than 300 feet from nearest canal; directions are relative to ground-water flow; U, upgradient; L, lateral; D, downgradient.]

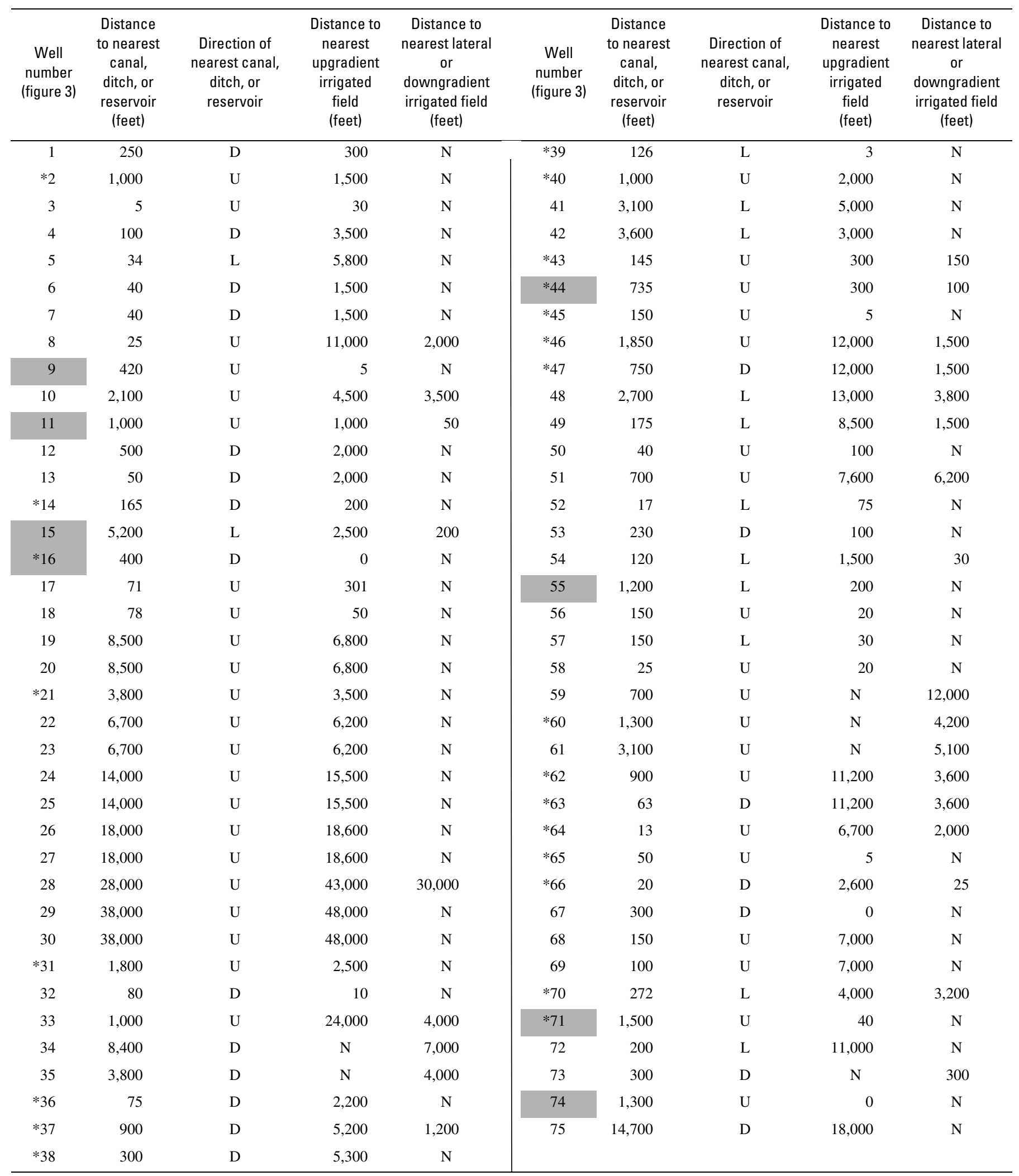


The average distance of the parcel shown in appendix B was determined by multiplying the acreage of the individual fields by their minimum distance from the well. The resulting values were totaled, and divided by the total acreage of the parcel. The resulting average distance represents the approximate center point of the parcel.

Water rights have been purchased from one to as many as 15 parcels at varying distances and directions from the 25 network wells (app. B). To evaluate the effects of removing land from irrigation, the average distance between the well and the total acreage in all parcels removed from irrigation was determined. The average distance was determined for all parcels in the same direction from the well by multiplying the acreage of the parcel by its average distance from the well. The resulting values were totaled and divided by the total acreage removed from irrigation for all parcels in an upgradient, downgradient, or lateral direction from the well. The resulting average distances are shown in table 2 , along with the year when irrigation was reduced on the bulk of the parcels, as determined from appendix B.

The average distances for acreages listed in table 2 represent an approximate center point of the total acreage removed from irrigation for purposes of comparison and evaluation. In many cases, individual fields removed from irrigation are much closer to the monitoring wells than the calculated center points. For this reason, the minimum distance between the monitoring wells and the nearest field removed from irrigation also is listed in table 2 .

\section{Evaluation of USGS Monitoring-Well Network}

Using ground-water flow simulations of the study area, Herrera and others (2000, p. 51, 52, and 54-56) determined that when irrigation water applied to fields was reduced, simulated water-level declines were greatest in the areas most distant from active canals. In contrast, when the period of flow in a canal was shortened, or when flow was completely stopped, simulated water-level declines were greatest near the canal (Herrera and others, 2000, p. 51, 52, and 54-56). The distances involved in each case were not explicitly stated; however, the cells used in the simulations were $330 \mathrm{ft}$ on each side. Simulated water-level declines caused by removing flow in a canal were generally 2 to $4 \mathrm{ft}$ in cells adjacent to the canal, but less than $1 \mathrm{ft}$ a cell-width $(330 \mathrm{ft})$ away from the canal (David E. Prudic, USGS, written commun., 2004).

These simulation results indicate that wells within about $300 \mathrm{ft}$ of active irrigation canals may be relatively insensitive to changes in irrigation practices because seepage from the canals maintains stable water levels. Thus, the effects of reducing the amount of irrigation water applied to fields likely are greatest in wells distant from active canals. To detect the effects of changes in water use and provide information in terms of distance from such changes, the monitoring-well network should have wells distributed at varying distances from irrigation canals or ditches, irrigated land, and land removed from irrigation. Because the distances that may be critical in affecting ground water are uncertain, the distribution of wells at varying dis- tances should be relatively continuous to provide information over a complete range of values. In addition, wells distant from changes in water use should be available to provide background information where changes are not taking place.

Histograms were developed to graphically show the distribution of wells at varying distances from irrigation canals or ditches and from irrigated fields (figs. 4 and 5). Thirty-two of the wells are less than $300 \mathrm{ft}$ from irrigation ditches, 12 of the wells are between 300 and 1,000 ft, and the remaining 31 wells are more than $1,000 \mathrm{ft}$ from active irrigation ditches (fig. 4). The monitoring wells were often installed at the edges of fields to reduce damage to the well from farm equipment, causing a large number to be located relatively near irrigation ditches. It is unlikely that the 32 wells within $300 \mathrm{ft}$ of canals will be useful in detecting changes caused by reductions in irrigation applications because seepage maintains relatively stable water levels near the canals. However, they will be useful to measure waterlevel changes from reductions in flow or discontinued use of individual canals.

Figure 5 shows the distance from monitoring wells to fields where irrigation is currently (2003) continuing. Eighteen wells are less than $100 \mathrm{ft}$ from irrigated fields, 10 wells are from 100 to $400 \mathrm{ft}$, and there are no wells from 400 to less than $1,200 \mathrm{ft}$. Sixteen wells are from 1,200 to less than 5,000 ft, and the remaining 31 wells are from 5,000 to 48,000 ft from irrigated land.

The wells greater than 1,200 ft from an irrigated field may be too distant to detect the effects of reductions in irrigation. Of the 28 wells less than 1,200 ft from irrigated fields, 20 are also less than $300 \mathrm{ft}$ from a canal (table 1). Because of their proximity to active canals, water-level declines caused by reduced irrigation near these 20 wells likely would be masked by seepage from the canals. Thus, only eight wells in the network (see shaded wells in table 1) likely will be useful in detecting the effects of future (after 2003) reductions in irrigation, should reductions take place near the eight wells.

From the analysis of historical irrigation, a total of about 9,800 acres of land have been removed from irrigation (app. B). Twenty-five wells in the network are within about $1 \mathrm{mi}$ of these lands (fig. 3; table 2). Near those 25 wells, parcels ranging from about 20 acres to almost 1,500 acres have been removed from irrigation, with the bulk being removed during the mid- to late1990's (table 2). The distances between the monitoring wells and the center points of parcels removed from irrigation ranged from 1,270 to $8,820 \mathrm{ft}$ in an upgradient direction, and from about 1,140 to $6,800 \mathrm{ft}$ in downgradient or lateral directions. The minimum distance between individual fields removed from irrigation and monitoring wells ranged from $0 \mathrm{ft}$ (meaning that the field surrounded the well) to $200 \mathrm{ft}$ or less at 7 wells (table 2).

Of the 25 wells within $1 \mathrm{mi}$ of land removed from irrigation, 13 are within $300 \mathrm{ft}$ of canals (table 2). These 13 wells likely are not useful for detecting changes caused by reductions in irrigation because seepage from the canals maintains relatively stable water levels. Only the remaining 12 wells, which range from 400 to $3,800 \mathrm{ft}$ from the nearest canal, may be useful for detecting continued changes from the current (2003) reductions in irrigation (see shaded wells, table 2). 
Table 2. Summary of acreage removed from irrigation near 25 monitoring wells.

[Symbols: --, indicates no acreage in that direction; shaded cells indicate wells more than 300 feet from canal; U, upgradient; D, downgradient; L, lateral]

\begin{tabular}{|c|c|c|c|c|c|c|c|}
\hline \multirow[b]{2}{*}{$\begin{array}{c}\text { Well } \\
\text { number } \\
\text { (figure 3) }\end{array}$} & \multirow{2}{*}{$\begin{array}{c}\text { Total } \\
\text { acreage } \\
\text { removed } \\
\text { from } \\
\text { irrigation } \\
\text { (appendix B) }\end{array}$} & \multicolumn{3}{|c|}{$\begin{array}{l}\text { Direction and average distance of acreage from } \\
\text { well in terms of ground-water flow }\end{array}$} & \multirow{2}{*}{$\begin{array}{l}\text { Minimum } \\
\text { distance } \\
\text { to nearest } \\
\text { field } \\
\text { removed } \\
\text { from } \\
\text { irrigation } \\
\text { (feet) }\end{array}$} & \multirow{2}{*}{$\begin{array}{l}\text { Distance } \\
\text { to nearest } \\
\text { canal, } \\
\text { ditch, } \\
\text { or reservoir } \\
\text { (table 1; } \\
\text { feet) }\end{array}$} & \multirow{2}{*}{$\begin{array}{l}\text { Approximate } \\
\text { year of irrigation } \\
\text { removal and } \\
\text { gradient } \\
\text { direction } \\
\text { (appendix B) }\end{array}$} \\
\hline & & $\begin{array}{l}\text { Upgradient } \\
\text { acres/ } \\
\text { average } \\
\text { distance } \\
\text { (feet) }\end{array}$ & $\begin{array}{l}\text { Lateral } \\
\text { acres/ } \\
\text { average } \\
\text { distance } \\
\text { (feet) }\end{array}$ & $\begin{array}{l}\text { Downgradient } \\
\text { acres/ } \\
\text { average } \\
\text { distance } \\
\text { (feet) }\end{array}$ & & & \\
\hline 2 & 438 & $438 / 4,860$ & -- & -- & 1,200 & 1,000 & 1998- U \\
\hline 14 & 22 & -- & $22 / 1,200$ & -- & 1,000 & 165 & 1997- L \\
\hline 16 & 95 & $95 / 3,510$ & -- & -- & 3,300 & 400 & 1996 - U \\
\hline 21 & 98 & $98 / 4,700$ & -- & -- & 4,200 & 3,800 & Prior to 1987 - \\
\hline 31 & 215 & -- & $215 / 1,690$ & -- & 100 & 1,800 & 1995 -L \\
\hline 36 & 691 & $235 / 3,560$ & $456 / 5,350$ & -- & 600 & 75 & 2001 -U,L \\
\hline 37 & 1,000 & $187 / 5,560$ & $552 / 4,890$ & $261 / 6,800$ & 1,900 & 900 & $\begin{array}{l}\text { 1999-U, 2000-L, } \\
\text { 2000-D }\end{array}$ \\
\hline 38 & 1,000 & $187 / 5,560$ & $552 / 4,890$ & $261 / 6,800$ & 1,900 & ${ }^{1} 300$ & $\begin{array}{l}\text { 1999-U, 2000-L, } \\
\text { 2000-D }\end{array}$ \\
\hline 39 & 621 & $269 / 3,220$ & $318 / 2,540$ & $34 / 2,560$ & 200 & 126 & $\begin{array}{l}\text { 1996-U, 1991-L, } \\
1995-\mathrm{D}\end{array}$ \\
\hline 40 & 970 & $970 / 6,190$ & -- & -- & 1,400 & 1,000 & $2001-U$ \\
\hline 43 & 269 & -- & $269 / 5,390$ & -- & 3,000 & 145 & 2003 -L \\
\hline 44 & 269 & -- & $269 / 5,390$ & -- & 3,000 & 735 & 2003- L \\
\hline 45 & 842 & $545 / 5,480$ & $160 / 2,370$ & $137 / 4,040$ & 1,500 & 150 & $\begin{array}{l}\text { 1989-U, 2003-L, } \\
\text { 2000-D }\end{array}$ \\
\hline 46 & 545 & -- & -- & $545 / 3,570$ & 1,200 & 1,850 & 1989- D \\
\hline 47 & 545 & -- & -- & $545 / 3,570$ & 1,200 & 750 & 1989- D \\
\hline 50 & 230 & $230 / 2,200$ & -- & -- & 0 & 40 & 2003- U \\
\hline 60 & 255 & -- & $255 / 7,000$ & -- & 4,400 & 1,300 & 2003- L \\
\hline 62 & 1,001 & $416 / 2,860$ & $267 / 3,660$ & $318 / 3,940$ & 200 & 900 & $\begin{array}{l}\text { 2001-U, 2003-L } \\
\text { 1994-D }\end{array}$ \\
\hline 63 & 1,001 & $416 / 2,860$ & $270 / 3,660$ & $318 / 3,940$ & 200 & 63 & $\begin{array}{l}\text { 2001-U, 2003-L } \\
\text { 1994-DL }\end{array}$ \\
\hline 64 & 1,336 & $746 / 3,020$ & $115 / 3,190$ & $475 / 5,180$ & 200 & 13 & $\begin{array}{l}\text { 1999\&2001-U, } \\
\text { 1996-L, } \\
\text { 1992\&1996-D }\end{array}$ \\
\hline 65 & 315 & -- & -- & $315 / 4,040$ & 2,700 & 50 & 2003 -D \\
\hline 66 & 310 & $310 / 1,270$ & -- & -- & 200 & 20 & 2003 - D \\
\hline 70 & 1,265 & $478 / 4,110$ & $310 / 1140$ & $477 / 2,450$ & 20 & 272 & $\begin{array}{l}\text { 1996-U, 1997-L } \\
1994-\mathrm{D}\end{array}$ \\
\hline 71 & 1,265 & $1,265 / 8,820$ & -- & -- & 5,500 & 1,500 & 1996 - U \\
\hline 72 & 285 & $285 / 5,390$ & -- & -- & 3,700 & 200 & $2001-U$ \\
\hline
\end{tabular}

${ }^{1}$ Distance is to Stillwater Point Reservoir. 


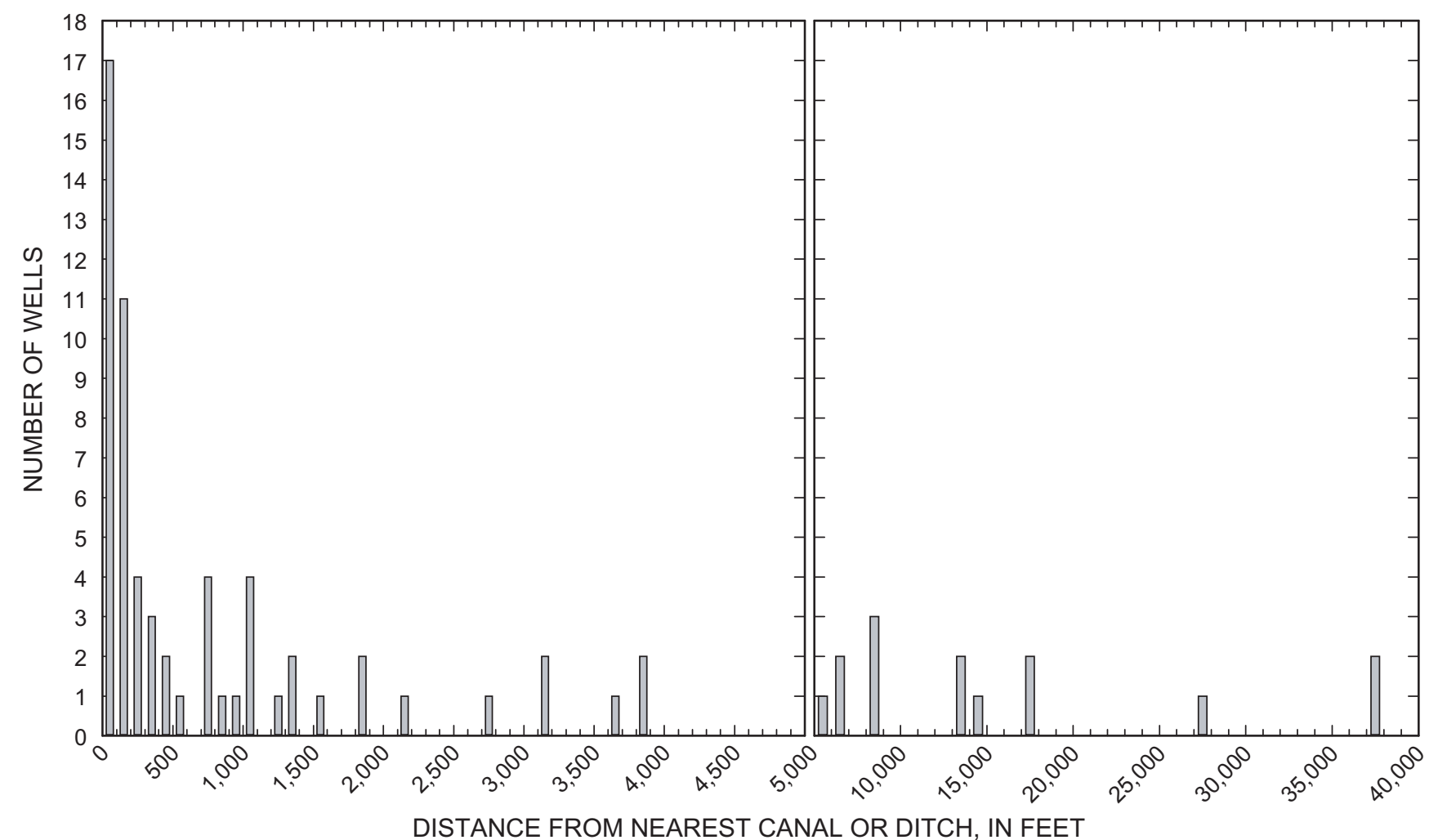

Figure 4. The distance of monitoring wells from active canals or ditches.

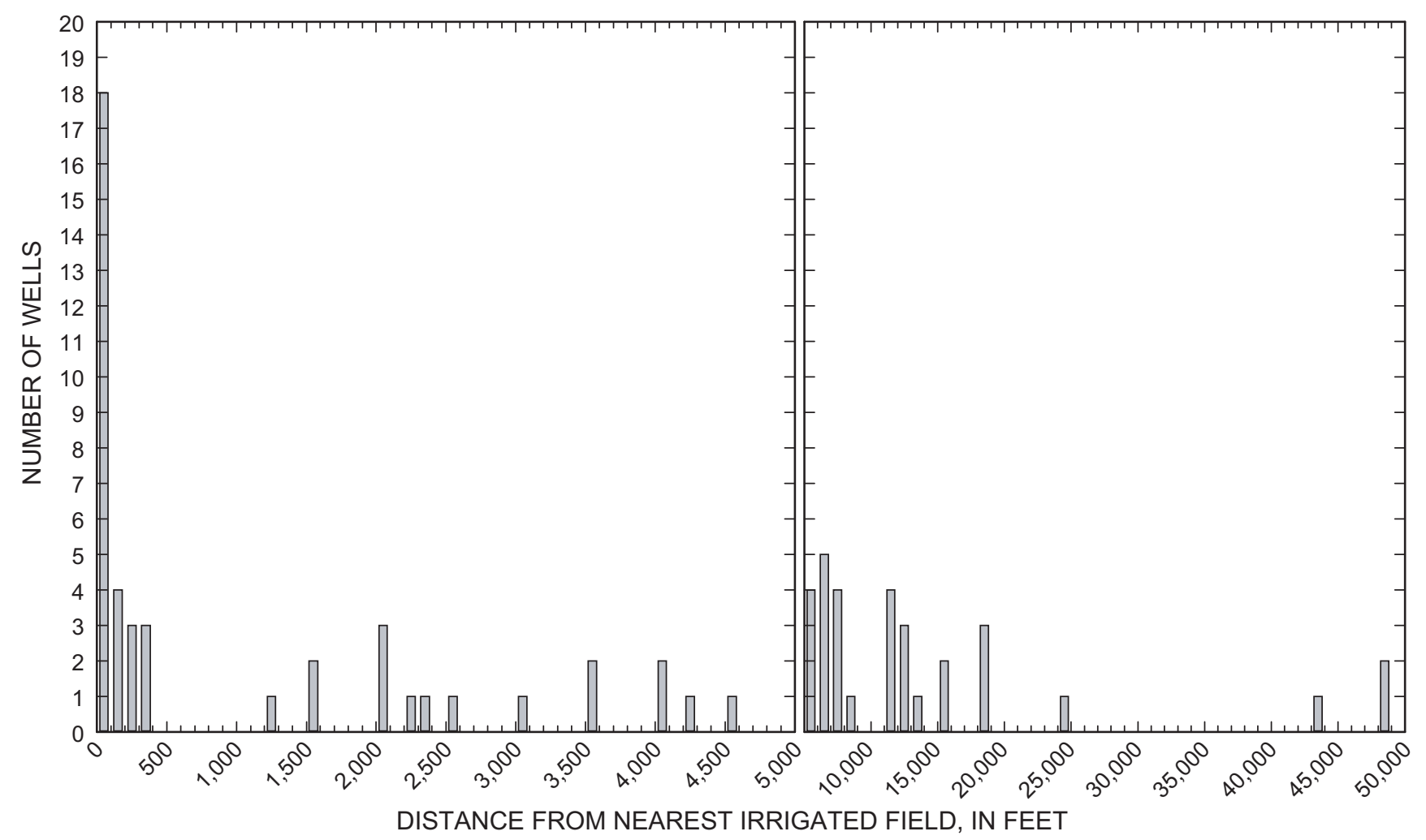

Figure 5. The distance of monitoring wells from irrigated land. 


\section{Evaluation of the Effects of Changes in Water Use}

\section{Changes in Ground-Water Levels}

The most likely effect of reducing the amount of irrigation water applied to fields would be declines in ground-water levels because recharge from infiltration beneath irrigated fields would decrease. Declining water levels also may be caused by other factors such as long-term variations in precipitation, ground-water pumping, or the short-term seasonal decrease in recharge from infiltration beneath canals and irrigated fields at the end of each irrigation season. These factors may be superimposed on each other and complicate the evaluation of the effects of changes in water use.

The timing and magnitude of seasonal water-level fluctuations have been previously studied by Glancy (1986) and Seiler and Allander (1993). Glancy (1986, p. 47) reported seasonal fluctuations of greater than $4 \mathrm{ft}$ in areas west of Fallon and south of Soda Lake in water years 1977-78, decreasing to 1 to $2 \mathrm{ft}$ northeast of Fallon and 1 to $3 \mathrm{ft}$ south of Fallon. For wells near irrigated areas, water levels were highest in June or July when releases from Lahontan Reservoir were greatest, and lowest near the end of the non-irrigation season in February to March (Glancy, 1986, p. 43-45). Water year 1977 was considered a drought year with releases from Lahontan Reservoir totaling about 220,000 acre-ft (fig 6). Seiler and Allander (1993, p. 14) reported seasonal water-level fluctuations of 1 to $2 \mathrm{ft}$ near irrigated areas in 1992, which was near the end of another longterm drought when releases from Lahontan Reservoir totaled only about 131,000 acre-ft (fig. 6). This suggests the magnitude of seasonal water-level fluctuations is related to the volume of surface water released from Lahontan Reservoir. Both studies noted greater seasonal fluctuations near irrigated areas than in areas distant from irrigation where seasonal water-level fluctuations are less than $1 \mathrm{ft}$.

Superimposed on seasonal fluctuations are more long-term changes in water levels caused by variations in annual precipitation in the headwaters of the Carson River. As shown by variations in the volume of water released from Lahontan Reservoir (fig. 6), dry conditions in 1977 were followed by a wet period in the early to mid-1980's, with a return to dry conditions from 1986 to 1994. From 1977 to 1992, water levels in Lahontan Valley rose an average of about $2 \mathrm{ft}$ in response to the wet period and declined from 1987 to 1992 an average of about $2.5 \mathrm{ft}$ (Seiler and Allander, 1993, p. 14). The net change measured from 1977 to 1992 was a median decline of $0.58 \mathrm{ft}$ (Seiler and Allander, 1993, p. 11).

After 1992, releases from Lahontan Reservoir increased to above average from 1995 through 1998, followed by below average releases from 2000 to 2003 (fig. 6). From 1992 to 1998, water levels rose between 2 and $5 \mathrm{ft}$ in most wells near irrigated areas, in response to increased releases from Lahontan Reservoir from 1995 to 1998 (app. C). In January 1997, flooding of the Carson River produced peak flows greater than any previously recorded (Thomas and Williams, 1997). In response to the four years of above average releases, water levels at many wells peaked during the middle of the irrigation season in 1997 or 1998 (app. C). Smaller rises or no changes were measured in wells that were distant from irrigation (for example, wells 8, 26, 59, 61, and 75; app. C).

The historical water-level measurements show that during periods of above average releases from Lahontan Reservoir, recharge from canal losses and infiltration of applied irrigation water creates an increase in ground-water storage that dissipates over time during subsequent periods of dry conditions. The latest period of dry conditions (2000-2003) corresponds to the time when water-level declines would be expected from reductions in irrigation on large parcels of land. Inspection of table 2 shows that irrigation was removed from large parcels from the late 1990's to 2003. This makes it difficult to distinguish the effects of drought from the effects of removing land from irrigation, and it will remain difficult until above average releases from Lahontan Reservoir occur again sometime in the future. At that time, water levels near parcels removed from irrigation may continue to decline or show little or no rise compared to those where irrigation has continued.

Because water levels at most wells near irrigated land have declined from 1998 to 2003, the effects of removing land from irrigation may be best shown by the difference between the greatest depth to water measured during 1992-95 and that measured during the same time of year during 2000-2003 (table 3). Negative values in table 3 indicate a water-level decline, and positive values indicate a water-level rise. Water-level differences from the mid 1970 's, the earlier period of dry conditions, to 2000-2003 for selected wells, also are included in table 3 for comparison. Water-level declines to depths greater than in 1992-95 ranged from 0.2 to $4.2 \mathrm{ft}$ at 11 wells near land removed from irrigation (fig. 3, table 3). Water-level declines were $1 \mathrm{ft}$ or less at 7 of the 11 wells but were $3.2,2.1$, and $4.2 \mathrm{ft}$ at wells, 62,70 , and 72, respectively, near the southern end of Lahontan Valley, and $1.2 \mathrm{ft}$ at well 2 on the western side of the valley (fig. 3 ). Water level declines from the mid-1970's to 2000-03 were 3.9 and $4.1 \mathrm{ft}$ at wells 70 and 72 , respectively. Given the decline of less than $1 \mathrm{ft}$ at the majority of the wells, it is uncertain if reductions in irrigation have significantly affected water levels in these wells.

At 14 wells near land removed from irrigation, water levels have risen 0.4 to $6.5 \mathrm{ft}$ compared to those in the early 1990's. Similarly, except for wells 7 and 20, water levels at 19 wells near continued irrigation did not change significantly, or have risen 0.2 to $5.1 \mathrm{ft}$ (table 3 ). The water-level rises near continued irrigation may indicate that dry conditions in the early 1990's were more severe than those in 2003. Water deliveries for irrigation in 1992 and 1994 were less than the normally allotted volumes, while deliveries in 2003 were 100 percent of normal (David Overvold, Truckee-Carson Irrigation District, oral commun., 2004). 
Table 3. Changes in water levels at selected wells from the early 1990's and mid-1970's to 2003.

[Positive values indicate water-level rise, negative values indicate water-level decline]

\begin{tabular}{|c|c|c|c|c|c|c|c|}
\hline \multicolumn{4}{|c|}{ Wells near land removed from irrigation } & \multicolumn{4}{|c|}{ Wells near continued irrigation } \\
\hline $\begin{array}{c}\text { Site } \\
\text { number } \\
\text { (figure 3) }\end{array}$ & $\begin{array}{l}\text { Water } \\
\text { level } \\
\text { date }\end{array}$ & $\begin{array}{l}\text { Depth to } \\
\text { water } \\
\text { (feet) }\end{array}$ & $\begin{array}{l}\text { Water-level } \\
\text { difference } \\
\text { (feet) }\end{array}$ & $\begin{array}{c}\text { Site } \\
\text { number } \\
\text { (figure 3) }\end{array}$ & $\begin{array}{l}\text { Water } \\
\text { level } \\
\text { date }\end{array}$ & $\begin{array}{l}\text { Depth } \\
\text { to } \\
\text { water } \\
\text { (feet) }\end{array}$ & $\begin{array}{c}\text { Water-level } \\
\text { difference } \\
\text { (feet) }\end{array}$ \\
\hline 2 & $\begin{array}{l}09 / 10 / 03 \\
09 / 21 / 95\end{array}$ & $\begin{array}{l}11.70 \\
10.46\end{array}$ & -1.2 & 3 & $\begin{array}{l}03 / 17 / 03 \\
03 / 22 / 93\end{array}$ & $\begin{array}{l}12.21 \\
12.25\end{array}$ & 0.0 \\
\hline 14 & $\begin{array}{l}03 / 17 / 03 \\
03 / 11 / 93\end{array}$ & $\begin{array}{l}10.07 \\
11.84\end{array}$ & 1.8 & 6 & $\begin{array}{l}10 / 07 / 03 \\
10 / 24 / 92\end{array}$ & $\begin{array}{l}12.59 \\
14.00\end{array}$ & 1.4 \\
\hline 16 & $\begin{array}{l}12 / 12 / 02 \\
11 / 27 / 92\end{array}$ & $\begin{array}{l}4.76 \\
7.17\end{array}$ & 2.4 & 7 & $\begin{array}{l}05 / 16 / 03 \\
05 / 05 / 93\end{array}$ & $\begin{array}{l}26.95 \\
25.63\end{array}$ & -1.3 \\
\hline 21 & $\begin{array}{l}09 / 08 / 03 \\
09 / 29 / 93\end{array}$ & $\begin{array}{l}20.58 \\
19.79\end{array}$ & -.8 & 7 & $\begin{array}{l}04 / 03 / 03 \\
04 / 03 / 78\end{array}$ & $\begin{array}{l}26.71 \\
23.49\end{array}$ & -3.2 \\
\hline 31 & $\begin{array}{l}10 / 07 / 03 \\
09 / 29 / 93\end{array}$ & $\begin{array}{r}10.00 \\
9.60\end{array}$ & -.4 & 9 & $\begin{array}{l}04 / 02 / 03 \\
04 / 17 / 93\end{array}$ & $\begin{array}{l}8.27 \\
9.73\end{array}$ & 1.5 \\
\hline 36 & $\begin{array}{l}05 / 15 / 03 \\
06 / 11 / 92\end{array}$ & $\begin{array}{l}3.85 \\
6.67\end{array}$ & 2.8 & 10 & $\begin{array}{l}09 / 10 / 03 \\
09 / 07 / 93\end{array}$ & $\begin{array}{l}16.42 \\
16.45\end{array}$ & 0 \\
\hline 37 & $\begin{array}{l}09 / 10 / 03 \\
09 / 27 / 93\end{array}$ & $\begin{array}{l}6.43 \\
8.57\end{array}$ & 2.1 & 10 & $\begin{array}{l}09 / 10 / 03 \\
09 / 16 / 76\end{array}$ & $\begin{array}{l}16.42 \\
14.79\end{array}$ & -1.6 \\
\hline 38 & $\begin{array}{l}12 / 13 / 02 \\
11 / 04 / 92\end{array}$ & $\begin{array}{r}6.96 \\
12.00\end{array}$ & 5.0 & 11 & $\begin{array}{l}01 / 27 / 03 \\
01 / 23 / 93\end{array}$ & $\begin{array}{r}9.48 \\
12.94\end{array}$ & 3.5 \\
\hline 39 & $\begin{array}{l}04 / 03 / 03 \\
04 / 17 / 93\end{array}$ & $\begin{array}{l}4.81 \\
9.45\end{array}$ & 4.6 & 15 & $\begin{array}{l}12 / 12 / 02 \\
11 / 27 / 92\end{array}$ & $\begin{array}{l}7.24 \\
9.95\end{array}$ & 2.7 \\
\hline 40 & $\begin{array}{l}09 / 24 / 01 \\
03 / 19 / 93\end{array}$ & $\begin{array}{r}9.24 \\
10.78\end{array}$ & 1.5 & 17 & $\begin{array}{l}03 / 17 / 03 \\
03 / 22 / 93\end{array}$ & $\begin{array}{r}7.81 \\
10.06\end{array}$ & 2.3 \\
\hline 43 & $\begin{array}{l}09 / 10 / 03 \\
12 / 01 / 94\end{array}$ & $\begin{array}{l}6.12 \\
7.01\end{array}$ & .9 & 18 & $\begin{array}{l}04 / 03 / 03 \\
04 / 17 / 93\end{array}$ & $\begin{array}{l}15.66 \\
16.21\end{array}$ & 6 \\
\hline 44 & $\begin{array}{l}12 / 13 / 02 \\
11 / 28 / 92\end{array}$ & $\begin{array}{l}5.81 \\
7.77\end{array}$ & 2.0 & 20 & $\begin{array}{l}09 / 08 / 03 \\
09 / 11 / 92\end{array}$ & $\begin{array}{l}30.06 \\
28.97\end{array}$ & -1.1 \\
\hline 45 & $\begin{array}{l}10 / 07 / 03 \\
10 / 10 / 92\end{array}$ & $\begin{array}{l}3.45 \\
9.98\end{array}$ & 6.5 & 20 & $\begin{array}{l}09 / 08 / 03 \\
08 / 09 / 78\end{array}$ & $\begin{array}{l}30.06 \\
26.86\end{array}$ & -3.2 \\
\hline 46 & $\begin{array}{l}03 / 17 / 03 \\
02 / 22 / 92\end{array}$ & $\begin{array}{l}9.63 \\
9.28\end{array}$ & -.4 & 32 & $\begin{array}{l}03 / 17 / 03 \\
03 / 18 / 93\end{array}$ & $\begin{array}{r}9.67 \\
12.94\end{array}$ & 3.3 \\
\hline 47 & $\begin{array}{l}10 / 07 / 03 \\
01 / 23 / 93\end{array}$ & $\begin{array}{l}9.78 \\
9.51\end{array}$ & -.3 & 42 & $\begin{array}{l}09 / 10 / 03 \\
09 / 15 / 92\end{array}$ & $\begin{array}{l}3.46 \\
3.67\end{array}$ & .2 \\
\hline 50 & $\begin{array}{l}09 / 09 / 03 \\
09 / 11 / 92\end{array}$ & $\begin{array}{l}7.17 \\
6.60\end{array}$ & -.6 & 52 & $\begin{array}{l}03 / 17 / 03 \\
03 / 18 / 93\end{array}$ & $\begin{array}{l}7.05 \\
9.19\end{array}$ & 2.1 \\
\hline 60 & $\begin{array}{l}09 / 09 / 03 \\
08 / 03 / 94\end{array}$ & $\begin{array}{l}12.26 \\
12.04\end{array}$ & -.2 & 53 & $\begin{array}{l}03 / 17 / 03 \\
03 / 18 / 93\end{array}$ & $\begin{array}{l}7.87 \\
9.65\end{array}$ & 1.8 \\
\hline 62 & $\begin{array}{l}08 / 22 / 03 \\
11 / 27 / 92\end{array}$ & $\begin{array}{r}12.92 \\
9.77\end{array}$ & -3.2 & 54 & $\begin{array}{l}09 / 10 / 03 \\
09 / 29 / 92\end{array}$ & $\begin{array}{r}6.85 \\
11.94\end{array}$ & 5.1 \\
\hline 63 & $\begin{array}{l}10 / 07 / 03 \\
11 / 27 / 92\end{array}$ & $\begin{array}{l}-1.30 \\
-0.59\end{array}$ & .7 & 56 & $\begin{array}{l}10 / 07 / 03 \\
10 / 24 / 92\end{array}$ & $\begin{array}{l}6.70 \\
9.95\end{array}$ & 3.3 \\
\hline 64 & $\begin{array}{l}10 / 07 / 03 \\
11 / 18 / 94\end{array}$ & $\begin{array}{l}8.17 \\
8.53\end{array}$ & .4 & 57 & $\begin{array}{l}12 / 12 / 02 \\
11 / 27 / 92\end{array}$ & $\begin{array}{r}7.84 \\
11.57\end{array}$ & 3.7 \\
\hline 65 & $\begin{array}{l}09 / 03 / 03 \\
09 / 28 / 92\end{array}$ & $\begin{array}{l}3.19 \\
6.59\end{array}$ & 3.4 & 58 & $\begin{array}{l}04 / 02 / 03 \\
04 / 17 / 93\end{array}$ & $\begin{array}{r}8.44 \\
10.33\end{array}$ & 1.9 \\
\hline 66 & $\begin{array}{l}10 / 15 / 03 \\
10 / 24 / 92\end{array}$ & $\begin{array}{l}5.82 \\
7.18\end{array}$ & 1.4 & 67 & $\begin{array}{l}03 / 17 / 03 \\
02 / 27 / 93\end{array}$ & $\begin{array}{r}7.80 \\
10.12\end{array}$ & 2.3 \\
\hline 70 & $\begin{array}{l}04 / 02 / 03 \\
04 / 18 / 92\end{array}$ & $\begin{array}{l}8.41 \\
6.30\end{array}$ & -2.1 & & & & \\
\hline 70 & $\begin{array}{l}04 / 02 / 03 \\
04 / 09 / 76\end{array}$ & $\begin{array}{l}8.41 \\
4.49\end{array}$ & -3.9 & & & & \\
\hline 71 & $\begin{array}{l}09 / 10 / 03 \\
07 / 22 / 93\end{array}$ & $\begin{array}{l}8.49 \\
7.98\end{array}$ & -.5 & & & & \\
\hline 72 & $\begin{array}{l}05 / 14 / 03 \\
10 / 20 / 95\end{array}$ & $\begin{array}{l}25.40 \\
21.23\end{array}$ & -4.2 & & & & \\
\hline 72 & $\begin{array}{l}05 / 14 / 03 \\
05 / 19 / 76\end{array}$ & $\begin{array}{l}25.4 \\
21.29\end{array}$ & -4.1 & & & & \\
\hline
\end{tabular}




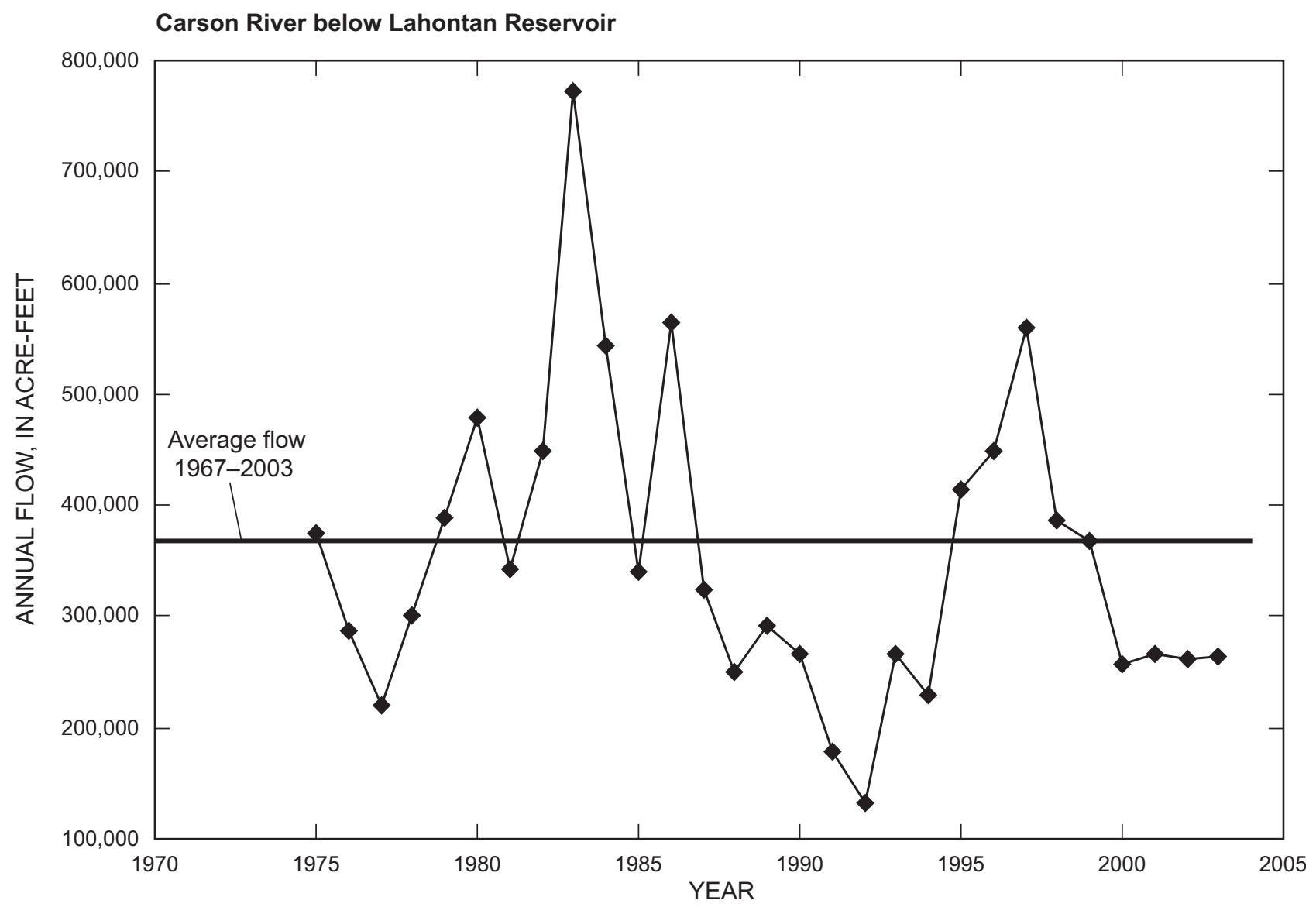

Figure 6. Annual volume of water released from Lahontan Reservoir, 1967-2003.

Water levels at wells 7, 10, and 20 near continued irrigation show long-term decline from the late 1970's (table 3, app. C). From the mid 1970's to 2000-2003, water levels declined $3.2 \mathrm{ft}$ at well $7,1.6 \mathrm{ft}$ at well 10, and $3.2 \mathrm{ft}$ at well 20; however, these wells are not near land removed from irrigation. The decline at well 7, screened about $140 \mathrm{ft}$ below land surface, may have been caused by nearby industrial pumping from wells screened and gravel-packed from 100 to $190 \mathrm{ft}$ below land surface and installed in 1997 and 2000 (K. Bernard, SMI Joist; K. Balnini, Wheeling Corrugating, oral communs., 2003). This is likely because water levels at nearby well 6 , screened from 23 to $28 \mathrm{ft}$, rose from 1992 to 2003 (table 3, app. A and C). Declines at wells 10 and 20 may have been caused by the discontinued use of nearby reservoirs, Sheckler and Old River, in about 1998 and 1990, respectively (fig. 3; David Overvold, Truckee-Carson Irrigation District, oral commun., 2003). Wells 10 and 20 are about $1 \mathrm{mi}$ from the reservoirs where use was discontinued.

Simple linear regressions were developed to determine if a statistically-significant relation existed between water-level decline and the acreage removed from irrigation, or the distance from acreage removed. The dependent variables used in the regressions were water-level change for the 25 wells within a mile of land removed from irrigation, and water-level change for only the 11 wells that showed a water-level decline. The independent variables were the total acreage removed from irrigation in all directions; the acreage removed from irrigation upgradient of the well; the minimum and average distance from land removed from irrigation; and the total acreage in all directions and upgradient acreage removed, multiplied by both the minimum and average distance of the acreage. All regressions resulted in poor relations with coefficients of determination $\left(\mathrm{R}^{2}\right)$ of 0.03 or less.

It is likely that seepage from the extensive network of canals and ditches throughout Lahontan Valley effectively masks the effects of reductions in irrigation. To test this hypothesis, water-level change for all wells was regressed against canal distance, regardless of canal direction (fig. 7). This also results in a poor relation. However, figure 7 shows that most wells with declining water levels are more than $300 \mathrm{ft}$ from the nearest canal. Canal distance may have a greater influence on the measured water-level changes than the acreage or distance of land removed from irrigation. In addition to these factors, the few number of wells (12) more than $300 \mathrm{ft}$ from active canals, yet near reductions in irrigation does not allow development of meaningful relations between water-level decline and the acreage of, or distance from, land removed from irrigation. 


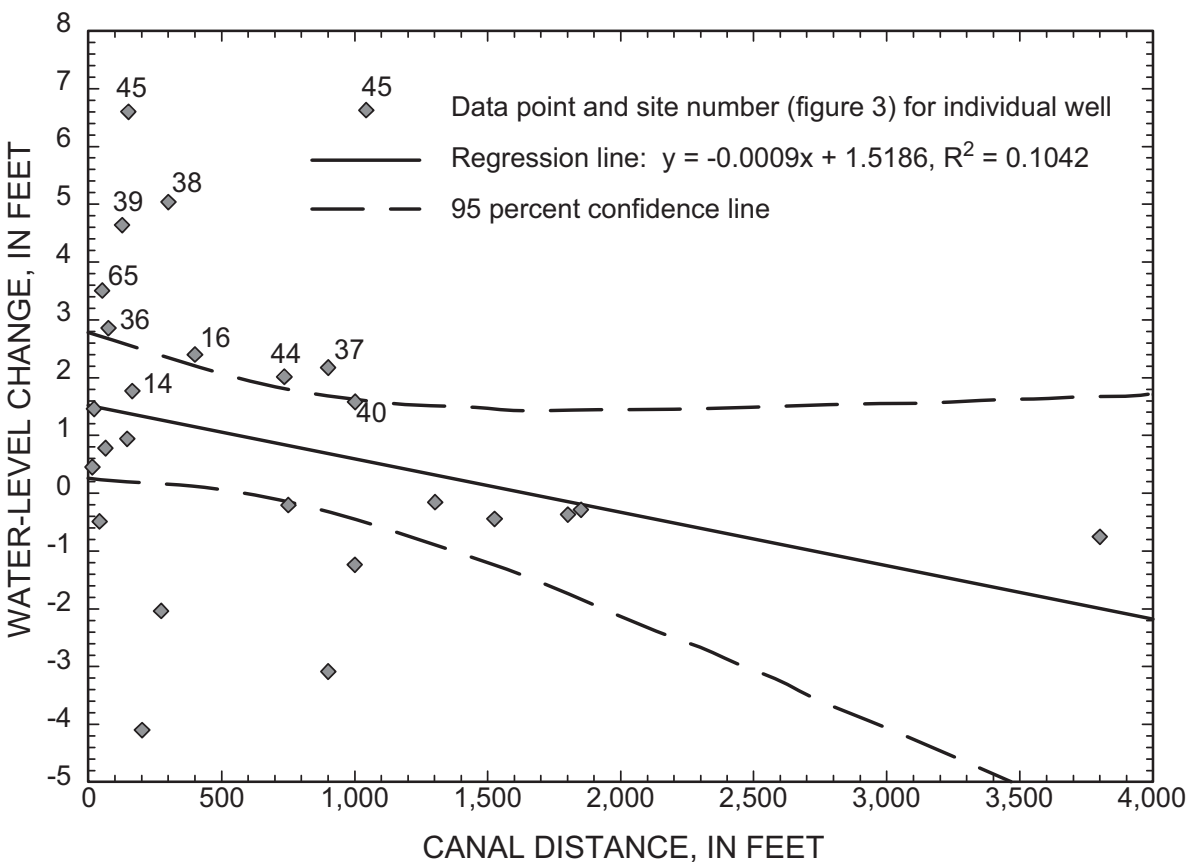

Figure 7. Relation between water-level change between 1992-95 and 2003 and distance from canals. Positive values indicate water-level rise, negative values indicate water-level decline. Numbers near points showing more than about 2 feet of waterlevel rise are site numbers, figure 3 .
Although no simple relation can be developed directly from the data, the general observation can be made that for wells near reductions in irrigation, water-level declines are greatest at wells distant from continued irrigation and active canals and near canals with decreased use. The three greatest water-level declines were measured at wells 62, 70, and 72 (table 3). Wells 62 and 70 are surrounded by more than 1,000 acres of land removed from irrigation, and water levels at well 72 also may be affected by the upgradient removal of irrigation from 1,270 acres of land surrounding well 70 (fig. 3). Wells 62, 70 , and 72 are $3,600 \mathrm{ft}$ or more from the nearest field that continues to be irrigated. Two wells, 70 and 72, are within $300 \mathrm{ft}$ of a canal (table 1); however, surface-water deliveries in the canal decreased from about 1,500 acre-ft in 1998 to only about 50 acre-ft in 2002 (David Overvold, Truckee-Carson Irrigation District, written commun., 2003).

Figure 7 also shows that most wells with water-level rises of greater than about $2 \mathrm{ft}$ are less than $300 \mathrm{ft}$ from canals. Many of the wells with water-level rises are near Stillwater, Nev. (fig. 3). Although several wells near Stillwater (wells 36-40 and 43-47) are near large areas removed from irrigation, water levels have risen in most wells and declined small amounts $(<1 \mathrm{ft})$ at only two wells (46 and 47; table 3 ). Many of these wells are located near fields that continue to be irrigated, or are within $300 \mathrm{ft}$ of the nearest canal. Flow and surface stage have increased in canals delivering water to wetland areas near Stillwater (David Overvold, Truckee-Carson Irrigation District, written and oral commun., 2003). Increased flow and surface stage likely has increased the seepage from the canals, causing water-level rises in the wells even though land near them was removed from irrigation.

\section{Changes in Ground-Water Quality}

Herrera and others (2000) used a conceptual model of ground-water flow in the shallow aquifer to evaluate potential effects of changing irrigation practices in the Fallon area. They concluded that if water deliveries to lateral canals remain unchanged, irrigation reduction is likely to lower the average salinity of the shallow ground water. Removing canals from service will decrease seepage from canals, which likely will cause dissolved solids concentrations to increase in ground water for which canal seepage is a principal source of recharge. These conclusions were based on the fact that recharge from water applied to fields for irrigation adds more salt to the ground water than recharge from canal loss. This is because canal seepage is only slightly affected by evaporation whereas most water applied to fields is consumed by evapotranspiration, causing the dissolved-solids concentration to increase in the water that infiltrates to the water table.

For these reasons, it is reasonable to assume that changes in water use in Lahontan Valley likely will cause changes in water quality in the shallow aquifer. However, the distinct change in the stable-isotopic composition of water at a depth of $50 \mathrm{ft}$, discussed previously (see section titled "Physical and Hydrologic Setting"), shows that surface water applied during operation of the Newlands Project has not infiltrated to depths of more than $50 \mathrm{ft}$ near the center of Lahontan Valley. Thus, the water chemistry of the intermediate aquifer has not been affected by the profound change in water use after widespread irrigation began in Lahontan Valley nearly 90 years ago. This indicates that it is unlikely that changes in irrigation practices will have an effect on water quality in the intermediate aquifer near the center of Lahontan Valley. 
Five wells (14, 31, 39, 50, and 64; fig. 3) have been monitored since the late 1990's to evaluate long-term changes in water quality, and two wells (12 and 13) have been monitored since 2000 (app. A and D). The five wells were previously sampled after installation in the late 1980's. Plots of specific conductance were used to evaluate changes in water quality because it is related to the salinity of the water. Decreases in specific conductance will correspond with decreases in the salt content of the ground water (fig. 8). Laboratory values were generally used rather than field values because they were considered more accurate and, in some cases, field measurements from a flow-through chamber were not available.

Well 14 shows strong seasonal changes in water level and water quality (app. C; fig. 8). It is unlikely that water quality has changed in the well as a result of changes in water use; only 22 acres of land were removed from irrigation and they were more than $1,000 \mathrm{ft}$ from the well (table 2). Well 14 is near a major canal delivering water to the southern part of the study area. The low specific conductance values occur during the irrigation season (app. D, fig. 8) and likely reflect seepage losses of relatively fresh water from the canal. The high conductance samples generally are associated with high nitrate concentrations (app. D). Since the well is near a house, the high nitrate could originate from septic system effluent that is diluted by canal seepage during summer months.

Wells 31 and 50 show relatively small decreases in specific conductance that follow changes in water use. Water-quality data are not available for these wells for the period shortly before and after land was removed from irrigation. For this reason, it is uncertain whether the improvement in water quality is due to changes in irrigation or some other factor(s).

Wells 39 and 64 show large changes in specific conductance (fig. 8) that may be related to changes in water use. In both of these wells, there was a large decline in the amount of sodium, chloride, and sulfate following removal of irrigation from nearby land (app. D). Because most water applied for irrigation is consumed by evapotranspiration, these changes are consistent with reduced irrigation. A large decline in specific conductance in well 39 occurred following removal of about 260 acres of land, a minimum distance of $200 \mathrm{ft}$ from the well in 1995 and 1996 (fig. 8; table 2). In addition, starting about 2000 , increased flows and surface stage in a nearby canal used for delivery of water to wetlands, probably resulted in greater seepage of low conductance water to the shallow aquifer. A decrease in specific conductance in well 64 was more than tenfold. It is uncertain, however, whether this can be associated with the removal of about 300 acres of land from irrigation near the well in 1992, and about 800 acres of land from 1994 to 1999 , because few data are available near the time when the change occurred.

Wells 12 and 13 show only slight changes in specific conductance over the last three years. These wells are in a suburban area and were drilled to monitor changes in water quality attributable to urbanization. At present (2003), too little data are available to assess trends in water quality.
Changes in water quality are occurring in areas where changes would be expected on the basis of recorded changes in water use. Although the changes in ionic composition of the water are consistent with what would be expected, the available data are not sufficient to conclusively demonstrate that the changes resulted from reductions in application of irrigation water. Few data are available for periods near the time of changes in water use; therefore, it is difficult to evaluate whether changes in water use and changes in water quality are temporally associated.

\section{Suggestions for Improvement of the USGS Monitoring-Well Network}

Wells where continued monitoring is considered useful are shown in figure 9. An evaluation of the monitoring-well network shows that 32 wells are less than $300 \mathrm{ft}$ from an active canal or ditch, and thus likely can be useful for detecting waterlevel changes caused by reductions in flow or discontinued use of the canals. However, flow in most canals has not been significantly reduced over much of Lahontan Valley even after removal of about 9,800 acres of land from irrigation.

Monitoring of all wells in irrigated areas, except those extremely close $(<50 \mathrm{ft}$ ) to canals, would provide useful background and comparison data on water-level changes caused by long-term changes in releases from Lahontan Reservoir. Twenty-five monitoring wells are within about $1 \mathrm{mi}$ of a field removed from irrigation. Continued measurements on all 25 wells near fields removed from irrigation may show if water levels eventually begin to decline. Twelve of those 25 wells also are more than $300 \mathrm{ft}$ from a canal, and an additional 5 wells are near currently irrigated fields but are also more than $300 \mathrm{ft}$ from a canal. Those 17 wells (shaded in tables 1 and 2) would provide the most useful data for determining the effects of removing fields from irrigation. Continued monitoring of wells near Carson Lake (wells 68 and 69) where water deliveries may increase and wells showing declines from discontinued use of reservoirs (wells 10 and 20) would be useful.

The number of monitoring wells in areas distant from irrigated fields, such as wells 24-27 (fig. 9), could be reduced without sacrificing the ability of the network to detect water-level and water-quality changes caused by changes in water use. In all, monitoring of 23 wells could be discontinued. This would allow available funds to be spent on installing wells in more useful locations.

Additional wells located as near as possible, or even within currently irrigated fields where reductions in irrigation will likely occur, yet more than $300 \mathrm{ft}$ from irrigation canals or ditches would provide an expanded data set to better evaluate the effect of water-use changes on water levels. Consultation with USFWS and other agencies purchasing water rights would allow locations for new wells to be selected and water-level measurements and water-quality sampling to begin before changes in water use are implemented. Data collection could begin while irrigation is still maintained with frequent, perhaps monthly, measurements of water levels and specific conductance following reductions in irrigation. 


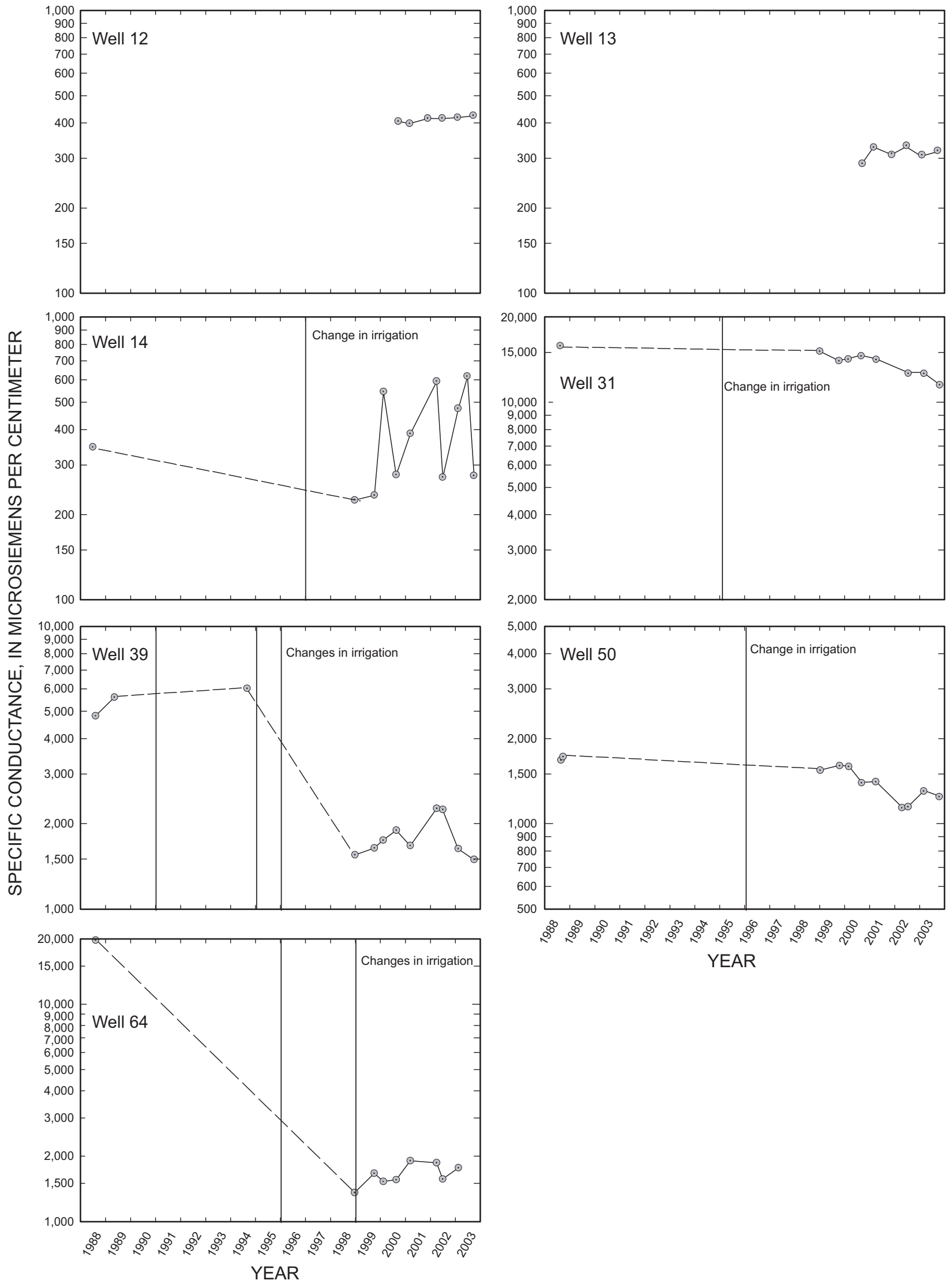

Figure 8. Changes in specific conductance at selected wells, 1988-2003. 


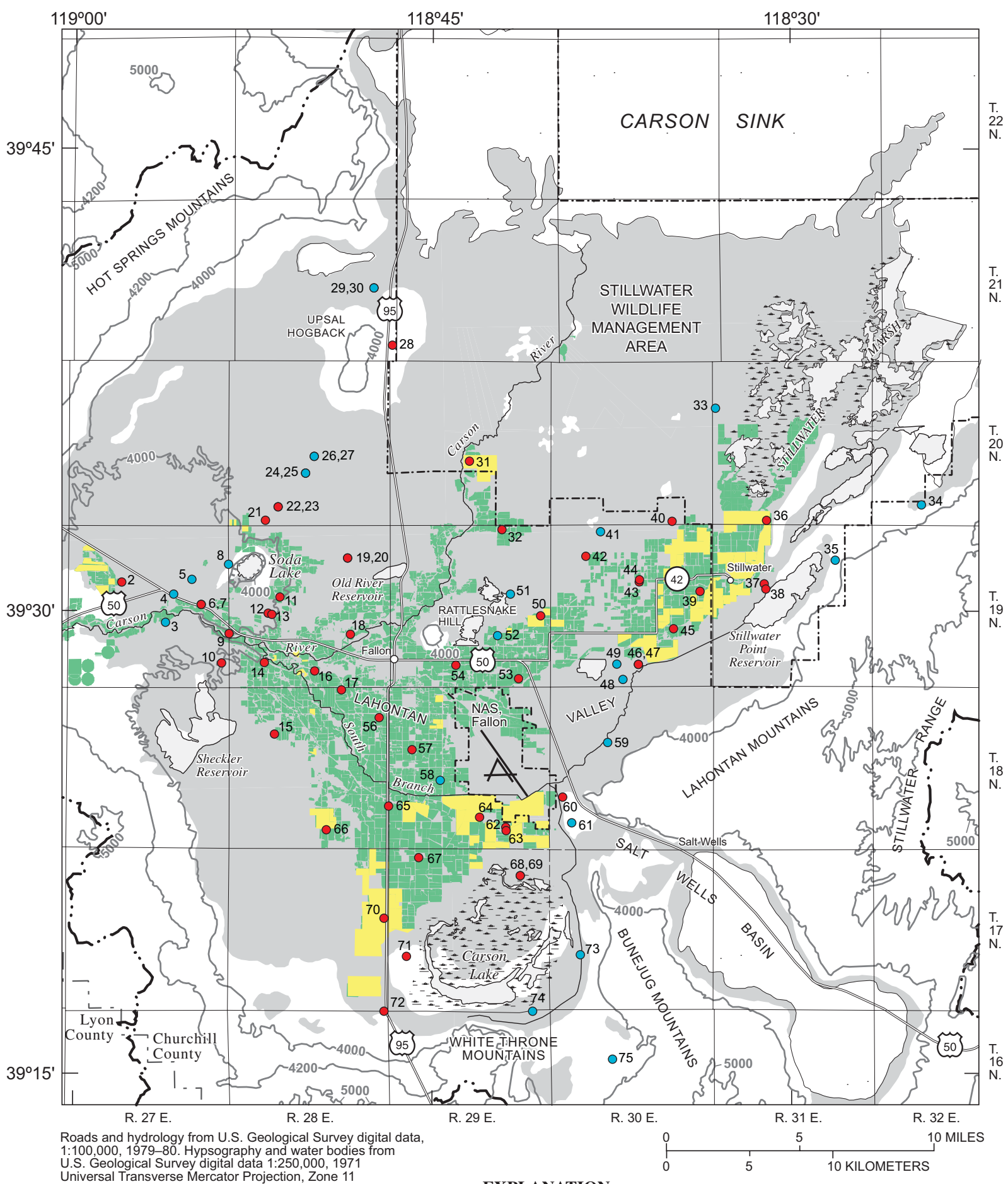

EXPLANATION

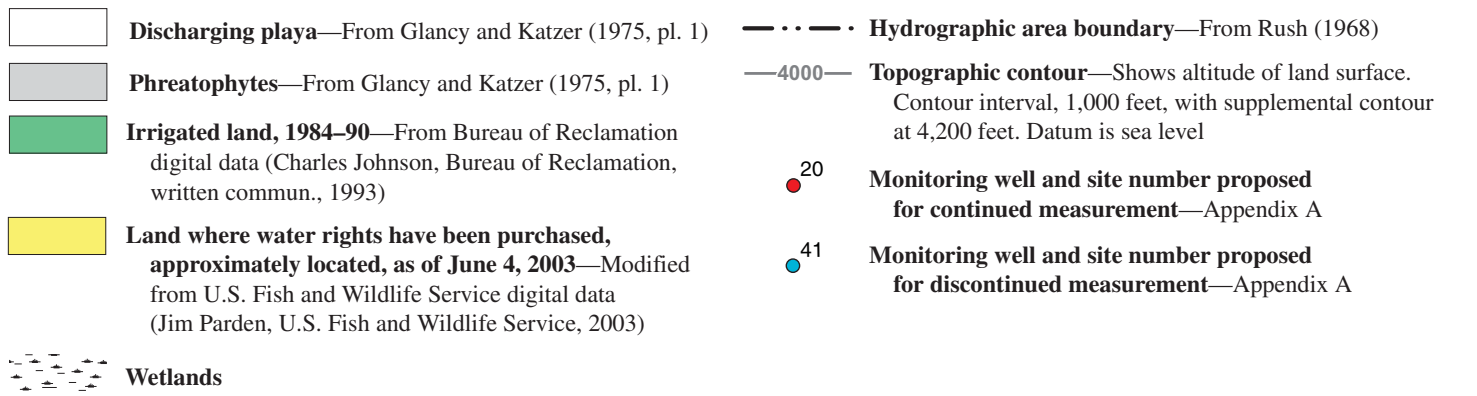

Figure 9. Location of monitoring wells where continued monitoring would be useful, and where monitoring could be discontinued. 


\section{Summary and Conclusions}

Because domestic wells tapping shallow ground water are an important source of potable water for rural residents of Lahontan Valley, the public has expressed concern over the acquisition of water rights for wetland areas in Carson Desert as directed by Public Law 101-618. Removal of land from irrigation and delivery of water to the wetland areas could cause shallow domestic wells to go dry and adversely affect shallow ground-water quality. In cooperation with Churchill County, periodic water-level measurements were made from 1992 to 2003 at 75 wells and water-quality samples were collected from 5 wells from 1998 to 2003 and 2 wells from 2000 to 2003. The purpose of the data collection was to obtain necessary data to evaluate the potential effects of changes in water use. In 2003, the USGS began an evaluation of the monitoring-well network. The purpose of the evaluation was to determine if the location and distribution of monitoring wells provide a reasonable means to measure the response of the shallow aquifer to changes in water use, and to determine if measurable changes in water levels and water quality have taken place.

Monitoring wells were characterized in terms of distance from active irrigation canals or ditches, and distance from currently (2003) or formerly irrigated land. Measurements on the ground and measurements from aerial photographs were used to determine the distance between the wells and canals and irrigated land. Maps, files, and aerial photographs from the U.S. Fish and Wildlife Service, the Bureau of Reclamation, and the Truckee-Carson Irrigation District were used to determine which network wells are near land where water-rights have been purchased as of June 2003, the irrigation history on those parcels from 1992 to 2003, and the flow of water in nearby canals.

Of the 75 wells in the network, 32 wells are within $300 \mathrm{ft}$ of canals and likely would not be useful to detect changes from reductions in irrigation applications because seepage from the canals maintains relatively stable water levels. These 32 wells would be useful to measure water-level changes from reductions in flow or discontinued use of individual canals. Twentyeight of the wells are within $400 \mathrm{ft}$ of irrigated land. However, 20 of these wells also are within $300 \mathrm{ft}$ of a canal and likely not useful to detect future (after 2003) reductions in irrigation. Wells in the range of 400 to $1,200 \mathrm{ft}$ from irrigated land are lacking, and wells greater than 1,200 ft from an irrigated field may be too distant to detect the effects of reductions in irrigation. Thus, the current network only has eight wells that are likely to be useful for detecting the effects of future (after 2003) reductions in irrigation.

Purchases of water rights for use in wildlife areas has resulted in about 9,800 acres of fields being removed from irrigation, with the bulk being removed from the late 1990's to 2003. Of the 75 wells in the network, 25 are within about $1 \mathrm{mi}$ of a field removed from irrigation. Near the 25 wells, areas ranging from about 20 acres of land to almost 1,500 acres were removed from irrigation. Of the 25 wells, 13 are within $300 \mathrm{ft}$ of canals and likely will not be useful for detecting changes in water levels caused by reductions in irrigation. The remaining 12 wells range from about 400 to $3,800 \mathrm{ft}$ from the nearest canal and may be useful for detecting changes in water levels caused by current (2003) changes in water use.

The most likely effect of changes in water use caused by removing land from irrigation would be a decline in groundwater levels because recharge from infiltration beneath irrigated fields is decreased. Declining water levels also may have been caused by long-term variations in the amount of water released from Lahontan Reservoir. Historically, releases were generally below normal for 1976-78, 1987-94, and 2000-2003, and were above normal for 1982-86 and 1995-98. Water-level measurements from the mid-1970's to 2003 show that during wet conditions, characterized by above average releases from Lahontan Reservoir, recharge from increased infiltration causes an increase in ground-water storage that dissipates over time during the subsequent dry conditions.

Because water levels at most wells near irrigated land have declined from 1998-2002, the effects of removing land from irrigation may be best shown by water-level declines between the last two periods of dry conditions and below normal releases from Lahontan Reservoir, 1992-95 and 2000-2003. At 11 of the 25 wells within about $1 \mathrm{mi}$ of land removed from irrigation, water-levels declined from 0.2 to $4.2 \mathrm{ft}$ between these periods. Water level declines were about $1 \mathrm{ft}$ or less at eight of the wells but were 2 to $4 \mathrm{ft}$ at three wells in the southern part of Lahontan Valley. Given the small amount of decline at most of the wells, it is uncertain if reductions in irrigation have affected water levels in these wells.

In 15 of the 19 wells in areas where irrigation practices did not change, water levels rose between 0.2 and $5.1 \mathrm{ft}$ between 1992-95 and 2000-2003. This suggests that dry conditions in the early 1990's were more severe than those in 2003. At the remaining three wells, water levels declined 1.6 to $3.2 \mathrm{ft}$ from the mid-1970's and 1990's to 2003. The decline at one well was likely caused by nearby industrial pumping, and the declines at the other two wells may have been caused by discontinued use of reservoirs about $1 \mathrm{mi}$ from the wells.

Water-level declines from 1998 to 2003 because of below normal releases from Lahontan Reservoir coincide with the period of irrigation reductions, tending to mask declines directly caused by the reductions. It is likely that seepage from the diffuse network of canals and ditches in Lahontan Valley also masks declines caused by reductions in irrigation. In addition, the limited number of monitoring wells near land removed from irrigation, yet more than 300 feet from an active canal, does not allow a statistical correlation between reductions in irrigation and water-level declines.

The maximum observed water declines were measured in three wells near or surrounded by more than 1,000 acres removed from irrigation, more than $3,600 \mathrm{ft}$ from continued irrigation, and within $300 \mathrm{ft}$ of a canal with greatly decreased use. Water-levels generally rose in monitoring wells near Stillwater, 
Nev., even though large amounts of nearby land were removed from irrigation. This was likely caused by conditions in 2003 that were not as dry as those in the early 1990's and additional seepage from the increased use and stage of canals for delivery of water to wetland areas.

Five wells have been monitored since the late 1990's and two wells have been monitored since 2000 to evaluate longterm changes in water quality. Plots of specific conductance were used to evaluate changes in water quality. Wells 39 and 64 show large changes in specific conductance that may be related to changes in water use. The decline in specific conductance in well 39 followed removal of about 260 acres of land a minimum distance of $200 \mathrm{ft}$ from the well in 1995 and 1996, and increased flows and surface stage in a nearby canal in 2000. A decrease in specific conductance in well 64 was more than tenfold. However, it is uncertain if the cause was related to changes in water use due to the lack of samples near the time when about 1,100 acres were removed from irrigation near the well from 1992 to 1999. Two wells, 31 and 50, show relatively small decreases in specific conductance that follow changes in water use. Whether the improvement in water quality is due to changes in irrigation or some other factor(s) is uncertain because water-quality data are not available near the time when land was removed from irrigation.

A distinct change in the stable-isotopic composition of water at a depth of $50 \mathrm{ft}$ was noted near the center of Lahontan Valley in previous work. This suggests that water in the intermediate aquifer near the center of Lahontan Valley was recharged prior to construction of Lahontan Reservoir. This change indicates it is unlikely that recent changes in irrigation practices will have an effect on water quality in the intermediate aquifer near the center of Lahontan Valley.

The monitoring-well network could be improved by the addition of new wells located near lands where reductions in irrigation will likely occur, yet distant from irrigation canals or ditches. Water-level measurements and water-quality samples could be obtained prior to removal of irrigation, with measurements and sampling continuing after removal of irrigation. Continued monitoring of wells near land removed from irrigation on the current network during periods of greater releases from Lahontan Reservoir would show if water levels continue to decline and the magnitude of total decline.

\section{References Cited}

Axelrod, D.I., 1956, Mid-Pliocene floras from west-central Nevada: University of California, Publications in Geological Sciences, v. 33, 322 p.

Berris, S.N., Crompton, E.J., Joyner, J.D., and Ryan, Roslyn, 2003, Water Resources Data Nevada, Water Year 2002: U.S. Geological Survey Water-Data Report NV-02-1, 600 p.

Bureau of Reclamation, 1987, Final environmental impact statement for the Newlands Project proposed operating criteria and procedures: Washington D.C., 332 p.

Bureau of Reclamation, 1988, Newlands Project Map No. 29-208-3: Sacramento, California, 1 sheet.
Davis, J.O., 1978, Quaternary tephrochronology of the Lake Lahontan area, Nevada and California: University of Nevada, Reno, Nevada Archeological Survey Research Paper 7, $137 \mathrm{p}$.

Fishman, M.J., ed. 1993, Methods of analysis by the U.S. Geological Survey National Water Quality LaboratoryDetermination of inorganic and organic constituents in water and fluvial sediments: U.S. Geological Survey Open-File Report 93-125.

Fishman, M.J., and Friedman, L.C., 1989, Methods for determination of inorganic substances in water and fluvial sediments: U.S. Geological Survey Techniques of WaterResources Investigations, book 5, chap. A1.

Glancy, P.A., 1986, Geohydrology of the basalt and unconsolidated sedimentary aquifers in the Fallon Area, Churchill County, Nevada: U.S. Geological Survey Water-Supply Paper 2263, 62 p.

Glancy, P.A., and Katzer, T.L., 1975 [1976], Water-resources appraisal of the Carson River Basin, western Nevada: Nevada Division of Water Resources, Reconnaissance Report 59, 126 p.

Hem, J.D., 1989, Study and interpretation of the chemical characteristics of natural water: U.S. Geological Survey Water-Supply Paper 2254, 263 p.

Herrera, N.B., Seiler, R.S., and Prudic, D.E., 2000, Conceptual evaluation of ground-water flow and simulated effects of changing irrigation practices on the shallow aquifer in the Fallon and Stillwater areas, Churchill County, Nevada: U.S. Geological Survey Water-Resources Investigations Report 99-4191, 70 p.

Hoffman, R.J., Hallock, R.J., Rowe, T.G., Lico, M.S., Burge, H.L., and Thompson, S.P., 1990, Reconnaissance investigation of water quality, bottom sediments, and biota associated with irrigation drainage in and near Stillwater Wildlife Management Area, Churchill County, Nevada, 1986-87: U.S. Geological Survey Water-Resources Investigations Report 89-4105, 150 p.

Lico, M.S., 1992, Detailed study of irrigation drainage in and near wildlife management areas, west-central Nevada, 1987-90. Part A - Water quality, sediment composition, and hydrochemical processes in Stillwater and Fernley Wildlife Management Areas: U.S. Geological Survey WaterResources Investigations Report 92-4024A, 65 p.

Lico, M.S., Welch, A.H., and Hughes, J.L., 1986, Hydrologic, lithologic, and chemical data for sediment in the shallow aquifer at two sites near Fallon, Churchill County, Nevada, 1984-85: U.S. Geological Survey Open-File Report 86-250, $43 \mathrm{p}$.

Lico, M.S., and Seiler, R.L, 1994, Ground-water quality and geochemistry, Carson Desert, Western Nevada: U.S. Geological Survey Open-File Report 94-31, 91 p. 


\section{Evaluation of USGS Monitoring-Well Network and Potential Effects of Changes in Water Use, Newlands Project}

Maurer, D.K., Johnson, A.K., and Welch A.H., 1996, Hydrogeology and potential effects of changes in water use, Carson Desert agricultural area, Churchill County, Nevada: U.S. Geological Survey Water-Supply Paper 2436, 106 p.

Maurer, D.K., and Welch, A.H., 2001, Hydrogeology and geochemistry of the Fallon Basalt and adjacent aquifers, and potential sources of basalt recharge, in Churchill County, Nevada: U.S. Geological Survey Water-Resources Investigations Report 01-4130, $72 \mathrm{p}$.

Morrison, R.B., 1964, Lake Lahontan-Geology of southern Carson Desert, Nevada: U.S. Geological Survey Professional Paper 401, $156 \mathrm{p}$.

Morrison, R.B., 1991, Quaternary stratigraphic, hydrologic, and climatic history of the Great Basin, with emphasis on Lakes Lahontan, Bonneville, and Tecopa, in Morrison, R.B., ed., The Geology of North America, Quaternary Nonglacial Geology-Conterminous U.S. Geological Society of America, v. K-2, p. 283-320.

National Oceanic and Atmospheric Administration, 2002, Monthly station normals of temperature, precipitation, and heating and cooling degree days 1971-2000: Climatology of the United States No. 81, 26 Nevada, National Climatic Data Center, Asheville, North Carolina, $26 \mathrm{p}$.

Rowe, T.G., Lico, M.S., Hallock, R.J., Maest, A.S., and Hoffman, R.J., 1991, Physical, chemical, and biological data for detailed study of irrigation drainage in and near Stillwater, Fernley, and Humboldt National Wildlife Management Areas and Carson Lake, west-central Nevada, 1987-89: U.S. Geological Survey Open-File Report 91-185, 199 p.

Rush, F.E., 1968, Index of hydrographic areas in Nevada: Nevada Division of Water Resources, Information Report 6, $38 \mathrm{p}$.
Seiler, R.L., and Allander, K.K., 1993, Water-level changes and directions of ground-water movement in the shallow aquifer, Fallon area, Churchill County, Nevada: U.S. Geological Survey Water-Resources Investigations Report 93-4118, $74 \mathrm{p}$.

Thomas, K.A., and Williams, R.P.,1997, Flood of January 1997 in the Carson River Basin, California and Nevada: U.S. Geological Survey Fact Sheet FS-183-97, 2 p.

Welch, A.H., Lawrence, S.J., Lico, M.S., Thomas, J.M., and Schaefer, D.H., 1997, Ground-water quality assessment of the Carson River Basin, Nevada and California-results of investigations, 1987-91: U.S. Geological Survey WaterSupply Paper 2356-A, 93 p.

Whitney, Rita, 1994, Data on ground-water quality in the Carson River basin, western Nevada and eastern California, 1987-90: U.S. Geological Survey Open-File Report 94-39, $139 \mathrm{p}$.

U.S. Census Bureau, 2004a, Population, housing units, area, and density: 2000 Nevada - Place, accessed July 7, 2004 at URL <http://factfinder.census.gov/servlet/GCTTable?_bm= y\&-geo_id=04000US32\&-_box_head_nbr=GCT-PH1\&ds_name $=$ DEC_2000_SF1_U\&-redoLog=false \&mt_name=DEC_2000_SF1_U_GCTPH1_ST2\&-format= ST-7> .

U.S. Census Bureau, 2004b, Population, housing units, area, and density: 2000 Nevada - County, accessed July 7, 2004 at URL <http://factfinder.census.gov/servlet/GCTTable?_bm= y\&-geo_id=04000US32\&-_box_head_nbr=GCT-PH1\&ds_name=DEC_2000_SF1_U\&-redoLog=false \&-format= ST-2\&-mt_name=DEC_2000_SF1_U_GCTPH1_ST7 >. 


\section{APPENDIXES}


Appendix A.--Monitoring well measurement frequency 1998-2003, site identifier, location, and well construction data.

[Symbols: A, annual; Q, quarterly; M, monthly; I, intermittent; S, sampled; -- indicates not known. Datum for location NAD 27.]

Site no. (Seiler Site no. and Allander, (figure 3) 1993)/measurement frequency

$\begin{array}{llll} & \text { Local site } & \text { Latitude } & \text { Longitude } \\ \text { Site identifier } & & \text { (decimal } & \text { (decimal } \\ & \text { identification } & & \\ \text { degrees) } & \text { degrees) }\end{array}$

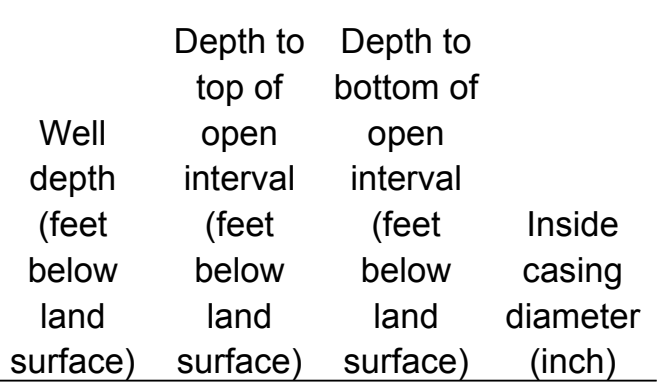

\begin{tabular}{|c|c|c|c|c|c|c|c|}
\hline & & & & surface) & surface) & surface) & (inch) \\
\hline 1 & $45 / Q$ & 393108118590801101 N19 E27 08CCCB1 & $39.5188036-118.9865486$ & 69 & -- & -- & 8 \\
\hline 2 & $46 / Q$ & 393106118580301101 N19 E27 09CCCC1 & $39.5182778-118.9685278$ & 21 & 16 & 21 & 2 \\
\hline 3 & $53 / Q$ & 392948118561101101 N19 E27 22DBAB1 & $39.4964167-118.9374444$ & 13 & 8 & 13 & 2 \\
\hline 4 & $51 / Q$ & 393043118555101101 N19 E27 15ADDA1 & $39.5118600-118.9318244$ & 21 & -- & -- & 2 \\
\hline 5 & $47 / Q$ & 393120118545501101 N19 E27 11DCAC1 & $39.5199156-118.9190464$ & 24 & -- & -- & 2 \\
\hline 6 & 50/M & 393023118544103101 N19 E27 13ССВB3 & $39.5063047-118.9123794$ & 28 & 23 & 28 & 2 \\
\hline 7 & $48 / \mathrm{M}$ & 393023118544101101 N19 E27 13CCB 1 & $39.5063047-118.9123794$ & 143 & 141 & 143 & 1.5 \\
\hline 8 & $56 / Q$ & 393142118533201101 N19 E28 07BCBB1 & $39.5282489-118.8932122$ & 26 & -- & -- & 2 \\
\hline 9 & 60/M & 392926118533001101 N19 E28 19CCCB1 & $39.4904717-118.8926564$ & 18 & 16 & 18 & 2 \\
\hline 10 & $55 / Q$ & 392828118534901101 N19 E27 36DDCD1 & $39.4743608-118.8979339$ & 26 & 23 & 26 & 2 \\
\hline 11 & 59/M & 393038118512201101 N19 E28 17DAAC1 & $39.5104719-118.8570997$ & 14 & 11 & 13 & 2 \\
\hline 12 & none/M,S & 393006118515101101 N19 E28 20ABDA1 & $39.5015831-118.8651556$ & 24 & 19 & 24 & 2 \\
\hline 13 & none/M,S & 393004118514201101 N19 E28 20ABC 1 & $39.5010275-118.8626556$ & 29 & 19 & 29 & 2 \\
\hline 14 & $63 / M, S$ & 392829118520001101 N19 E28 32BAAB1 & $39.4746389-118.8676553$ & 13 & 10 & 12 & 2 \\
\hline 15 & $17 / Q$ & 392609118513401101 N18 E28 08DACB1 & $39.4357508-118.8604319$ & 29 & 16 & 28 & 10 \\
\hline 16 & $65 / Q$ & 392817118495501101 N19 E28 34BCAA1 & $39.4701950-118.8323761$ & 13 & 8 & 13 & 2 \\
\hline 17 & $16 / Q$ & 392735118484501101 N18 E28 02BABB1 & $39.4598889-118.8134167$ & 27 & 22 & 27 & 2 \\
\hline 18 & $62 / \mathrm{M}$ & 392925118482001101 N19 E28 23DCCA1 & $39.4903422-118.8073506$ & 30 & -- & -- & 8 \\
\hline 19 & $58 / \mathrm{A}$ & 393155118483002101 N19 E28 11ABB 2 & $39.5318611-118.8093206$ & 35 & 31 & 32 & 1.5 \\
\hline 20 & $57 / A$ & 393155118483001101 N19 E28 11ABB 1 & $39.5318611-118.8093206$ & 97 & 96 & 97 & 1.5 \\
\hline 21 & $106 / \mathrm{A}$ & 393309118515901101 N20 E28 32CAD 1 & $39.5524156-118.8673781$ & 128 & -- & -- & 1.5 \\
\hline 22 & $104 / \mathrm{A}$ & 393335118512701101 N20 E28 32AAD 1 & $39.5596378-118.8584889$ & 32 & -- & -- & 1.5 \\
\hline
\end{tabular}




\begin{tabular}{|c|c|c|c|c|c|c|c|c|}
\hline 23 & 105/A & 393335118512702101 & N20 E28 32AADA2 & $39.5596378-118.8584889$ & 22 & 20 & 22 & 1.5 \\
\hline 24 & $99 / \mathrm{A}$ & 393442118501802101 & N20 E28 21DDDC2 & $39.5782489-118.8393217$ & 9 & 7 & 9 & 2 \\
\hline 25 & $98 / \mathrm{A}$ & 393442118501801101 & N20 E28 21DDDC1 & $39.5782489-118.8393217$ & 67 & 66 & 67 & 1.5 \\
\hline 26 & $101 / A$ & 393515118495602101 & N20 E28 22BCA 2 & $39.5874156-118.8332106$ & 35 & 32 & 34 & 1.5 \\
\hline 27 & 100/A & 393515118495601101 & N20 E28 22BCA 1 & $39.5874156-118.8332106$ & 87 & 84 & 86 & 1.5 \\
\hline 28 & none/A & 393854118463801101 & N21 E28 25ADD 1 & $39.6482486-118.7782089$ & 150 & -- & -- & 1.5 \\
\hline 29 & 125/A & 394046118472603101 & N21 E28 24BBA 3 & $39.6793589-118.7915428$ & 13 & 11 & 13 & 2 \\
\hline 30 & $124 / A$ & 394046118472601101 & N21 E28 24BBA 1 & $39.6793589-118.7915428$ & 109 & 106 & 109 & 1.5 \\
\hline 31 & $110 / \mathrm{M}, \mathrm{S}$ & 393458118431101101 & N20 E29 22CBAC1 & $39.5849167-118.7237619$ & 12 & 9 & 12 & 2 \\
\hline 32 & 66/Q & 393252118415901101 & N19 E29 02BABB1 & $39.5476953-118.7007053$ & 21 & 16 & 21 & 2 \\
\hline 33 & $117 / Q$ & 393651118325701101 & N20 E31 07BDCA1 & $39.6140842-118.5501439$ & 20 & 15 & 20 & 2 \\
\hline 34 & $123 / \mathrm{A}$ & 393341118241401101 & N20 E32 33BBBD1 & $39.5613075-118.4048608$ & -- & -- & -- & 4 \\
\hline 35 & $95 / \mathrm{A}$ & 393153118275301101 & N19 E31 11AACA1 & $39.5313081-118.4656958$ & 81 & -- & -- & 6 \\
\hline 36 & $122 / Q$ & 393311118304703101 & N20 E31 33CACB3 & $39.5529742-118.5140308$ & 28 & 23 & 28 & 2 \\
\hline 37 & 96/Q & 393106118305301101 & N19 E31 16BBDB1 & $39.5182528-118.5156972$ & 25 & 22 & 25 & 2 \\
\hline 38 & $97 / Q$ & 393056118304901101 & N19 E31 16BCAA1 & $39.5154750-118.5145861$ & 30 & 26 & 30 & 2 \\
\hline 39 & $82 / \mathrm{M}, \mathrm{S}$ & 393052118333501101 & N19 E30 13ACAA1 & $39.5141389-118.5610000$ & 12 & 10 & 12 & 2 \\
\hline 40 & $112 / \mathrm{A}$ & 393309118344701101 & N20 E30 35DBDD1 & $39.5524183-118.5807003$ & 27 & 22 & 27 & 2 \\
\hline 41 & $78 / \mathrm{A}$ & 393248118374901101 & N19 E30 04BBBC1 & $39.5465847-118.6312578$ & 15 & 4 & 15 & 3 \\
\hline 42 & $79 / A$ & 393200118382601101 & N19 E30 08BAAA1 & $39.5332514-118.6415361$ & 9 & -- & -- & 2 \\
\hline 43 & $81 / Q$ & 393110118361001101 & N19 E30 10CDDD1 & $39.5193631-118.6037567$ & 8 & -- & -- & 2 \\
\hline 44 & $80 / Q$ & 393114118361001101 & N19 E30 10CDDA1 & $39.5204742-118.6037567$ & 15 & 11 & 15 & 1 \\
\hline 45 & $86 / \mathrm{M}$ & 392938118344301101 & N19 E30 23DBDD2 & $39.4938081-118.5795886$ & 11 & -- & -- & 12 \\
\hline 46 & 93/M & 392828118361202101 & N19 E30 34BAA 2 & $39.4743636-118.6043117$ & 13 & -- & -- & 2 \\
\hline 47 & 92/M & 392828118361201101 & N19 E30 34BAA 1 & $39.4743636-118.6043117$ & 25 & -- & -- & 2 \\
\hline 48 & none/A & 392758118365101101 & N19 E30 33ADD 1 & $39.4660303-118.6151453$ & 11 & -- & -- & 2 \\
\hline 49 & 90/Q & 392828118370702101 & N19 E30 33ABAB2 & $39.4743633-118.6195900$ & 18 & -- & -- & 2 \\
\hline 50 & $71 / \mathrm{M}, \mathrm{S}$ & 393003118402001101 & N19 E29 24ABDD1 & $39.5007517-118.6732039$ & 12 & 11 & 12 & 2 \\
\hline 51 & $67 / Q$ & 393049118413501101 & N19 E29 14ACB 2 & $39.5124181-118.6945939$ & 12 & 10 & 12 & 2 \\
\hline 52 & $70 / Q$ & 392924118420901101 & N19 E29 23CCDC1 & $39.4899183-118.7034828$ & 19 & -- & -- & 1.75 \\
\hline 53 & $77 / Q$ & 392759118411601101 & N19 E29 35DAA 1 & $39.4663075-118.6887594$ & 10 & 8 & 10 & 2 \\
\hline 54 & $75 / Q$ & 392825118435501101 & N19 E29 33ABAC1 & $39.4735292-118.7329281$ & 28 & 24 & 28 & 8.63 \\
\hline 55 & $74 / Q$ & 392816118453901101 & N19 E29 32BCBB1 & $39.4710292-118.7618181$ & 21 & -- & -- & -- \\
\hline
\end{tabular}


Site no. (Seiler Site no. and Allander, (figure 3) 1993)/measurement frequency
Latitude Longitude

(decimal (decimal degrees) degrees)
Depth to Depth to top of bottom of

Site identifier ${ }^{1}$

Local site

identification $^{2}$ open open interval interval

(feet (feet

depth

(feet

below

land

below below

Inside land land diameter surface) surface) surface) (inch)

\begin{tabular}{|c|c|c|c|c|c|c|c|c|}
\hline & & & & & & & & \\
\hline 56 & $19 / \mathrm{M}$ & 392642118470901101 & N18 E28 12ABAC1 & $39.4449181-118.7868186$ & 15 & 12 & 15 & 2 \\
\hline 57 & $28 / Q$ & 392540118454501101 & N18 E29 18AADD1 & $39.4274722-118.7635556$ & 23 & 18 & 23 & 2 \\
\hline 58 & 29/M & 392439118443401101 & N18 E29 21BCCB1 & $39.4107519-118.7437608$ & 30 & -- & -- & 5 \\
\hline 59 & $40 / \mathrm{A}$ & 392554118373001101 & N18 E30 09CDCC1 & $39.4315858-118.6259786$ & 111 & -- & -- & 1 \\
\hline 60 & $42 / \mathrm{A}$ & 392407118392301101 & N18 E30 30ABBA1 & $39.4018636-118.6573681$ & 24 & 19 & 24 & 2 \\
\hline 61 & $43 / \mathrm{A}$ & 392316118390001101 & N18 E30 30DDDC1 & $39.3876972-118.6509789$ & 30 & 25 & 30 & 2 \\
\hline 62 & $37 / M$ & 392309118414601101 & N18 E29 35ABCB1 & $39.3857525-118.6970917$ & 32 & 25 & 30 & 6 \\
\hline 63 & $38 / \mathrm{M}$ & 392305118414601101 & N18 E29 35ABCC1 & $39.3846414-118.6970917$ & 128 & 124 & 128 & 6 \\
\hline 64 & $34 / M, S$ & 392327118425401101 & N18 E29 27CDAD1 & $39.3907522-118.7159817$ & 13 & 11 & 13 & 2 \\
\hline 65 & $35 / 1$ & 392348118464401101 & N18 E29 30BCBD1 & $39.3965853-118.7798731$ & 29 & 27 & 29 & 2 \\
\hline 66 & $20 / 1$ & 392359118492501101 & N18 E28 34ACAA1 & $39.3838072-118.8243186$ & 10 & 7 & 10 & 2 \\
\hline 67 & $6 / Q$ & 392208118452701101 & N17 E29 05BCAA1 & $39.3685556-118.7585556$ & 28 & 23 & 28 & 2 \\
\hline 68 & $10 / Q$ & 392132118411004101 & N17 E29 12BBBB4 & $39.3588083-118.6870908$ & 15 & 10 & 15 & 2 \\
\hline 69 & $7 / Q$ & 392132118411001101 & N17 E29 12BBBB1 & $39.3588083-118.6870908$ & 50 & 45 & 50 & 2 \\
\hline 70 & $5 / \mathrm{M}$ & 392008118465501101 & N17 E28 13DAA 1 & $39.3354747-118.7829275$ & 17 & 15 & 17 & 1.5 \\
\hline 71 & $11 / \mathrm{A}$ & 391853118455801101 & N17 E29 19DDCC1 & $39.3146417-118.7670933$ & 23 & 18 & 23 & 2 \\
\hline 72 & $1 / \mathrm{Q}$ & 391705118465402101 & N16 E28 01AAAA2 & $39.2846419-118.7826486$ & 27 & 22 & 27 & 2 \\
\hline 73 & $15 / A$ & 391857118383801101 & N17 E30 20CDCC1 & $39.3157533-118.6448661$ & 24 & 19 & 24 & 2 \\
\hline 74 & $2 / \mathrm{A}$ & 391706118403801101 & N16 E29 01ABBB1 & $39.2849200-118.6782003$ & 30 & 22 & 32 & 2 \\
\hline 75 & $4 / \mathrm{A}$ & 391532118371601101 & N16 E30 09CDAA1 & $39.2588092-118.6220867$ & 27 & -- & -- & 6 \\
\hline
\end{tabular}

${ }^{1}$ The site identifier is based on the grid system of latitude and longitude. The number consists of 15 digits. The first six denote the degrees, minutes, and seconds of latitude; the next seven digits denote the degrees, minutes, and second of longitude; and the last two digits (assigned sequentially) identify the sites within a 1-second grid. For example, site 39264211847090 is at $39^{\circ} 26^{\prime} 42^{\prime \prime} \mathrm{N}$ latitude and $188^{\circ} 47^{\prime} 09^{\prime \prime} \mathrm{W}$ longitude, and is the first site recorded in that 1-second grid. The assigned number is retained as a permanent identifier even if a more precise latitude and longitude are determined.

${ }^{2}$ The local site identification is used in Nevada to identify a site by hydrographic area (Rush, 1968) and by the official rectangular subdivision of the public lands referenced to the Mount Diablo baseline and meridian. Each site designation consists of four units: The first unit is the hydrographic area number. The second unit is the township preceded by an $\mathrm{N}$ or $\mathrm{S}$ to indicate location north or south of the baseline. The third unit is the range, preceded by an $\mathrm{E}$ to indicate location east of the meridian. The fourth unit consists of the section number and letters designating the quarter section, quarter-quarter section, and so on (A, B, C, and D indicate the northeast, northwest, southwest, and southeast quarters, respectively), followed by a number indicating the sequence in which the site was recorded. For example, site 101 N18 E28 12 ABAC1 is in the Carson Desert (Hydrographic Area 101). It is the first site recorded in the northeast quarter of the northwest quarter of the northeast quarter of the southeast quarter of section 12, Township 18 north, Range 28 east, Mount Diablo baseline and meridian. 
Appendix B. Truckee-Carson Irrigation District (TCID) serial numbers of parcels near monitoring wells and summary of parcel size, average distance of parcel from well, gradient direction, irrigation history for water years 1992 through 2003, and irrigation prior to 1992 for parcels not irrigated 1992-2003. Parcels grouped and summarized by gradient direction. Irrigation history and acreages are approximate.

[The average distance of parcels from USGS monitoring wells was determined by multiplying the acreage of individual fields by the minimum distance of the field from the well, totaling the values, and dividing the total by the total acreage of the parcel. The resulting average distances represent the approximate center point of the parcels. Shaded cells indicate average distance of all parcels in a similar direction from well.

Symbols: nd, indicates no data; $\mathrm{U}$, indicates upgradient direction; $\mathrm{L}$, indicates lateral direction; D, indicates downgradient direction; I, indicates irrigated; NI, indicates not irrigated.

Acreage of zero indicates parcel still irrigated as of 2003. Average distance of zero indicates acreage surrounds well. Average distances for totals rounded to nearest 10 feet.]

\begin{tabular}{|c|c|c|c|c|c|c|c|c|c|c|c|c|c|c|c|c|c|c|}
\hline $\begin{array}{c}\text { Site } \\
\text { number } \\
\text { (figure 3) }\end{array}$ & $\begin{array}{c}\text { TCID } \\
\text { serial } \\
\text { number }\end{array}$ & $\begin{array}{c}\text { Parcel } \\
\text { size } \\
\text { (acres) }^{a}\end{array}$ & $\begin{array}{l}\text { Average } \\
\text { distance } \\
\text { of parcel } \\
\text { from well } \\
\text { (feet) }\end{array}$ & $\begin{array}{c}\text { Acres } \\
\text { times } \\
\text { distance }^{b}\end{array}$ & $\begin{array}{l}\text { Gradient } \\
\text { direction }\end{array}$ & 1992 & 1993 & 1994 & 1995 & 1996 & 1997 & 1998 & 1999 & 2000 & 2001 & 2002 & 2003 & $\begin{array}{c}\text { Irrigation } \\
\text { prior to } \\
1992 \\
\end{array}$ \\
\hline \multirow[t]{9}{*}{2} & 5351 & 48 & 7,600 & 363,280 & U & 1 & 1 & 1 & 1 & 1 & I & $\mathrm{NI}$ & $\mathrm{NI}$ & $\mathrm{NI}$ & $\mathrm{NI}$ & $\mathrm{NI}$ & $\mathrm{NI}$ & \\
\hline & 371 & 33 & 8,300 & 277,220 & $U$ & I & I & 1 & I & 1 & I & $\mathrm{NI}$ & $\mathrm{NI}$ & $\mathrm{NI}$ & $\mathrm{NI}$ & $\mathrm{NI}$ & $\mathrm{NI}$ & \\
\hline & 374 & 75 & 5,600 & 417,760 & $U$ & I & I & 1 & I & 1 & I & $\mathrm{NI}$ & $\mathrm{NI}$ & $\mathrm{NI}$ & $\mathrm{NI}$ & $\mathrm{NI}$ & $\mathrm{NI}$ & \\
\hline & 376 & 69 & 3,300 & 226,050 & $U$ & I & I & 1 & I & 1 & I & $\mathrm{NI}$ & $\mathrm{NI}$ & $\mathrm{NI}$ & $\mathrm{NI}$ & $\mathrm{NI}$ & $\mathrm{NI}$ & \\
\hline & 5350 & 70 & 6,000 & 418,800 & $U$ & 1 & 1 & 1 & I & 1 & 1 & $\mathrm{NI}$ & $\mathrm{NI}$ & $\mathrm{NI}$ & $\mathrm{NI}$ & $\mathrm{NI}$ & $\mathrm{NI}$ & \\
\hline & 378 & 31 & 4,300 & 133,730 & $U$ & I & I & 1 & 1 & 1 & I & $\mathrm{NI}$ & $\mathrm{NI}$ & $\mathrm{NI}$ & $\mathrm{NI}$ & $\mathrm{NI}$ & $\mathrm{NI}$ & \\
\hline & 409 & 68 & 3,200 & 216,000 & $U$ & I & 1 & 1 & I & 1 & I & $\mathrm{NI}$ & $\mathrm{NI}$ & $\mathrm{NI}$ & $\mathrm{NI}$ & $\mathrm{NI}$ & $\mathrm{NI}$ & \\
\hline & 407 & 31 & 1,800 & 55,080 & $U$ & I & 1 & 1 & I & 1 & I & $\mathrm{NI}$ & $\mathrm{NI}$ & $\mathrm{NI}$ & $\mathrm{NI}$ & $\mathrm{NI}$ & $\mathrm{NI}$ & \\
\hline & 411 & 14 & 1,300 & 18,720 & $U$ & I & I & 1 & I & 1 & I & $\mathrm{NI}$ & $\mathrm{NI}$ & $\mathrm{NI}$ & $\mathrm{NI}$ & $\mathrm{NI}$ & $\mathrm{NI}$ & \\
\hline \multicolumn{2}{|c|}{ Total upgradient } & 438 & 4,860 & $2,126,640$ & c & & & & & & & & & & & & & \\
\hline 14 & $567-2$ & 22 & 1,200 & & $\mathrm{~L}$ & 1 & I & 1 & I & 1 & $\mathrm{NI}$ & $\mathrm{NI}$ & $\mathrm{NI}$ & $\mathrm{NI}$ & $\mathrm{NI}$ & $\mathrm{NI}$ & $\mathrm{NI}$ & \\
\hline \multirow[t]{3}{*}{16} & $592-4 \& 7$ & 24 & 2,990 & 70,564 & $U$ & $\mathrm{NI}$ & $\mathrm{NI}$ & $\mathrm{NI}$ & $\mathrm{NI}$ & $\mathrm{NI}$ & $\mathrm{NI}$ & $\mathrm{NI}$ & $\mathrm{NI}$ & $\mathrm{NI}$ & $\mathrm{NI}$ & $\mathrm{NI}$ & $\mathrm{NI}$ & I- $90 \& 91$ \\
\hline & 554 & 45 & 2,550 & 115,005 & $U$ & I & 1 & 1 & 1 & $\mathrm{NI}$ & $\mathrm{NI}$ & $\mathrm{NI}$ & $\mathrm{NI}$ & $\mathrm{NI}$ & $\mathrm{NI}$ & $\mathrm{NI}$ & $\mathrm{NI}$ & \\
\hline & $565-44$ & 26 & 5,650 & 145,770 & $U$ & $\mathrm{NI}$ & I & $\mathrm{NI}$ & $\mathrm{NI}$ & $\mathrm{NI}$ & $\mathrm{NI}$ & $\mathrm{NI}$ & $\mathrm{NI}$ & $\mathrm{NI}$ & $\mathrm{NI}$ & $\mathrm{NI}$ & $\mathrm{NI}$ & I-91 \& prior \\
\hline \multicolumn{2}{|c|}{ Total upgradient } & 95 & 3,510 & 331,339 & C & & & & & & & & & & & & & \\
\hline \multirow[t]{2}{*}{21} & $854-2 \& 3$ & 35 & 5,900 & 205,320 & $U$ & $\mathrm{NI}$ & $\mathrm{NI}$ & $\mathrm{NI}$ & $\mathrm{NI}$ & $\mathrm{NI}$ & $\mathrm{NI}$ & $\mathrm{NI}$ & $\mathrm{NI}$ & $\mathrm{NI}$ & $\mathrm{NI}$ & $\mathrm{NI}$ & $\mathrm{NI}$ & NI from 87 \\
\hline & $455-3$ to- 6 & 63 & 4,040 & 254,520 & $U$ & $\mathrm{NI}$ & $\mathrm{NI}$ & $\mathrm{NI}$ & $\mathrm{NI}$ & $\mathrm{NI}$ & $\mathrm{NI}$ & $\mathrm{NI}$ & $\mathrm{NI}$ & $\mathrm{NI}$ & $\mathrm{NI}$ & $\mathrm{NI}$ & $\mathrm{NI}$ & $\mathrm{NI}$ from 87 \\
\hline \multicolumn{2}{|c|}{ Total upgradient } & 98 & 4,700 & 459,840 & c & & & & & & & & & & & & & \\
\hline \multirow[t]{2}{*}{31} & $865 w$ & 119 & 350 & 41,475 & L & I & $\mathrm{NI}$ & 1 & $\mathrm{NI}$ & $\mathrm{NI}$ & $\mathrm{NI}$ & $\mathrm{NI}$ & $\mathrm{NI}$ & $\mathrm{NI}$ & $\mathrm{NI}$ & $\mathrm{NI}$ & $\mathrm{NI}$ & \\
\hline & $865 \mathrm{e}$ & 96 & 3,330 & 320,679 & L & $\mathrm{NI}$ & $\mathrm{NI}$ & $\mathrm{NI}$ & $\mathrm{NI}$ & $\mathrm{NI}$ & $\mathrm{NI}$ & $\mathrm{NI}$ & $\mathrm{NI}$ & $\mathrm{NI}$ & $\mathrm{NI}$ & $\mathrm{NI}$ & $\mathrm{NI}$ & \\
\hline \multicolumn{2}{|c|}{ Total lateral } & 215 & 1,690 & 362,154 & c & & & & & & & & & & & & & \\
\hline
\end{tabular}




\begin{tabular}{|c|c|c|c|c|c|c|c|c|c|c|c|c|c|c|c|c|c|c|}
\hline $\begin{array}{c}\text { Site } \\
\text { number } \\
\text { (figure 3) }\end{array}$ & $\begin{array}{c}\text { TCID } \\
\text { serial } \\
\text { number }\end{array}$ & $\begin{array}{c}\text { Parcel } \\
\text { size } \\
\text { (acres) }^{a}\end{array}$ & $\begin{array}{l}\text { Average } \\
\text { distance } \\
\text { of parcel } \\
\text { from well } \\
\text { (feet) }\end{array}$ & $\begin{array}{c}\text { Acres } \\
\text { times } \\
\text { distance }^{b}\end{array}$ & $\begin{array}{l}\text { Gradient } \\
\text { direction }\end{array}$ & 1992 & 1993 & 1994 & 1995 & 1996 & 1997 & 1998 & 1999 & 2000 & 2001 & 2002 & 2003 & $\begin{array}{c}\text { Irrigation } \\
\text { prior to } \\
1992\end{array}$ \\
\hline \multirow[t]{2}{*}{36} & $819-2$ & 208 & 3,960 & 825,264 & $U$ & 1 & 1 & I & 1 & I & 1 & 1 & $\mathrm{NI}$ & I & $\mathrm{NI}$ & $\mathrm{NI}$ & $\mathrm{NI}$ & \\
\hline & 2169 & 27 & 500 & 13,500 & $U$ & $\mathrm{NI}$ & 1 & 1 & $\mathrm{NI}$ & 1 & 1 & 1 & $\mathrm{NI}$ & $\mathrm{NI}$ & $\mathrm{NI}$ & $\mathrm{NI}$ & $\mathrm{NI}$ & \\
\hline \multicolumn{2}{|c|}{ Total upgradient } & 235 & 3,560 & 838,764 & C & & & & & & & & & & & & & \\
\hline & 819-1-B & 456 & 5,350 & $2,436,925$ & $\mathrm{~L}$ & 1 & 1 & I & 1 & 1 & 1 & 1 & I & 1 & $\mathrm{NI}$ & $\mathrm{NI}$ & $\mathrm{NI}$ & \\
\hline \multicolumn{2}{|c|}{ Site total } & 691 & & & & & & & & & & & & & & & & \\
\hline \multirow[t]{2}{*}{$37 \& 38$} & 825 & 157 & 5,110 & 804,314 & $U$ & I & 1 & I & I & I & 1 & I & $\mathrm{NI}$ & $\mathrm{NI}$ & $\mathrm{NI}$ & $\mathrm{NI}$ & $\mathrm{NI}$ & \\
\hline & 827 & 29 & 8,000 & 234,400 & $U$ & $\mathrm{NI}$ & 1 & I & 1 & I & 1 & 1 & $\mathrm{NI}$ & $\mathrm{NI}$ & $\mathrm{NI}$ & $\mathrm{NI}$ & $\mathrm{NI}$ & \\
\hline \multicolumn{2}{|c|}{ Total upgradient } & 187 & 5,560 & $1,038,714$ & c & & & & & & & & & & & & & \\
\hline & 2169-B & 12 & 6,200 & 76,880 & $\mathrm{~L}$ & $\mathrm{NI}$ & 1 & 1 & $\mathrm{NI}$ & $\mathrm{NI}$ & $\mathrm{NI}$ & $\mathrm{NI}$ & $\mathrm{NI}$ & $\mathrm{NI}$ & $\mathrm{NI}$ & $\mathrm{NI}$ & $\mathrm{NI}$ & \\
\hline & 821 & 540 & 4,860 & $2,621,970$ & $\mathrm{~L}$ & 1 & I & I & I & I & 1 & I & 1 & $\mathrm{NI}$ & $\mathrm{NI}$ & $\mathrm{NI}$ & $\mathrm{NI}$ & \\
\hline \multicolumn{2}{|c|}{ Total lateral } & 552 & 4,890 & $2,698,850$ & c & & & & & & & & & & & & & \\
\hline & $821-8$ & 148 & 8,230 & $1,213,925$ & $\mathrm{D}$ & 1 & $\mathrm{NI}$ & $\mathrm{NI}$ & 1 & 1 & $\mathrm{NI}$ & $\mathrm{NI}$ & $\mathrm{NI}$ & $\mathrm{NI}$ & $\mathrm{NI}$ & $\mathrm{NI}$ & $\mathrm{NI}$ & \\
\hline & 2169-A & 33 & 2,820 & 93,342 & $\mathrm{D}$ & $\mathrm{NI}$ & 1 & 1 & 1 & $\mathrm{NI}$ & $\mathrm{NI}$ & 1 & 1 & 1 & $\mathrm{NI}$ & $\mathrm{NI}$ & $\mathrm{NI}$ & \\
\hline & $821-6$ & 80 & 5,810 & 466,543 & $\mathrm{D}$ & 1 & 1 & I & I & 1 & $\mathrm{NI}$ & $\mathrm{NI}$ & I & $\mathrm{NI}$ & $\mathrm{NI}$ & 1 & $\mathrm{NI}$ & \\
\hline \multicolumn{2}{|c|}{ Total downgradient } & 261 & 6,800 & $1,773,810$ & c & & & & & & & & & & & & & \\
\hline \multicolumn{2}{|c|}{ Site total } & 1,000 & & & & & & & & & & & & & & & & \\
\hline \multirow[t]{3}{*}{39} & $821-5$ & 154 & 4,260 & 653,910 & $U$ & $\mathrm{NI}$ & 1 & $\mathrm{NI}$ & I & $\mathrm{NI}$ & $\mathrm{NI}$ & $\mathrm{NI}$ & $\mathrm{NI}$ & $\mathrm{NI}$ & $\mathrm{NI}$ & $\mathrm{NI}$ & $\mathrm{NI}$ & \\
\hline & 828 & 42 & 1,370 & 57,814 & $U$ & 1 & I & $\mathrm{NI}$ & I & I & I & I & I & I & 1 & I & $\mathrm{NI}$ & \\
\hline & 770 & 73 & 2,120 & 155,396 & $U$ & $\mathrm{NI}$ & I & I & I & $\mathrm{NI}$ & $\mathrm{NI}$ & $\mathrm{NI}$ & $\mathrm{NI}$ & $\mathrm{NI}$ & $\mathrm{NI}$ & $\mathrm{NI}$ & $\mathrm{NI}$ & \\
\hline \multicolumn{2}{|c|}{ Total upgradient } & 269 & 3,220 & 867,120 & c & & & & & & & & & & & & & \\
\hline & 830 & 318 & 2,540 & & $\mathrm{~L}$ & $\mathrm{NI}$ & $\mathrm{NI}$ & $\mathrm{NI}$ & $\mathrm{NI}$ & $\mathrm{NI}$ & $\mathrm{NI}$ & $\mathrm{NI}$ & $\mathrm{NI}$ & $\mathrm{NI}$ & $\mathrm{NI}$ & $\mathrm{NI}$ & $\mathrm{NI}$ & I- 90 \\
\hline & $773-2$ & 34 & 2,560 & & $\mathrm{D}$ & 1 & 1 & 1 & $\mathrm{NI}$ & $\mathrm{NI}$ & $\mathrm{NI}$ & $\mathrm{NI}$ & $\mathrm{NI}$ & $\mathrm{NI}$ & $\mathrm{NI}$ & $\mathrm{NI}$ & $\mathrm{NI}$ & \\
\hline \multicolumn{2}{|c|}{ Site total } & 621 & & & & & & & & & & & & & & & & \\
\hline \multirow[t]{8}{*}{40} & 746 & 146 & 5,790 & 847,077 & $U$ & 1 & 1 & $\mathrm{NI}$ & $\mathrm{NI}$ & $\mathrm{NI}$ & $\mathrm{NI}$ & $\mathrm{NI}$ & $\mathrm{NI}$ & $\mathrm{NI}$ & $\mathrm{NI}$ & $\mathrm{NI}$ & $\mathrm{NI}$ & \\
\hline & 747 & 73 & 5,980 & 438,334 & $U$ & $\mathrm{NI}$ & $\mathrm{NI}$ & $\mathrm{NI}$ & $\mathrm{NI}$ & $\mathrm{NI}$ & $\mathrm{NI}$ & $\mathrm{NI}$ & I & $\mathrm{NI}$ & $\mathrm{NI}$ & $\mathrm{NI}$ & $\mathrm{NI}$ & \\
\hline & 758 & 73 & 7,000 & 508,200 & $U$ & $\mathrm{NI}$ & 1 & I & $\mathrm{NI}$ & $\mathrm{NI}$ & $\mathrm{NI}$ & $\mathrm{NI}$ & $\mathrm{NI}$ & $\mathrm{NI}$ & $\mathrm{NI}$ & $\mathrm{NI}$ & $\mathrm{NI}$ & \\
\hline & 744 & 207 & 6,170 & $1,274,722$ & $U$ & I & 1 & 1 & I & $\mathrm{NI}$ & 1 & 1 & 1 & 1 & $\mathrm{NI}$ & $\mathrm{NI}$ & $\mathrm{NI}$ & \\
\hline & 750 & 107 & 4,680 & 501,696 & $U$ & I & 1 & 1 & I & I & $\mathrm{NI}$ & $\mathrm{NI}$ & $\mathrm{NI}$ & $\mathrm{NI}$ & $\mathrm{NI}$ & $\mathrm{NI}$ & $\mathrm{NI}$ & \\
\hline & 752 & 7 & 1,400 & 9,800 & $U$ & 1 & 1 & 1 & 1 & 1 & I & 1 & 1 & $\mathrm{NI}$ & 1 & I & $\mathrm{NI}$ & \\
\hline & $752-1$ & 144 & 3,470 & 499,333 & $U$ & I & I & 1 & $\mathrm{NI}$ & $\mathrm{NI}$ & $\mathrm{NI}$ & $\mathrm{NI}$ & $\mathrm{NI}$ & $\mathrm{NI}$ & $\mathrm{NI}$ & $\mathrm{NI}$ & $\mathrm{NI}$ & \\
\hline & 759 & 69 & 7,680 & 532,224 & $U$ & 1 & 1 & I & 1 & I & I & 1 & I & 1 & I & I & $\mathrm{NI}$ & \\
\hline
\end{tabular}




\section{Average}

distance

\begin{tabular}{|c|c|c|c|c|c|c|c|c|c|c|c|c|c|c|c|c|c|c|}
\hline $\begin{array}{c}\text { Site } \\
\text { number } \\
\text { (figure 3) }\end{array}$ & $\begin{array}{c}\text { TCID } \\
\text { serial } \\
\text { number }\end{array}$ & $\begin{array}{l}\text { Parcel } \\
\text { size } \\
\text { (acres) }^{a}\end{array}$ & $\begin{array}{c}\text { of parcel } \\
\text { from well } \\
\text { (feet) }\end{array}$ & $\begin{array}{c}\text { Acres } \\
\text { times } \\
\text { distance }^{b}\end{array}$ & $\begin{array}{l}\text { Gradient } \\
\text { direction }\end{array}$ & 1992 & 1993 & 1994 & 1995 & 1996 & 1997 & 1998 & 1999 & 2000 & 2001 & 2002 & 2003 & $\begin{array}{c}\text { Irrigation } \\
\text { prior to } \\
1992 \\
\end{array}$ \\
\hline \multirow{3}{*}{\multicolumn{2}{|c|}{$\begin{array}{r}755 \\
756 \\
\text { Total upgradient }\end{array}$}} & 72 & 9,650 & 695,765 & $U$ & I & 1 & 1 & I & I & I & I & I & I & I & 1 & $\mathrm{NI}$ & \\
\hline & & 71 & 9,730 & 692,776 & $U$ & I & I & I & I & I & I & I & I & I & I & I & $\mathrm{NI}$ & \\
\hline & & 970 & 6,190 & $5,999,927$ & C & & & & & & & & & & & & & \\
\hline \multirow[t]{5}{*}{$43 \& 44$} & 778 & 51 & 6,000 & 306,000 & $\mathrm{~L}$ & 1 & 1 & 1 & 1 & 1 & 1 & 1 & I & 1 & 1 & 1 & $\mathrm{NI}$ & \\
\hline & 775 & 11 & 3,000 & 33,900 & $\mathrm{~L}$ & $\mathrm{NI}$ & $\mathrm{NI}$ & $\mathrm{NI}$ & $\mathrm{NI}$ & $\mathrm{NI}$ & $\mathrm{NI}$ & 1 & 1 & 1 & $\mathrm{NI}$ & I & $\mathrm{NI}$ & \\
\hline & $775-1$ & 63 & 4,000 & 252,400 & $\mathrm{~L}$ & $\mathrm{NI}$ & 1 & $\mathrm{NI}$ & 1 & $\mathrm{NI}$ & $\mathrm{NI}$ & $\mathrm{NI}$ & $\mathrm{NI}$ & $\mathrm{NI}$ & $\mathrm{NI}$ & $\mathrm{NI}$ & $\mathrm{NI}$ & \\
\hline & 755 & 72 & 5,000 & 360,500 & $\mathrm{~L}$ & 1 & 1 & 1 & I & 1 & 1 & 1 & 1 & 1 & 1 & I & $\mathrm{NI}$ & \\
\hline & 756 & 71 & 7,000 & 498,400 & $\mathrm{~L}$ & 1 & 1 & 1 & 1 & 1 & 1 & I & 1 & I & 1 & 1 & $\mathrm{NI}$ & \\
\hline \multicolumn{2}{|c|}{ Total lateral } & 269 & 5,390 & $1,451,200$ & c & & & & & & & & & & & & & \\
\hline \multirow[t]{6}{*}{45} & 804 & 348 & 4,780 & $1,664,396$ & $U$ & $\mathrm{NI}$ & $\mathrm{NI}$ & $\mathrm{NI}$ & $\mathrm{NI}$ & $\mathrm{NI}$ & $\mathrm{NI}$ & $\mathrm{NI}$ & $\mathrm{NI}$ & $\mathrm{NI}$ & $\mathrm{NI}$ & $\mathrm{NI}$ & $\mathrm{NI}$ & I- 89 \& prior \\
\hline & 805 & 63 & 6,230 & 389,998 & $U$ & $\mathrm{NI}$ & $\mathrm{NI}$ & $\mathrm{NI}$ & $\mathrm{NI}$ & $\mathrm{NI}$ & $\mathrm{NI}$ & $\mathrm{NI}$ & $\mathrm{NI}$ & $\mathrm{NI}$ & $\mathrm{NI}$ & $\mathrm{NI}$ & $\mathrm{NI}$ & I- 89 \& prior \\
\hline & 806 & 93 & 6,110 & 567,619 & $U$ & 1 & 1 & 1 & $\mathrm{NI}$ & $\mathrm{NI}$ & $\mathrm{NI}$ & $\mathrm{NI}$ & $\mathrm{NI}$ & $\mathrm{NI}$ & $\mathrm{NI}$ & $\mathrm{NI}$ & $\mathrm{NI}$ & \\
\hline & $900-A$ & 21 & 9,500 & 196,650 & $U$ & 1 & I & I & 1 & 1 & 1 & $\mathrm{NI}$ & $\mathrm{NI}$ & $\mathrm{NI}$ & $\mathrm{NI}$ & I & $\mathrm{NI}$ & \\
\hline & $900-B$ & 20 & 8,290 & 166,629 & $U$ & $\mathrm{NI}$ & 1 & I & I & I & 1 & $\mathrm{NI}$ & $\mathrm{NI}$ & $\mathrm{NI}$ & $\mathrm{NI}$ & I & $\mathrm{NI}$ & \\
\hline & 808 & 0 & 7,670 & 0 & $U$ & 1 & 1 & 1 & 1 & 1 & 1 & 1 & 1 & 1 & 1 & I & I & \\
\hline \multicolumn{2}{|c|}{ Total upgradient } & 545 & 5,480 & $2,985,292$ & C & & & & & & & & & & & & & \\
\hline & 793 & 107 & 2,180 & 232,388 & L & 1 & 1 & $\mathrm{NI}$ & $\mathrm{NI}$ & $\mathrm{NI}$ & $\mathrm{NI}$ & $\mathrm{NI}$ & I & $\mathrm{NI}$ & $\mathrm{NI}$ & 1 & $\mathrm{NI}$ & \\
\hline & 794-1 & 54 & 2,740 & 146,864 & $\mathrm{~L}$ & I & 1 & 1 & I & $\mathrm{NI}$ & 1 & 1 & I & I & $\mathrm{NI}$ & I & $\mathrm{NI}$ & \\
\hline \multicolumn{2}{|c|}{ Total lateral } & 160 & 2,370 & 379,252 & & & & & & & & & & & & & & \\
\hline & 795 & 71 & 2,500 & 178,250 & $D$ & 1 & 1 & $\mathrm{NI}$ & $\mathrm{NI}$ & $\mathrm{NI}$ & $\mathrm{NI}$ & $\mathrm{NI}$ & I & $\mathrm{NI}$ & $\mathrm{NI}$ & $\mathrm{NI}$ & $\mathrm{NI}$ & \\
\hline & 778 & 51 & 5,360 & 273,360 & $D$ & I & I & 1 & I & 1 & 1 & 1 & 1 & 1 & 1 & 1 & $\mathrm{NI}$ & \\
\hline & $778 \mathrm{~A}, \mathrm{~B}$ & 15 & 6,900 & 103,500 & $\mathrm{D}$ & $\mathrm{NI}$ & $\mathrm{NI}$ & $\mathrm{NI}$ & $\mathrm{NI}$ & $\mathrm{NI}$ & $\mathrm{NI}$ & $\mathrm{NI}$ & $\mathrm{NI}$ & $\mathrm{NI}$ & $\mathrm{NI}$ & $\mathrm{NI}$ & $\mathrm{NI}$ & $\mathrm{NI}$ from 87 \\
\hline \multirow{2}{*}{\multicolumn{2}{|c|}{$\begin{array}{l}\text { Total downgradient } \\
\text { Site total }\end{array}$}} & 137 & 4,040 & 555,110 & C & & & & & & & & & & & & & \\
\hline & & 842 & & & & & & & & & & & & & & & & \\
\hline \multirow[t]{6}{*}{$46 \& 47$} & 804 & 348 & 3,650 & $1,270,930$ & $\mathrm{D}$ & $\mathrm{NI}$ & $\mathrm{NI}$ & $\mathrm{NI}$ & $\mathrm{NI}$ & $\mathrm{NI}$ & $\mathrm{NI}$ & $\mathrm{NI}$ & $\mathrm{NI}$ & $\mathrm{NI}$ & $\mathrm{NI}$ & $\mathrm{NI}$ & $\mathrm{NI}$ & I-89 \& prior \\
\hline & 805 & 63 & 1,200 & 75,120 & $D$ & $\mathrm{NI}$ & $\mathrm{NI}$ & $\mathrm{NI}$ & $\mathrm{NI}$ & $\mathrm{NI}$ & $\mathrm{NI}$ & $\mathrm{NI}$ & $\mathrm{NI}$ & $\mathrm{NI}$ & $\mathrm{NI}$ & $\mathrm{NI}$ & $\mathrm{NI}$ & I-89 \& prior \\
\hline & 806 & 93 & 4,430 & 411,547 & $D$ & 1 & 1 & 1 & $\mathrm{NI}$ & 1 & $\mathrm{NI}$ & $\mathrm{NI}$ & $\mathrm{NI}$ & $\mathrm{NI}$ & $\mathrm{NI}$ & $\mathrm{NI}$ & $\mathrm{NI}$ & \\
\hline & $900-A$ & 21 & 4,380 & 90,666 & $D$ & I & 1 & I & II & 1 & 1 & $\mathrm{NI}$ & $\mathrm{NI}$ & $\mathrm{NI}$ & $\mathrm{NI}$ & 1 & $\mathrm{NI}$ & \\
\hline & $900-B$ & 20 & 4,850 & 97,485 & $D$ & $\mathrm{NI}$ & 1 & 1 & 1 & 1 & 1 & $\mathrm{NI}$ & $\mathrm{NI}$ & $\mathrm{NI}$ & $\mathrm{NI}$ & I & $\mathrm{NI}$ & \\
\hline & 808 & 0 & 3,380 & 0 & $\mathrm{D}$ & 1 & 1 & 1 & 1 & 1 & 1 & 1 & 1 & I & I & I & 1 & \\
\hline \multicolumn{2}{|c|}{ Total downgradient } & 545 & 3,570 & $1,945,748$ & C & & & & & & & & & & & & & \\
\hline
\end{tabular}




\begin{tabular}{|c|c|c|c|c|c|c|c|c|c|c|c|c|c|c|c|c|c|c|}
\hline $\begin{array}{c}\text { Site } \\
\text { number } \\
\text { (figure 3) }\end{array}$ & $\begin{array}{c}\text { TCID } \\
\text { serial } \\
\text { number }\end{array}$ & $\begin{array}{c}\text { Parcel } \\
\text { size } \\
\text { (acres) }^{a}\end{array}$ & $\begin{array}{l}\text { Average } \\
\text { distance } \\
\text { of parcel } \\
\text { from well } \\
\text { (feet) }\end{array}$ & $\begin{array}{c}\text { Acres } \\
\text { times } \\
\text { distance }^{b}\end{array}$ & $\begin{array}{l}\text { Gradient } \\
\text { direction }\end{array}$ & 1992 & 1993 & 1994 & 1995 & 1996 & 1997 & 1998 & 1999 & 2000 & 2001 & 2002 & 2003 & $\begin{array}{c}\text { Irrigation } \\
\text { prior to } \\
1992 \\
\end{array}$ \\
\hline \multirow[t]{5}{*}{50} & 674 & 91 & 2,250 & 205,425 & U & 1 & I & 1 & 1 & $\mathrm{NI}$ & $\mathrm{NI}$ & $\mathrm{NI}$ & $\mathrm{NI}$ & $\mathrm{NI}$ & $\mathrm{NI}$ & I & $\mathrm{NI}$ & \\
\hline & 670 & 84 & 1,420 & 118,854 & $U$ & $\mathrm{NI}$ & 1 & 1 & 1 & $\mathrm{NI}$ & $\mathrm{NI}$ & $\mathrm{NI}$ & $\mathrm{NI}$ & $\mathrm{NI}$ & $\mathrm{NI}$ & $\mathrm{NI}$ & $\mathrm{NI}$ & \\
\hline & $783-1$ & 0 & 1,600 & 0 & $\mathrm{U}$ & 1 & 1 & 1 & 1 & $\mathrm{NI}$ & 1 & 1 & I & I & I & I & 1 & \\
\hline & 668 & 23 & 8,000 & 180,800 & $U$ & 1 & $\mathrm{NI}$ & 1 & $\mathrm{NI}$ & $\mathrm{NI}$ & $\mathrm{NI}$ & 1 & 1 & I & 1 & 1 & $\mathrm{NI}$ & \\
\hline & $673-1$ & 32 & 0 & 0 & $U$ & I & $\mathrm{NI}$ & $\mathrm{NI}$ & $\mathrm{NI}$ & $\mathrm{NI}$ & $\mathrm{NI}$ & $\mathrm{NI}$ & $\mathrm{NI}$ & $\mathrm{NI}$ & $\mathrm{NI}$ & $\mathrm{NI}$ & $\mathrm{NI}$ & \\
\hline \multicolumn{2}{|c|}{ Total upgradient } & 230 & 2,200 & 505,079 & c & & & & & & & & & & & & & \\
\hline \multirow[t]{2}{*}{60} & $4 \mathrm{~A} 12$ & 119 & 7,000 & 834,400 & $\mathrm{~L}$ & 1 & 1 & 1 & 1 & 1 & $\mathrm{NI}$ & I & 1 & I & $\mathrm{NI}$ & $\mathrm{NI}$ & $\mathrm{NI}$ & \\
\hline & $4 \mathrm{~A} 05$ & 135 & 7,000 & 947,100 & $L$ & 1 & 1 & 1 & 1 & I & 1 & 1 & 1 & 1 & 1 & 1 & $\mathrm{NI}$ & \\
\hline \multicolumn{2}{|c|}{ Total lateral } & 255 & 7,000 & $1,781,500$ & c & & & & & & & & & & & & & \\
\hline \multirow[t]{3}{*}{$62 \& 63$} & $4 \mathrm{~A} 10$ & 260 & 1,580 & 410,010 & $U$ & I & 1 & 1 & 1 & I & I & $\mathrm{NI}$ & 1 & $\mathrm{NI}$ & $\mathrm{NI}$ & $\mathrm{NI}$ & $\mathrm{NI}$ & \\
\hline & $303-1$ & 38 & 3,500 & 131,600 & $U$ & $\mathrm{NI}$ & 1 & $\mathrm{NI}$ & $\mathrm{NI}$ & $\mathrm{NI}$ & $\mathrm{NI}$ & $\mathrm{NI}$ & $\mathrm{NI}$ & $\mathrm{NI}$ & $\mathrm{NI}$ & $\mathrm{NI}$ & $\mathrm{NI}$ & \\
\hline & $4 \mathrm{~A} 12$ & 119 & 5,450 & 649,640 & $U$ & 1 & 1 & I & 1 & 1 & $\mathrm{NI}$ & 1 & 1 & I & $\mathrm{NI}$ & $\mathrm{NI}$ & $\mathrm{NI}$ & \\
\hline \multicolumn{2}{|c|}{ Total upgradient } & 416 & 2,860 & $1,191,250$ & c & & & & & & & & & & & & & \\
\hline & $318-1 \& 2$ & 66 & 390 & 25,623 & L & 1 & 1 & 1 & 1 & $\mathrm{NI}$ & I & $\mathrm{NI}$ & 1 & I & $\mathrm{NI}$ & 1 & $\mathrm{NI}$ & \\
\hline & 4A05 & 135 & 5,850 & 791,505 & L & 1 & 1 & 1 & 1 & 1 & I & 1 & I & I & 1 & 1 & $\mathrm{NI}$ & \\
\hline & 302 & 66 & 2,430 & 159,651 & $L$ & $\mathrm{NI}$ & I & $\mathrm{NI}$ & $\mathrm{NI}$ & $\mathrm{NI}$ & $\mathrm{NI}$ & $\mathrm{NI}$ & $\mathrm{NI}$ & $\mathrm{NI}$ & $\mathrm{NI}$ & $\mathrm{NI}$ & $\mathrm{NI}$ & \\
\hline \multicolumn{2}{|c|}{ Total lateral } & 267 & 3,660 & 976,779 & C & & & & & & & & & & & & & \\
\hline & 317 & 98 & 1,020 & 99,960 & $\mathrm{D}$ & $\mathrm{NI}$ & 1 & $\mathrm{NI}$ & $\mathrm{NI}$ & $\mathrm{NI}$ & $\mathrm{NI}$ & $\mathrm{NI}$ & $\mathrm{NI}$ & $\mathrm{NI}$ & $\mathrm{NI}$ & $\mathrm{NI}$ & $\mathrm{NI}$ & \\
\hline & 328 & 74 & 3,400 & 252,960 & $\mathrm{D}$ & 1 & $\mathrm{NI}$ & $\mathrm{NI}$ & $\mathrm{NI}$ & $\mathrm{NI}$ & $\mathrm{NI}$ & $\mathrm{NI}$ & $\mathrm{NI}$ & $\mathrm{NI}$ & $\mathrm{NI}$ & $\mathrm{NI}$ & $\mathrm{NI}$ & \\
\hline & 326 & 146 & 6,180 & 902,280 & $\mathrm{D}$ & $\mathrm{NI}$ & $\mathrm{NI}$ & $\mathrm{NI}$ & $\mathrm{NI}$ & $\mathrm{NI}$ & $\mathrm{NI}$ & $\mathrm{NI}$ & $\mathrm{NI}$ & $\mathrm{NI}$ & $\mathrm{NI}$ & $\mathrm{NI}$ & $\mathrm{NI}$ & I-90 \& prior \\
\hline \multicolumn{2}{|c|}{ Total downgradient } & 318 & 3,940 & $1,255,200$ & c & & & & & & & & & & & & & \\
\hline \multicolumn{2}{|c|}{ Site total } & 1,001 & & & & & & & & & & & & & & & & \\
\hline \multirow[t]{4}{*}{64} & $305-1$ & 223 & 7,130 & $1,590,703$ & $\mathrm{U}$ & 1 & 1 & 1 & 1 & $\mathrm{NI}$ & 1 & 1 & 1 & 1 & $\mathrm{NI}$ & $\mathrm{NI}$ & $\mathrm{NI}$ & \\
\hline & $303-1$ & 38 & 3,000 & 112,800 & $\mathrm{U}$ & $\mathrm{NI}$ & 1 & $\mathrm{NI}$ & $\mathrm{NI}$ & $\mathrm{NI}$ & $\mathrm{NI}$ & $\mathrm{NI}$ & $\mathrm{NI}$ & $\mathrm{NI}$ & $\mathrm{NI}$ & $\mathrm{NI}$ & $\mathrm{NI}$ & \\
\hline & 304 & 308 & 1,200 & 369,240 & $\mathrm{U}$ & $\mathrm{NI}$ & 1 & $\mathrm{NI}$ & 1 & 1 & 1 & 1 & $\mathrm{NI}$ & $\mathrm{NI}$ & $\mathrm{NI}$ & $\mathrm{NI}$ & $\mathrm{NI}$ & \\
\hline & 24 & 178 & 1,020 & 181,254 & $U$ & $\mathrm{NI}$ & 1 & $\mathrm{NI}$ & $\mathrm{NI}$ & $\mathrm{NI}$ & $\mathrm{NI}$ & $\mathrm{NI}$ & $\mathrm{NI}$ & $\mathrm{NI}$ & $\mathrm{NI}$ & $\mathrm{NI}$ & $\mathrm{NI}$ & \\
\hline \multicolumn{2}{|c|}{ Total upgradient } & 746 & 3,020 & $2,253,997$ & c & & & & & & & & & & & & & \\
\hline & $24-1$ & 115 & 3,190 & 365,893 & $\mathrm{~L}$ & $\mathrm{NI}$ & 1 & 1 & 1 & $\mathrm{NI}$ & $\mathrm{NI}$ & $\mathrm{NI}$ & $\mathrm{NI}$ & $\mathrm{NI}$ & $\mathrm{NI}$ & $\mathrm{NI}$ & $\mathrm{NI}$ & \\
\hline & 307 & 0 & 4,500 & 0 & $\mathrm{~L}$ & 1 & 1 & 1 & 1 & 1 & 1 & $\mathrm{NI}$ & 1 & 1 & 1 & 1 & 1 & \\
\hline Total la & ateral & 115 & 3,190 & 365,893 & c & & & & & & & & & & & & & \\
\hline
\end{tabular}


Appendix B.-Continued.

\begin{tabular}{|c|c|c|c|c|c|c|c|c|c|c|c|c|c|c|c|c|c|c|}
\hline $\begin{array}{c}\text { Site } \\
\text { number } \\
\text { (figure 3) }\end{array}$ & $\begin{array}{c}\text { TCID } \\
\text { serial } \\
\text { number }\end{array}$ & $\begin{array}{c}\text { Parcel } \\
\text { size } \\
\text { (acres) }^{a}\end{array}$ & $\begin{array}{l}\text { Average } \\
\text { distance } \\
\text { of parcel } \\
\text { from well } \\
\text { (feet) }\end{array}$ & \multicolumn{2}{|l|}{$\begin{array}{c}\text { Acres } \\
\text { times } \\
\text { distance }^{b}\end{array}$} & 1992 & 1993 & 1994 & 1995 & 1996 & 1997 & 1998 & 1999 & 2000 & 2001 & 2002 & 2003 & $\begin{array}{c}\text { Irrigation } \\
\text { prior to } \\
1992 \\
\end{array}$ \\
\hline & $25-1$ & 170 & 1,600 & 271,200 & D & 1 & I & 1 & 1 & $\mathrm{NI}$ & $\mathrm{NI}$ & $\mathrm{NI}$ & $\mathrm{NI}$ & $\mathrm{NI}$ & $\mathrm{NI}$ & $\mathrm{NI}$ & $\mathrm{NI}$ & \\
\hline & 316 & 0 & 5,300 & 0 & $D$ & $\mathrm{NI}$ & I & 1 & 1 & $\mathrm{NI}$ & $\mathrm{NI}$ & $\mathrm{NI}$ & $\mathrm{NI}$ & $\mathrm{NI}$ & $\mathrm{NI}$ & 1 & 1 & \\
\hline & $24-3-4$ & 157 & 9,000 & $1,409,400$ & $\mathrm{D}$ & $\mathrm{NI}$ & $\mathrm{NI}$ & $\mathrm{NI}$ & $\mathrm{NI}$ & $\mathrm{NI}$ & $\mathrm{NI}$ & $\mathrm{NI}$ & $\mathrm{NI}$ & $\mathrm{NI}$ & $\mathrm{NI}$ & $\mathrm{NI}$ & $\mathrm{NI}$ & |-89-91 \\
\hline & $24-3-1$ & 100 & 5,000 & 500,000 & $\mathrm{D}$ & $\mathrm{NI}$ & $\mathrm{NI}$ & $\mathrm{NI}$ & $\mathrm{NI}$ & $\mathrm{NI}$ & $\mathrm{NI}$ & $\mathrm{NI}$ & $\mathrm{NI}$ & $\mathrm{NI}$ & $\mathrm{NI}$ & $\mathrm{NI}$ & $\mathrm{NI}$ & I-89-91 \\
\hline & $24-3-3$ & 49 & 5,710 & 280,932 & $D$ & $\mathrm{NI}$ & $\mathrm{NI}$ & $\mathrm{NI}$ & $\mathrm{NI}$ & $\mathrm{NI}$ & $\mathrm{NI}$ & $\mathrm{NI}$ & $\mathrm{NI}$ & $\mathrm{NI}$ & $\mathrm{NI}$ & $\mathrm{NI}$ & $\mathrm{NI}$ & |-89-91 \\
\hline \multicolumn{2}{|c|}{ Total downgradient } & 475 & 5,180 & $2,461,532$ & c & & & & & & & & & & & & & \\
\hline \multicolumn{2}{|c|}{ Site total } & 1,336 & & & & & & & & & & & & & & & & \\
\hline \multirow[t]{2}{*}{65} & 311 & 181 & 2,870 & 520,044 & $\mathrm{D}$ & 1 & 1 & 1 & 1 & 1 & I & I & 1 & I & 1 & 1 & $\mathrm{NI}$ & \\
\hline & 310 & 134 & 5,620 & 751,956 & $\mathrm{D}$ & 1 & 1 & 1 & 1 & I & 1 & 1 & 1 & 1 & 1 & 1 & $\mathrm{NI}$ & \\
\hline \multicolumn{2}{|c|}{ Total downgradient } & 315 & 4,040 & $1,272,000$ & c & & & & & & & & & & & & & \\
\hline \multirow[t]{3}{*}{66} & 170 & 139 & 1,310 & 182,090 & $U$ & 1 & I & 1 & 1 & I & 1 & I & 1 & 1 & I & $\mathrm{NI}$ & $\mathrm{NI}$ & \\
\hline & 2143 & 112 & 1,100 & 122,760 & $U$ & 1 & I & 1 & 1 & 1 & 1 & I & 1 & I & 1 & 1 & $\mathrm{NI}$ & \\
\hline & 171 & 59 & 1,480 & 87,172 & $U$ & I & 1 & 1 & 1 & 1 & 1 & 1 & I & I & I & 1 & $\mathrm{NI}$ & \\
\hline \multicolumn{2}{|c|}{ Total upgradient } & 310 & 1,270 & 392,022 & C & & & & & & & & & & & & & \\
\hline \multirow[t]{8}{*}{70} & $6-A-1$ & 81 & 4,270 & 346,724 & $U$ & I & 1 & 1 & 1 & $\mathrm{NI}$ & $\mathrm{NI}$ & $\mathrm{NI}$ & 1 & $\mathrm{NI}$ & I & $\mathrm{NI}$ & $\mathrm{NI}$ & \\
\hline & $6-A-2$ & 32 & 4,300 & 139,320 & $U$ & 1 & I & 1 & 1 & $\mathrm{NI}$ & $\mathrm{NI}$ & $\mathrm{NI}$ & 1 & I & $\mathrm{NI}$ & $\mathrm{NI}$ & $\mathrm{NI}$ & \\
\hline & $6-A-3$ & 33 & 3,140 & 102,992 & $U$ & 1 & 1 & 1 & $\mathrm{NI}$ & $\mathrm{NI}$ & $\mathrm{NI}$ & $\mathrm{NI}$ & 1 & $\mathrm{NI}$ & $\mathrm{NI}$ & $\mathrm{NI}$ & $\mathrm{NI}$ & \\
\hline & $6-A-4$ & 95 & 3,320 & 314,072 & $U$ & 1 & 1 & 1 & 1 & $\mathrm{NI}$ & $\mathrm{NI}$ & $\mathrm{NI}$ & 1 & $\mathrm{NI}$ & $\mathrm{NI}$ & $\mathrm{NI}$ & $\mathrm{NI}$ & \\
\hline & $13-1$ & 34 & 2,220 & 74,370 & $U$ & & 1 & 1 & $\mathrm{NI}$ & $\mathrm{NI}$ & $\mathrm{NI}$ & $\mathrm{NI}$ & 1 & I & $\mathrm{NI}$ & $\mathrm{NI}$ & $\mathrm{NI}$ & \\
\hline & $6-12-$ & 44 & 9,400 & 412,660 & $U$ & & 1 & 1 & 1 & $\mathrm{NI}$ & $\mathrm{NI}$ & 1 & 1 & 1 & $\mathrm{NI}$ & 1 & $\mathrm{NI}$ & \\
\hline & $6-10-$ & 81 & 4,740 & 385,362 & $U$ & 1 & I & 1 & 1 & 1 & I & I & 1 & 1 & 1 & 1 & $\mathrm{NI}$ & \\
\hline & $18-1 \&-1-A$ & 78 & 2,400 & 186,960 & $U$ & 1 & 1 & 1 & $\mathrm{NI}$ & $\mathrm{NI}$ & $\mathrm{NI}$ & $\mathrm{NI}$ & $\mathrm{NI}$ & $\mathrm{NI}$ & $\mathrm{NI}$ & $\mathrm{NI}$ & $\mathrm{NI}$ & \\
\hline \multicolumn{2}{|c|}{ Total upgradient } & 478 & 4,110 & $1,962,460$ & c & & & & & & & & & & & & & \\
\hline & 13-2 & 33 & 2,910 & 95,739 & L & 1 & 1 & 1 & 1 & $\mathrm{NI}$ & $\mathrm{NI}$ & $\mathrm{NI}$ & 1 & $\mathrm{NI}$ & $\mathrm{NI}$ & $\mathrm{NI}$ & $\mathrm{NI}$ & \\
\hline & 45 & 109 & 1,450 & 158,485 & $L$ & 1 & $\mathrm{NI}$ & 1 & $\mathrm{NI}$ & $\mathrm{NI}$ & $\mathrm{NI}$ & $\mathrm{NI}$ & $\mathrm{NI}$ & $\mathrm{NI}$ & $\mathrm{NI}$ & $\mathrm{NI}$ & $\mathrm{NI}$ & \\
\hline & $45-1$ & 32 & 1,020 & 32,538 & $L$ & 1 & $\mathrm{NI}$ & 1 & $\mathrm{NI}$ & 1 & $\mathrm{NI}$ & $\mathrm{NI}$ & $\mathrm{NI}$ & $\mathrm{NI}$ & $\mathrm{NI}$ & $\mathrm{NI}$ & $\mathrm{NI}$ & \\
\hline & 15 & 136 & 480 & 65,280 & $L$ & 1 & I & 1 & I & 1 & $\mathrm{NI}$ & $\mathrm{NI}$ & $\mathrm{NI}$ & $\mathrm{NI}$ & $\mathrm{NI}$ & $\mathrm{NI}$ & $\mathrm{NI}$ & \\
\hline Total I & lateral & 310 & 1,140 & 352,042 & C & & & & & & & & & & & & & \\
\hline & $13-3$ & 37 & 1,660 & 60,922 & $\mathrm{D}$ & 1 & I & 1 & 1 & $\mathrm{NI}$ & $\mathrm{NI}$ & $\mathrm{NI}$ & 1 & 1 & $\mathrm{NI}$ & $\mathrm{NI}$ & $\mathrm{NI}$ & \\
\hline & 46 & 72 & 1,100 & 79,640 & $\mathrm{D}$ & $\mathrm{NI}$ & $\mathrm{NI}$ & 1 & $\mathrm{NI}$ & 1 & 1 & I & I & 1 & $\mathrm{NI}$ & $\mathrm{NI}$ & $\mathrm{NI}$ & \\
\hline & 20 & 368 & 2,790 & $1,025,883$ & $\mathrm{D}$ & $\mathrm{NI}$ & I & $\mathrm{NI}$ & $\mathrm{NI}$ & $\mathrm{NI}$ & $\mathrm{NI}$ & $\mathrm{NI}$ & $\mathrm{NI}$ & $\mathrm{NI}$ & $\mathrm{NI}$ & $\mathrm{NI}$ & $\mathrm{NI}$ & \\
\hline Total dowr & ngradient & 477 & 2,450 & $1,166,445$ & c & & & & & & & & & & & & & \\
\hline Site $t$ & total & 1,265 & & & & & & & & & & & & & & & & \\
\hline
\end{tabular}




\begin{tabular}{|c|c|c|c|c|c|c|c|c|c|c|c|c|c|c|c|c|c|c|}
\hline $\begin{array}{c}\text { Site } \\
\text { number } \\
\text { (figure 3) }\end{array}$ & $\begin{array}{c}\text { TCID } \\
\text { serial } \\
\text { number }\end{array}$ & $\begin{array}{c}\text { Parcel } \\
\text { size } \\
\text { (acres) }^{a}\end{array}$ & $\begin{array}{l}\text { of parcel } \\
\text { from well } \\
\text { (feet) }\end{array}$ & $\begin{array}{c}\text { Acres } \\
\text { times } \\
\text { distance }^{b}\end{array}$ & $\begin{array}{l}\text { Gradient } \\
\text { direction }\end{array}$ & 1992 & 1993 & 1994 & 1995 & 1996 & 1997 & 1998 & 1999 & 2000 & 2001 & 2002 & 2003 & $\begin{array}{c}\text { Irrigation } \\
\text { prior to } \\
1992 \\
\end{array}$ \\
\hline \multirow[t]{15}{*}{71} & $6-A-1$ & 81 & 12,000 & 974,400 & U & I & I & 1 & I & $\mathrm{NI}$ & $\mathrm{NI}$ & $\mathrm{NI}$ & I & $\mathrm{NI}$ & I & $\mathrm{NI}$ & $\mathrm{NI}$ & \\
\hline & $6-A-2$ & 32 & 12,600 & 408,240 & $U$ & I & I & I & 1 & $\mathrm{NI}$ & $\mathrm{NI}$ & $\mathrm{NI}$ & I & I & $\mathrm{NI}$ & $\mathrm{NI}$ & $\mathrm{NI}$ & \\
\hline & $6-A-3$ & 33 & 11,500 & 377,200 & $U$ & I & I & I & $\mathrm{NI}$ & $\mathrm{NI}$ & $\mathrm{NI}$ & $\mathrm{NI}$ & I & $\mathrm{NI}$ & $\mathrm{NI}$ & $\mathrm{NI}$ & $\mathrm{NI}$ & \\
\hline & $6-A-4$ & 95 & 10,800 & $1,021,680$ & $U$ & I & I & I & 1 & $\mathrm{NI}$ & $\mathrm{NI}$ & $\mathrm{NI}$ & I & $\mathrm{NI}$ & $\mathrm{NI}$ & $\mathrm{NI}$ & $\mathrm{NI}$ & \\
\hline & $13-1$ & 34 & 10,000 & 335,000 & $U$ & & I & I & $\mathrm{NI}$ & $\mathrm{NI}$ & $\mathrm{NI}$ & $\mathrm{NI}$ & I & I & $\mathrm{NI}$ & $\mathrm{NI}$ & $\mathrm{NI}$ & \\
\hline & $13-2$ & 33 & 10,500 & 345,450 & $U$ & 1 & 1 & 1 & 1 & $\mathrm{NI}$ & $\mathrm{NI}$ & $\mathrm{NI}$ & I & $\mathrm{NI}$ & $\mathrm{NI}$ & $\mathrm{NI}$ & $\mathrm{NI}$ & \\
\hline & $13-3$ & 37 & 7,700 & 282,590 & $U$ & I & I & I & 1 & $\mathrm{NI}$ & $\mathrm{NI}$ & $\mathrm{NI}$ & I & I & $\mathrm{NI}$ & $\mathrm{NI}$ & $\mathrm{NI}$ & \\
\hline & 20 & 368 & 6,500 & $2,390,050$ & $U$ & $\mathrm{NI}$ & I & $\mathrm{NI}$ & $\mathrm{NI}$ & $\mathrm{NI}$ & $\mathrm{NI}$ & $\mathrm{NI}$ & $\mathrm{NI}$ & $\mathrm{NI}$ & $\mathrm{NI}$ & $\mathrm{NI}$ & $\mathrm{NI}$ & \\
\hline & 6-12- & 44 & 17,700 & 777,030 & U & & I & I & 1 & $\mathrm{NI}$ & $\mathrm{NI}$ & 1 & I & I & $\mathrm{NI}$ & 1 & $\mathrm{NI}$ & \\
\hline & $6-10-$ & 81 & 11,000 & 894,300 & $U$ & 1 & 1 & 1 & 1 & 1 & 1 & I & 1 & I & 1 & 1 & $\mathrm{NI}$ & \\
\hline & 46 & 72 & 5,500 & 398,200 & $U$ & $\mathrm{NI}$ & $\mathrm{NI}$ & I & $\mathrm{NI}$ & I & I & I & I & I & $\mathrm{NI}$ & $\mathrm{NI}$ & $\mathrm{NI}$ & \\
\hline & $18-1 \&-1-A$ & 78 & 9,600 & 747,840 & $U$ & 1 & I & 1 & $\mathrm{NI}$ & $\mathrm{NI}$ & $\mathrm{NI}$ & $\mathrm{NI}$ & $\mathrm{NI}$ & $\mathrm{NI}$ & $\mathrm{NI}$ & $\mathrm{NI}$ & $\mathrm{NI}$ & \\
\hline & 45 & 109 & 6,800 & 743,240 & U & I & $\mathrm{NI}$ & I & $\mathrm{NI}$ & $\mathrm{NI}$ & $\mathrm{NI}$ & $\mathrm{NI}$ & $\mathrm{NI}$ & $\mathrm{NI}$ & $\mathrm{NI}$ & $\mathrm{NI}$ & $\mathrm{NI}$ & \\
\hline & $45-1$ & 32 & 8,400 & 267,960 & $U$ & I & $\mathrm{NI}$ & 1 & $\mathrm{NI}$ & 1 & $\mathrm{NI}$ & $\mathrm{NI}$ & $\mathrm{NI}$ & $\mathrm{NI}$ & $\mathrm{NI}$ & $\mathrm{NI}$ & $\mathrm{NI}$ & \\
\hline & 15 & 136 & 8,700 & $1,183,200$ & $U$ & 1 & I & I & I & I & $\mathrm{NI}$ & $\mathrm{NI}$ & $\mathrm{NI}$ & $\mathrm{NI}$ & $\mathrm{NI}$ & $\mathrm{NI}$ & $\mathrm{NI}$ & \\
\hline \multicolumn{2}{|c|}{ Total upgradient } & 1,265 & 8,820 & $11,146,380^{\mathrm{C}}$ & & & & & & & & & & & & & & \\
\hline \multirow[t]{3}{*}{72} & 23 & 158 & 6,200 & 978,360 & $U$ & 1 & I & 1 & 1 & I & nd & $\mathrm{NI}$ & nd & I & $\mathrm{NI}$ & $\mathrm{NI}$ & $\mathrm{NI}$ & \\
\hline & 2149 & 106 & 3,700 & 391,090 & $U$ & 1 & I & 1 & $\mathrm{NI}$ & $\mathrm{NI}$ & nd & $\mathrm{NI}$ & nd & $\mathrm{NI}$ & $\mathrm{NI}$ & $\mathrm{NI}$ & $\mathrm{NI}$ & \\
\hline & 2184 & 22 & 7,780 & 168,048 & $U$ & $\mathrm{NI}$ & $\mathrm{NI}$ & $\mathrm{NI}$ & $\mathrm{NI}$ & $\mathrm{NI}$ & nd & $\mathrm{NI}$ & nd & $\mathrm{NI}$ & $\mathrm{NI}$ & $\mathrm{NI}$ & $\mathrm{NI}$ & |- $90 \& 91$ \\
\hline
\end{tabular}

\begin{tabular}{l|l|l|l|} 
Total upgradient & 285 & 5,390 & $1,537,498$
\end{tabular}${ }^{\mathrm{C}}$

a Rounded to nearest acre.

${ }^{\mathrm{b}}$ Number calculated using non-rounded value for parcel size.

${ }^{\mathrm{c}}$ Value is sum for parcels in same direction 
Appendix C. Water-level hydrographs for monitoring wells for period of record at each well.

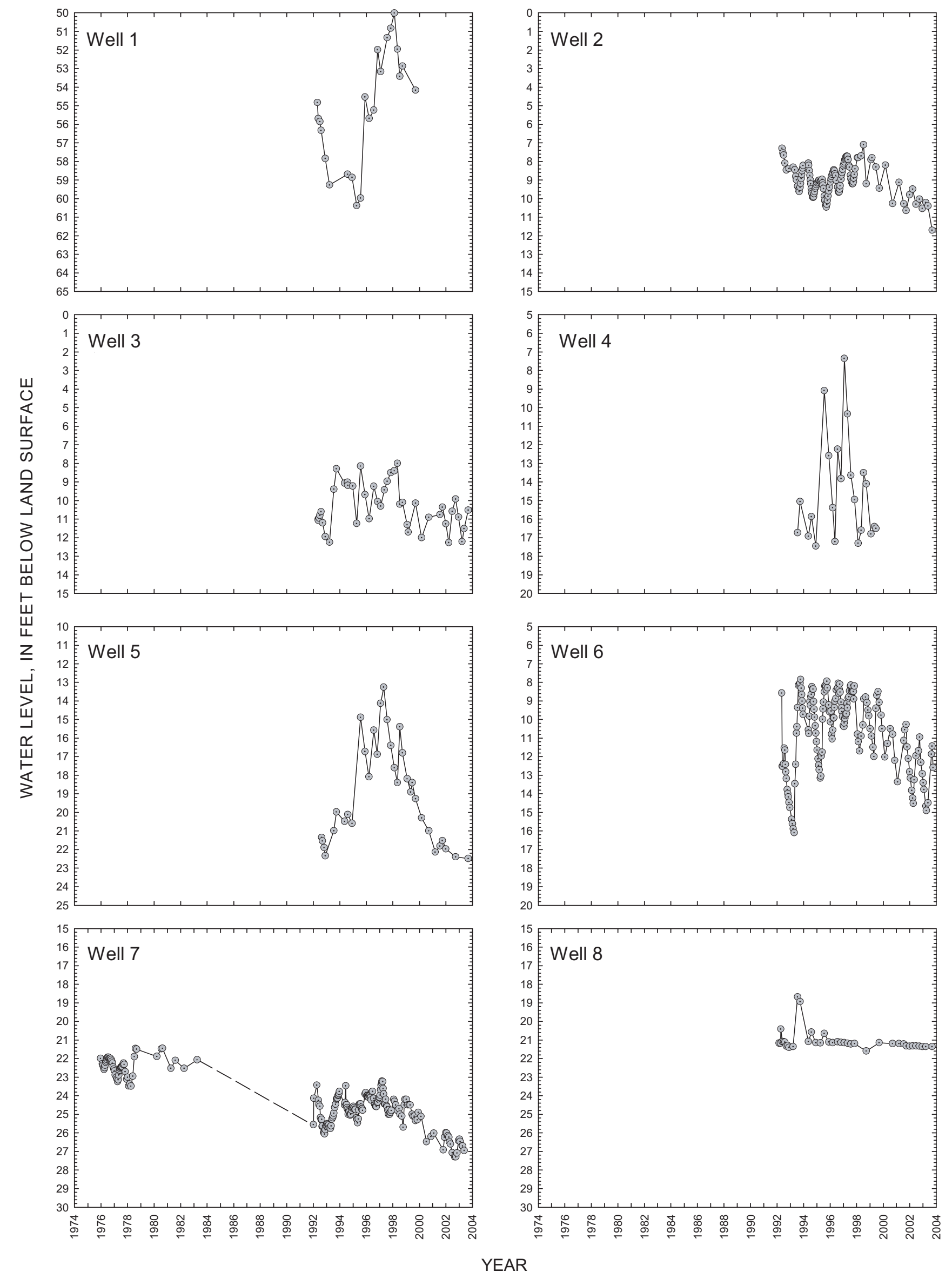


Appendix C. Changes in water levels at selected wells from the early 1990's and mid-1970's to 2003--Continued.
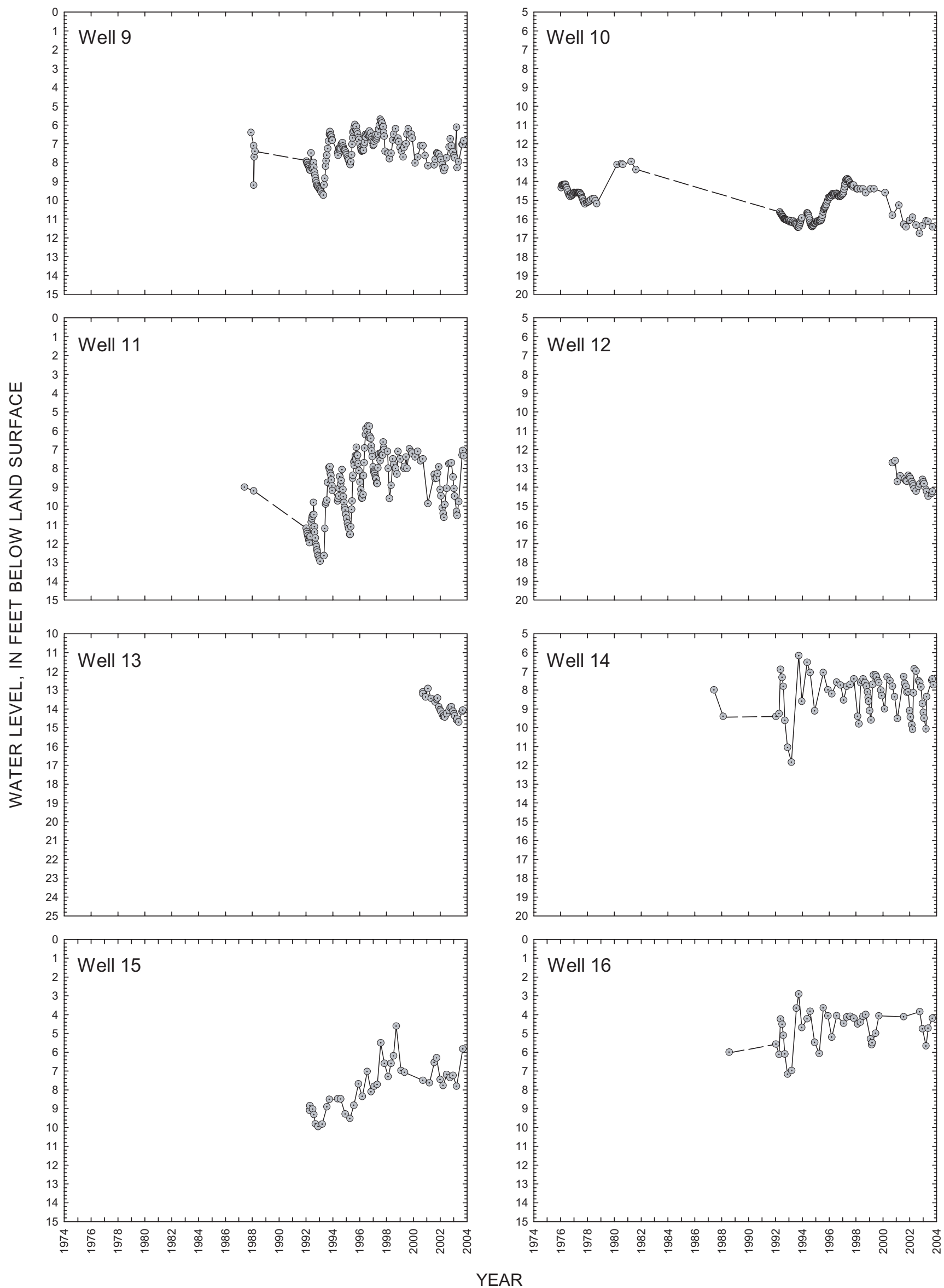
Appendix C. Changes in water levels at selected wells from the early 1990's and mid-1970's to 2003--Continued.
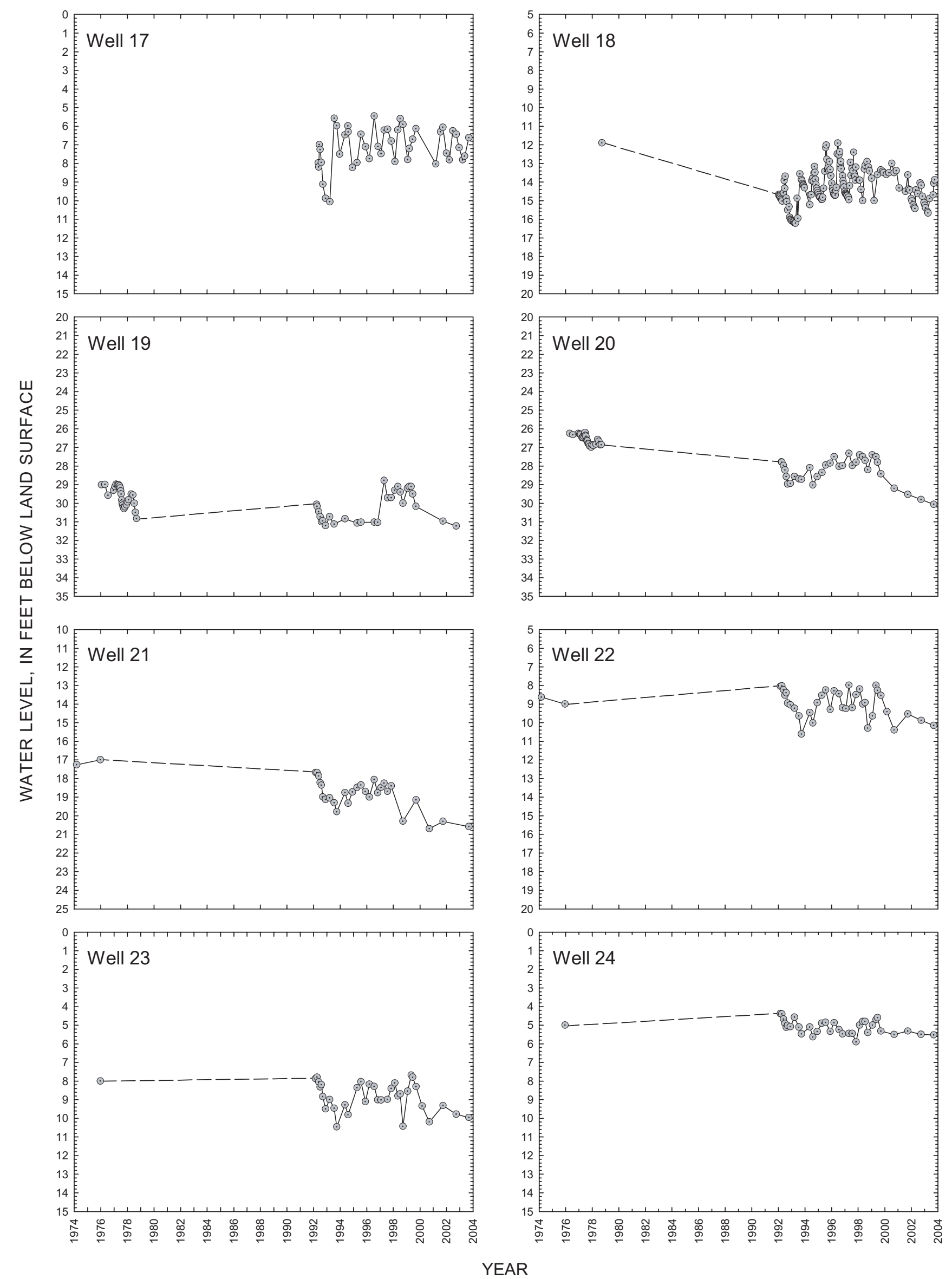
Appendix C. Changes in water levels at selected wells from the early 1990's and mid-1970's to 2003--Continued.
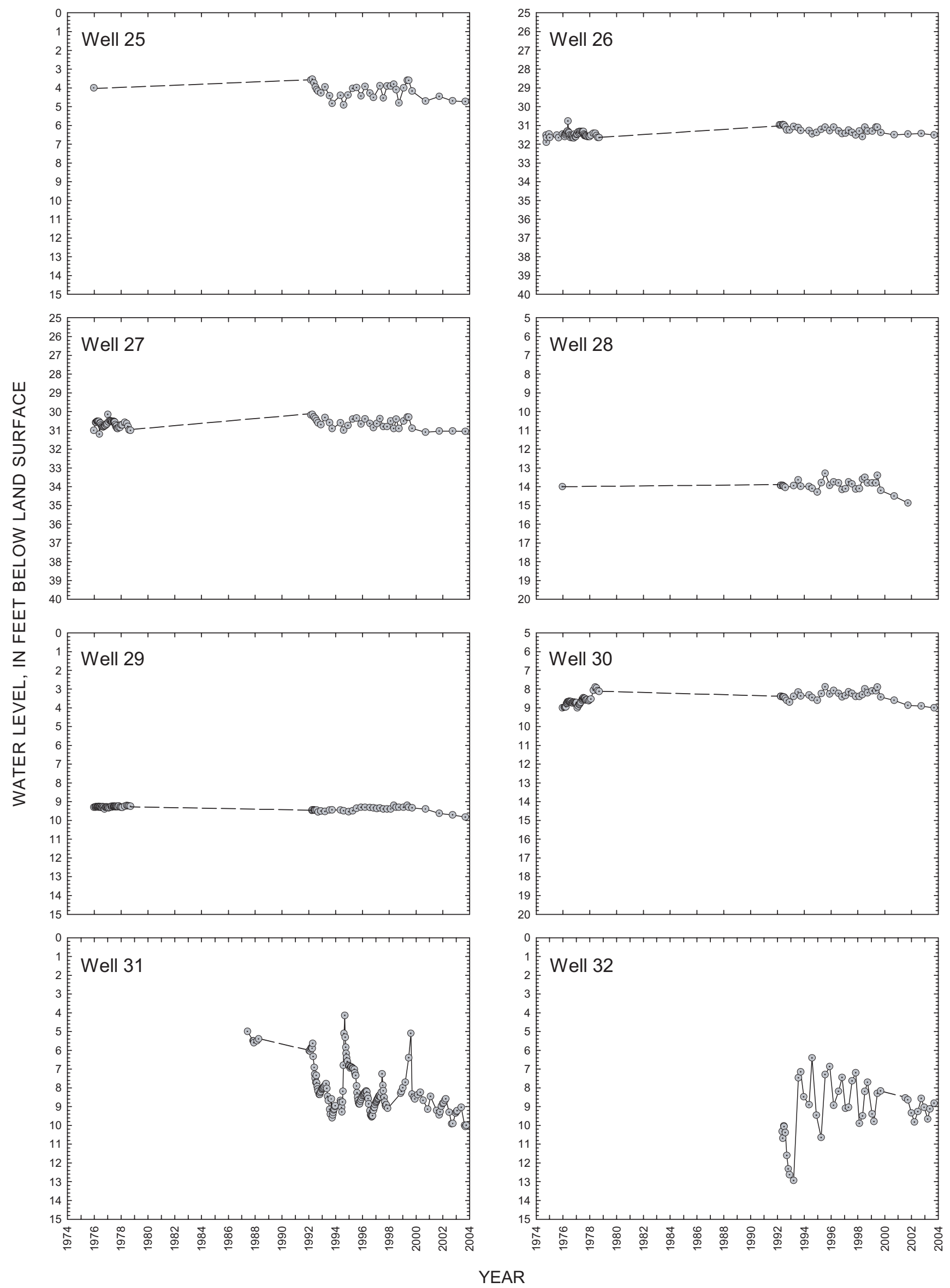
Appendix C. Changes in water levels at selected wells from the early 1990's and mid-1970's to 2003--Continued.
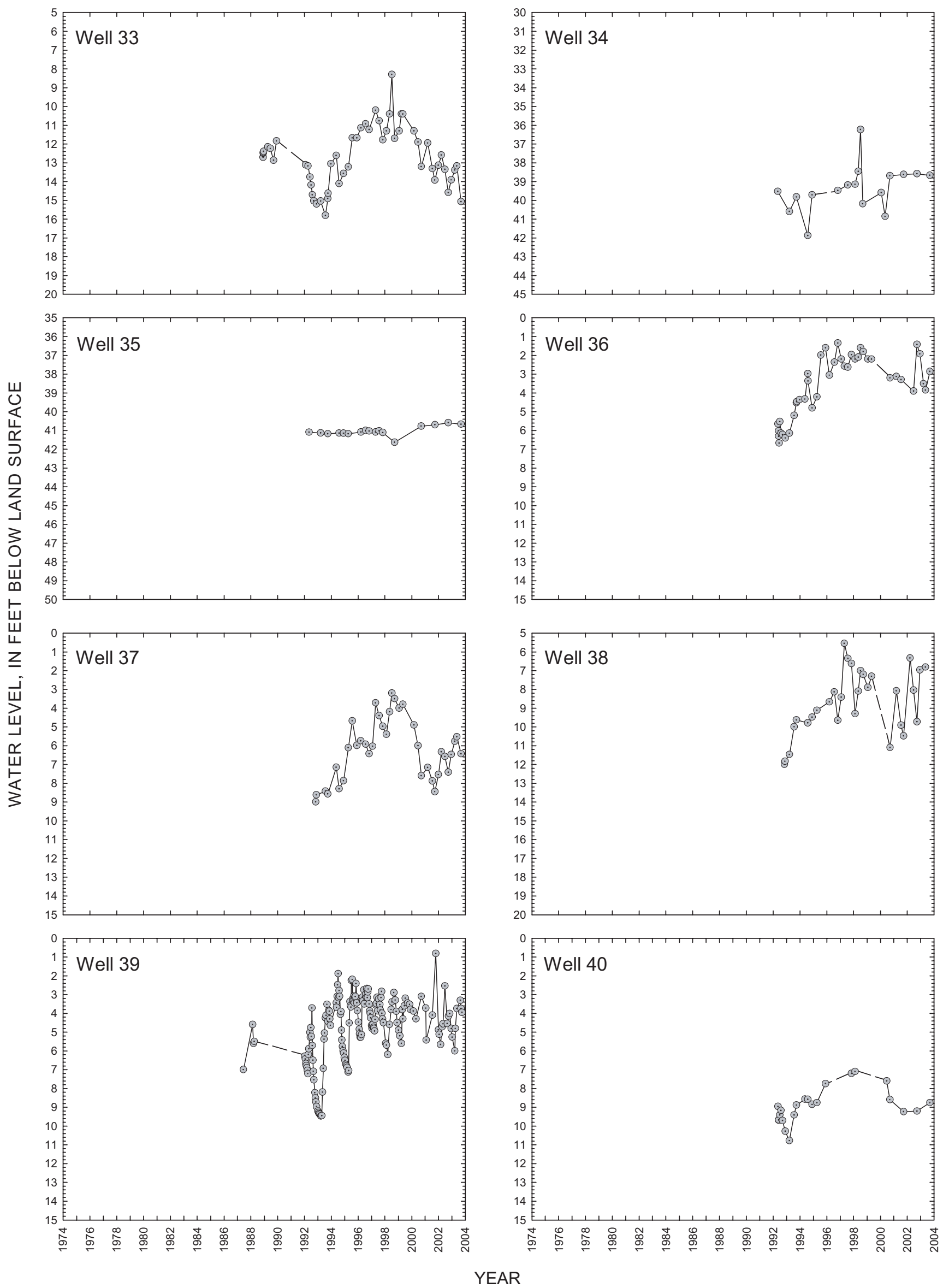
Appendix C. Changes in water levels at selected wells from the early 1990's and mid-1970's to 2003--Continued.

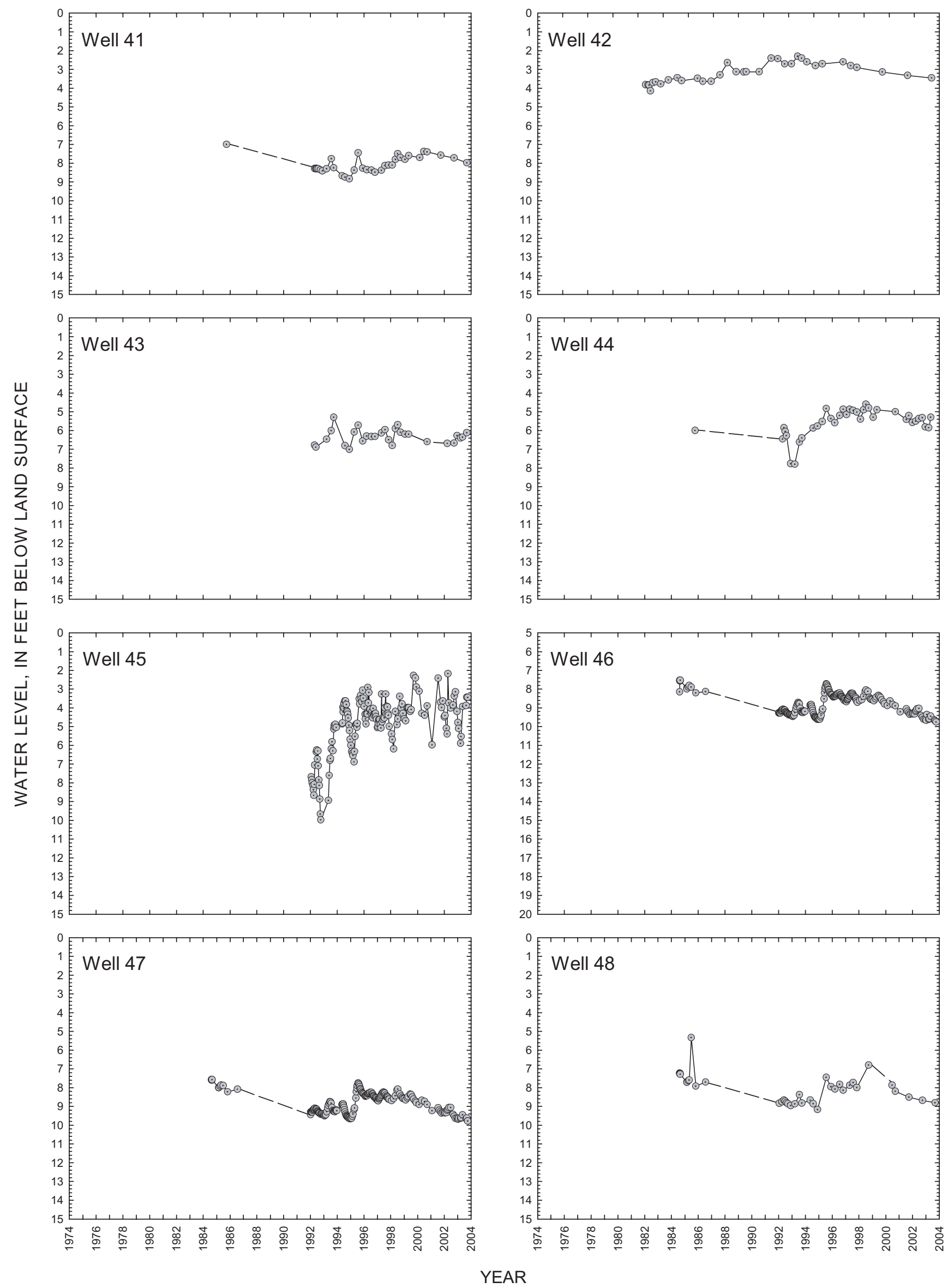


Appendix C. Changes in water levels at selected wells from the early 1990's and mid-1970's to 2003--Continued.

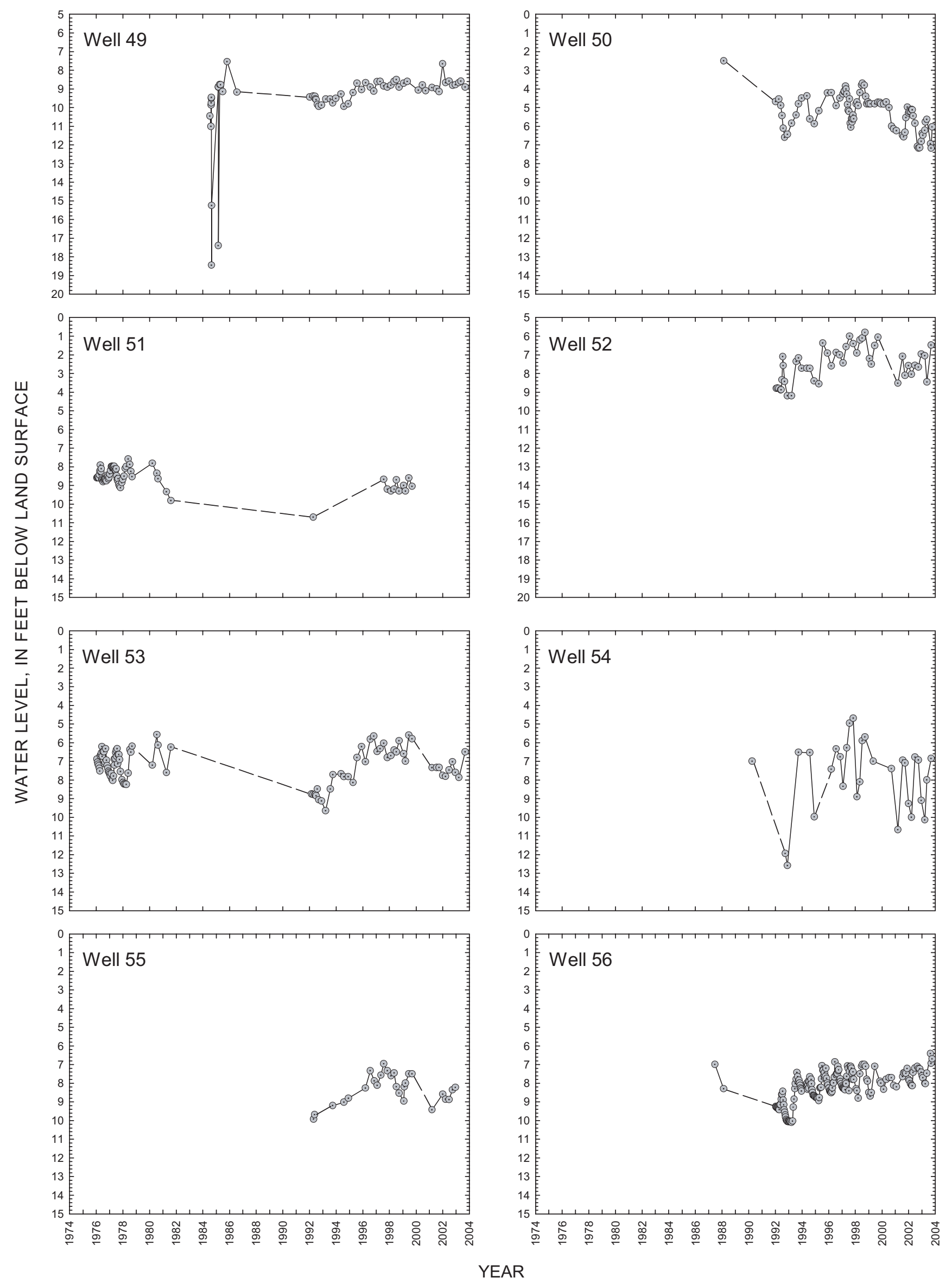


Appendix C. Changes in water levels at selected wells from the early 1990's and mid-1970's to 2003--Continued.

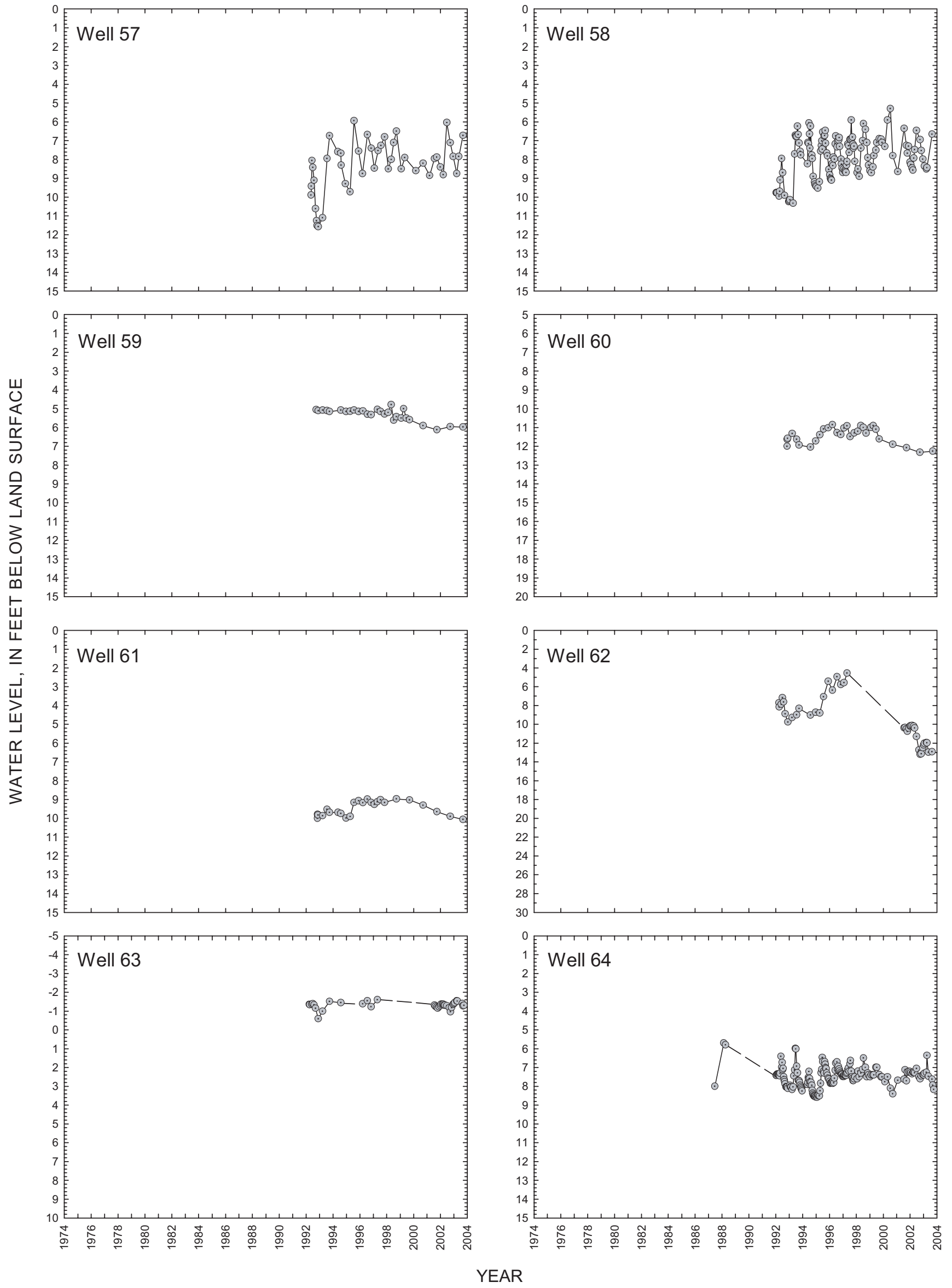


Appendix C. Changes in water levels at selected wells from the early 1990's and mid-1970's to 2003--Continued.

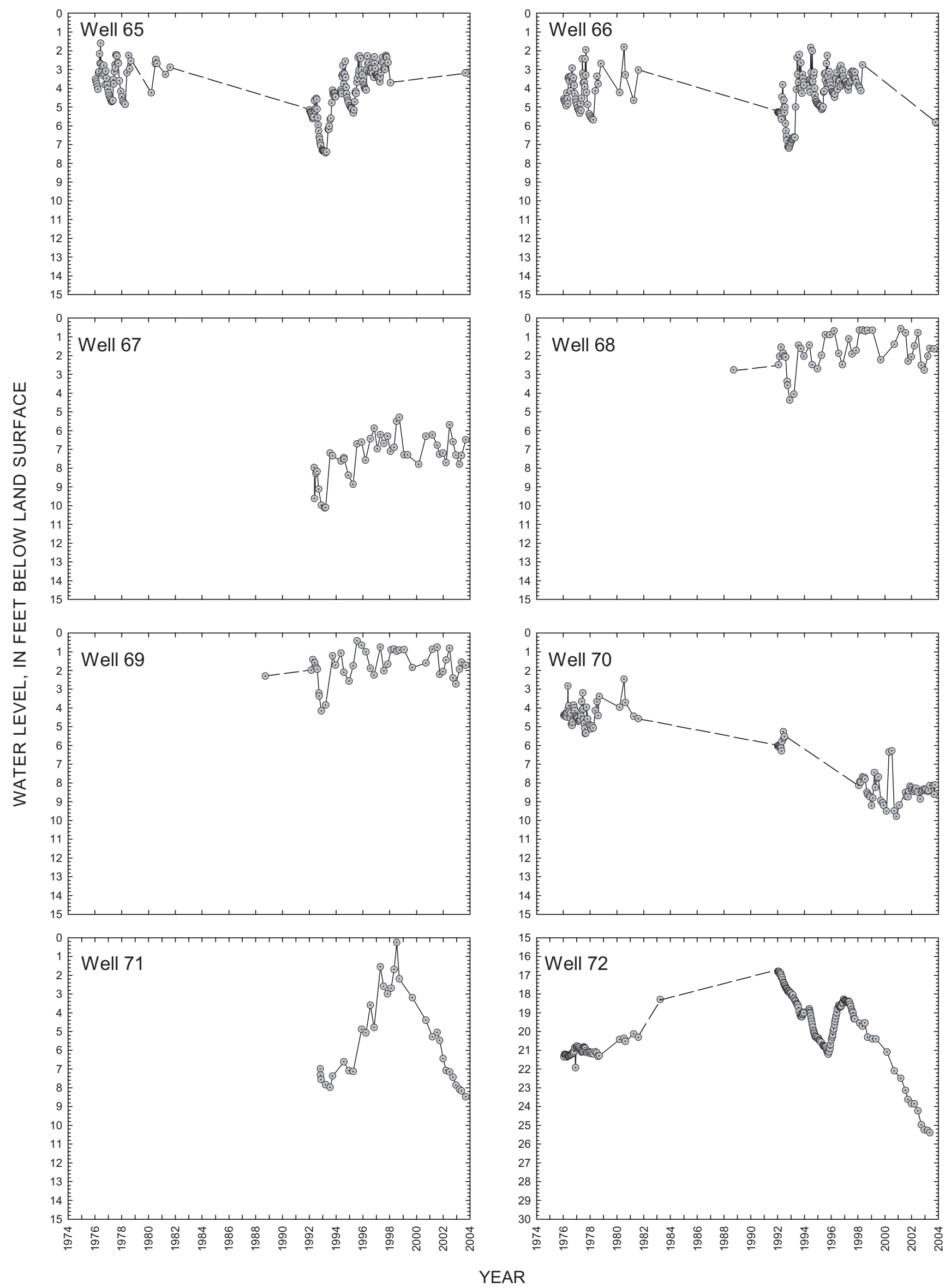


Appendix C. Changes in water levels at selected wells from the early 1990's and mid-1970's to 2003--Continued.
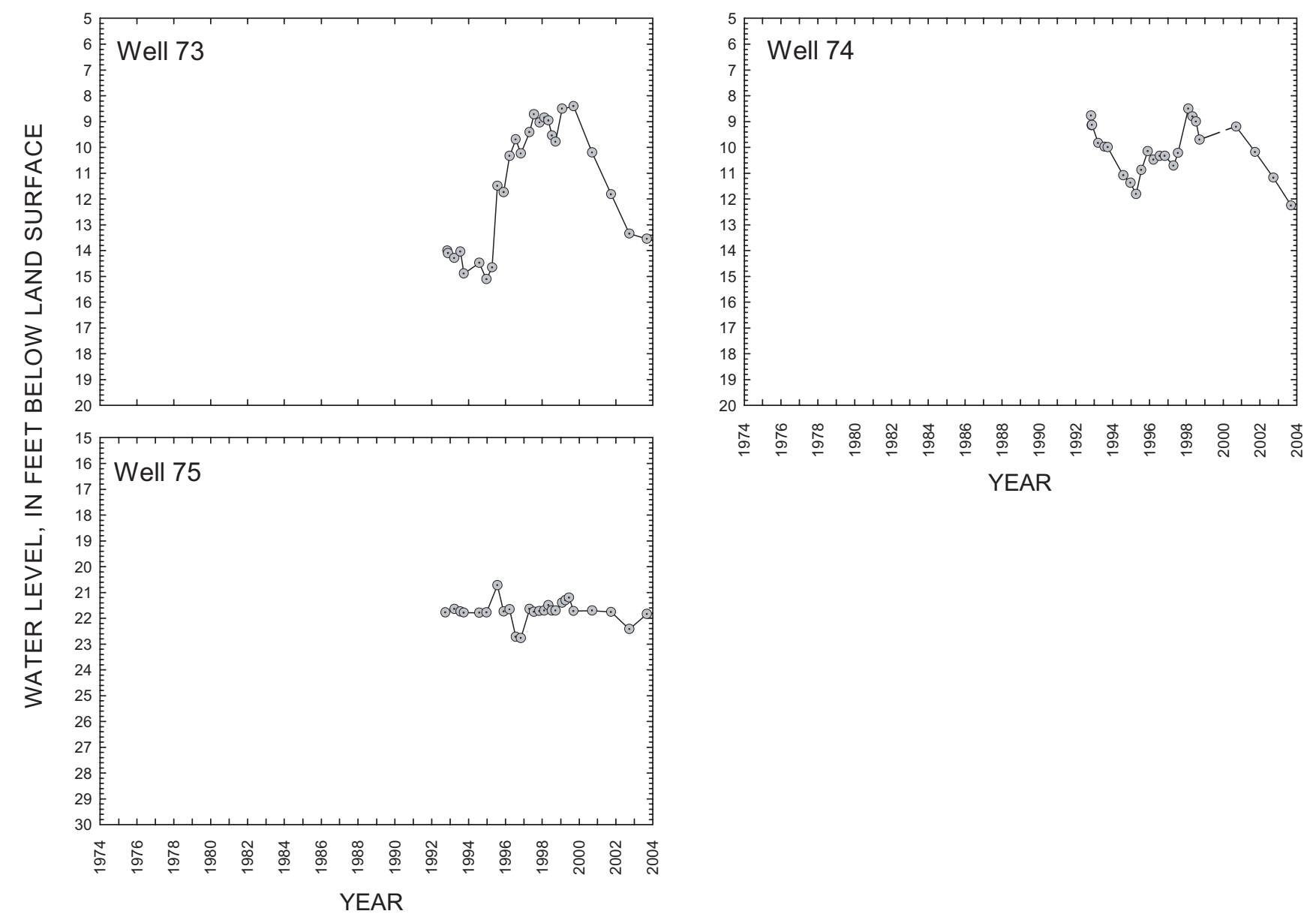
Appendix D. Summary of water-quality analyses for samples taken from monitoring wells.

[Symbols: E, estimate; <, less than; --, not analyzed; R, sequential replicate of previous analysis.]

\begin{tabular}{|c|c|c|c|c|c|c|c|c|c|c|c|c|c|c|}
\hline \multirow{2}{*}{$\begin{array}{c}\text { Site } \\
\text { number } \\
\text { (figure 3) }\end{array}$} & \multirow{2}{*}{ Date } & \multirow{2}{*}{ Time } & \multirow{2}{*}{$\begin{array}{c}\text { Temper- } \\
\text { ature } \\
\left({ }^{\circ} \mathrm{C}\right)\end{array}$} & \multicolumn{2}{|c|}{$\begin{array}{c}\text { Specific } \\
\text { conductance }\end{array}$} & \multicolumn{2}{|c|}{$\mathrm{pH}$} & \multirow{2}{*}{$\begin{array}{c}\text { Ammonia } \\
\text { as } N \\
(\mathrm{mg} / \mathrm{L})\end{array}$} & \multirow{2}{*}{$\begin{array}{c}\text { Ammonia + } \\
\text { organic } \\
\text { nitrogen } \\
\text { as N } \\
(\mathrm{mg} / \mathrm{L})\end{array}$} & \multirow{2}{*}{$\begin{array}{c}\text { Nitrite + } \\
\text { nitrate } \\
(\mathrm{mg} / \mathrm{L})\end{array}$} & \multirow{2}{*}{$\begin{array}{l}\text { Nitrite } \\
\text { as N } \\
(\mathrm{mg} / \mathrm{L})\end{array}$} & \multirow{2}{*}{$\begin{array}{c}\text { Total } \\
\text { phosphorus } \\
\text { (filtered, } \\
\text { mg/L) }\end{array}$} & \multirow{2}{*}{$\begin{array}{l}\text { Ortho- } \\
\text { phosphate } \\
\text { (filtered, } \\
\text { mg/L) }\end{array}$} & \multirow{2}{*}{$\begin{array}{c}\text { Calcium } \\
\text { as Ca } \\
(\mathrm{mg} / \mathrm{L})\end{array}$} \\
\hline & & & & $\begin{array}{l}\text { Field } \\
(\mu \mathrm{S} / \mathrm{cm})\end{array}$ & $\begin{array}{c}\text { Labora- } \\
\text { tory } \\
(\mu \mathrm{S} / \mathrm{cm})\end{array}$ & Field & $\begin{array}{l}\text { Labora- } \\
\text { tory }\end{array}$ & & & & & & & \\
\hline \multirow[t]{6}{*}{12} & $09 / 14 / 2000$ & 1200 & 20.0 & 413 & 408 & 9.1 & 9.1 & $<0.02$ & $<0.10$ & 0.22 & $<0.01$ & 1.35 & 1.4 & 0.6 \\
\hline & $02 / 27 / 2001$ & 1140 & 16.1 & 388 & 400 & 9 & 9.1 & $<.04$ & E.07 & .21 & $<.006$ & 1.21 & 1.27 & .6 \\
\hline & $11 / 20 / 2001$ & 1000 & -- & -- & 417 & 9.4 & 9 & $<.04$ & .11 & .27 & $<.008$ & .93 & 1.01 & -- \\
\hline & $06 / 20 / 2002$ & 1000 & 18 & 411 & 417 & 8.9 & 9.1 & $<.04$ & $<.1$ & .24 & $<.008$ & 1 & .99 & .6 \\
\hline & 01/29/2003 & 1100 & 164 & 470 & 420 & 9.4 & 9 & $<.04$ & E.05 & .2 & $<.008$ & .94 & .99 & .6 \\
\hline & $09 / 16 / 2003$ & 1030 & 22.4 & 460 & 426 & 8.9 & 8.9 & $<.04$ & $<.1$ & .15 & $<.008$ & .91 & .92 & .6 \\
\hline \multirow[t]{6}{*}{13} & $09 / 14 / 2000$ & 1032 & 20.5 & 288 & 295 & 8 & 8.2 & $<.02$ & $<.1$ & .81 & .015 & .34 & .33 & 10.6 \\
\hline & $02 / 28 / 2001$ & 1040 & 16.5 & 313 & 337 & 8.3 & 8.3 & $<.04$ & E.06 & .85 & $<.006$ & .35 & .39 & 12 \\
\hline & $11 / 20 / 2001$ & 1200 & 16.5 & -- & 317 & 8.5 & 8.4 & $<.04$ & $<.1$ & .77 & $<.008$ & .28 & .29 & -- \\
\hline & $06 / 20 / 2002$ & 1200 & 18 & 348 & 338 & 8.3 & 8.1 & $<.04$ & E.06 & .73 & $<.008$ & .27 & .27 & 18.4 \\
\hline & $01 / 29 / 2003$ & 1330 & 17.5 & 348 & 313 & 7.8 & 7.8 & $<.04$ & $<.1$ & .97 & E.006 & .21 & .2 & 17.5 \\
\hline & $09 / 15 / 2003$ & 1330 & 19.5 & 360 & 324 & 8.3 & 8.2 & $<.04$ & .21 & .43 & $<.008$ & .81 & .79 & 17.2 \\
\hline \multirow[t]{12}{*}{14} & 06/21/1988 & 1400 & 18 & 346 & 353 & 6.9 & 7.5 & $<.01$ & $<.2$ & .49 & $<.01$ & -- & .13 & 29 \\
\hline & $06 / 21 / 1988$ & $1400 \mathrm{R}$ & 18 & 346 & 352 & 6.9 & 7.7 & $<.01$ & .3 & .49 & $<.01$ & -- & .13 & 29 \\
\hline & $12 / 09 / 1998$ & 1200 & 15 & 225 & 229 & 7.1 & 7.4 & $<.02$ & $<.1$ & .21 & $<.01$ & .15 & .16 & 17.3 \\
\hline & $09 / 21 / 1999$ & 1015 & 19 & 240 & 238 & 6.8 & 7.3 & $<.02$ & E.09 & .2 & $<.01$ & .17 & .16 & 18.6 \\
\hline & $02 / 02 / 2000$ & 1345 & 14 & 517 & 554 & 7 & 7 & $<.02$ & .36 & 14.1 & $<.01$ & .12 & .1 & 54.5 \\
\hline & 08/07/2000 & 1010 & 20 & 275 & 281 & 7 & 7.3 & $<.02$ & E.06 & .27 & $<.01$ & .16 & .15 & 23.9 \\
\hline & $02 / 28 / 2001$ & 1225 & 13 & 364 & 393 & 6.9 & 7.1 & $<.04$ & .1 & 1 & $<.006$ & .12 & .12 & 36 \\
\hline & 03/20/2002 & 0930 & -- & -- & 603 & -- & 7.4 & $<.04$ & .23 & 4.67 & $<.008$ & .12 & .11 & 63.6 \\
\hline & $06 / 17 / 2002$ & 1030 & 15.5 & 265 & 275 & 7.3 & 7.4 & $<.04$ & E. 05 & .17 & $<.008$ & .13 & .12 & 20.6 \\
\hline & $01 / 28 / 2003$ & 1000 & 13.7 & 520 & 481 & 7.3 & 6.9 & $<.04$ & .11 & 1.71 & $<.008$ & .12 & .11 & 50.1 \\
\hline & $06 / 11 / 2003$ & 1300 & -- & -- & -- & 6.7 & -- & $<.04$ & E.05 & .13 & $<.008$ & -- & .11 & -- \\
\hline & $09 / 16 / 2003$ & 1230 & 21 & 320 & 278 & 6.8 & -- & $<.04$ & $<.1$ & .1 & $<.008$ & .16 & .14 & 22.5 \\
\hline \multirow[t]{9}{*}{31} & 08/02/1988 & 1600 & -- & -- & 15,800 & 7.5 & 6.4 & .69 & 2.50 & $<.10$ & .01 & -- & 1.2 & 360 \\
\hline & $12 / 17 / 1998$ & 1330 & 15 & 14,800 & 15,100 & 7.3 & 7.3 & .29 & 2.2 & .05 & $<.01$ & .38 & .59 & 346 \\
\hline & $09 / 22 / 1999$ & 1330 & 22 & 14,000 & 14,000 & 7.4 & 7.4 & .21 & 1.1 & $<.05$ & $<.01$ & .21 & .65 & 285 \\
\hline & 02/01/2000 & 1300 & 14.5 & 13,000 & 14,200 & 7.5 & 7.4 & .13 & .49 & $<.05$ & $<.01$ & .19 & .68 & 226 \\
\hline & 08/09/2000 & 1120 & 19 & 14,800 & 14,600 & 7.4 & 7.5 & .25 & 1.7 & $<.05$ & $<.01$ & .36 & .57 & 257 \\
\hline & 03/14/2001 & 1100 & 14 & 13,900 & 14,200 & 7.4 & 7.5 & .16 & 1.5 & $<.05$ & $<.006$ & .35 & .56 & 1150 \\
\hline & $06 / 24 / 2002$ & 1030 & -- & 10,900 & 12,700 & 7.6 & 7.5 & .30 & E1.7 & E.03 & $<.008$ & .32 & .45 & 197 \\
\hline & $02 / 03 / 2003$ & 1215 & -- & - & 12,700 & 7.3 & 7.7 & .19 & 1.3 & $<.06$ & $<.008$ & .34 & .59 & 192 \\
\hline & $09 / 19 / 2003$ & 1130 & 15 & -- & 11,600 & 7.6 & 7.7 & $<.04$ & 1 & $<.06$ & $<.008$ & .34 & .46 & 258 \\
\hline
\end{tabular}




\begin{tabular}{|c|c|c|c|c|c|c|c|c|c|c|c|c|c|c|}
\hline \multirow{2}{*}{$\begin{array}{c}\text { Site } \\
\text { number } \\
\text { (figure 3) }\end{array}$} & \multirow{2}{*}{ Date } & \multirow{2}{*}{ Time } & \multirow{2}{*}{$\begin{array}{l}\text { Temper- } \\
\text { ature } \\
\left({ }^{\circ} \mathrm{C}\right)\end{array}$} & \multicolumn{2}{|c|}{$\begin{array}{c}\text { Specific } \\
\text { conductance }\end{array}$} & \multicolumn{2}{|c|}{$\mathrm{pH}$} & \multirow{2}{*}{$\begin{array}{c}\text { Ammonia } \\
\text { as N } \\
(\mathrm{mg} / \mathrm{L})\end{array}$} & \multirow{2}{*}{$\begin{array}{c}\text { Ammonia + } \\
\text { organic } \\
\text { nitrogen } \\
\text { as } N \\
(\mathrm{mg} / \mathrm{L})\end{array}$} & \multirow{2}{*}{$\begin{array}{c}\text { Nitrite + } \\
\text { nitrate } \\
(\mathrm{mg} / \mathrm{L})\end{array}$} & \multirow{2}{*}{$\begin{array}{l}\text { Nitrite } \\
\text { as N } \\
\text { (mg/L) }\end{array}$} & \multirow{2}{*}{$\begin{array}{l}\text { Total } \\
\text { phosphorus } \\
\text { (filtered, } \\
\text { mg/L) }\end{array}$} & \multirow{2}{*}{$\begin{array}{l}\text { Ortho- } \\
\text { phosphate } \\
\text { (filtered, } \\
\text { mg/L) }\end{array}$} & \multirow{2}{*}{$\begin{array}{c}\text { Calcium } \\
\text { as Ca } \\
\text { (mg/L) }\end{array}$} \\
\hline & & & & $\begin{array}{c}\text { Field } \\
(\mu \mathrm{S} / \mathrm{cm})\end{array}$ & $\begin{array}{c}\text { Labora- } \\
\text { tory } \\
(\mu \mathrm{S} / \mathrm{cm})\end{array}$ & Field & $\begin{array}{l}\text { Labora- } \\
\text { tory }\end{array}$ & & & & & & & \\
\hline \multirow[t]{12}{*}{39} & 08/02/1988 & 1200 & 16.5 & 5,030 & 4,880 & 6.7 & 7.4 & .16 & 1 & $<.1$ & $<.01$ & -- & .42 & 110 \\
\hline & 05/03/1989 & 1315 & 15 & 5,910 & 5,690 & 7 & 7.2 & -- & -- & -- & -- & -- & -- & 380 \\
\hline & 08/22/1994 & 1300 & 17 & 6,040 & 6,110 & 6.9 & 7.1 & .17 & 1.4 & $<.05$ & $<.01$ & .39 & .39 & 580 \\
\hline & $12 / 15 / 1998$ & 1315 & 14 & 1,430 & 1,570 & 7 & 7.1 & .11 & .96 & $<.05$ & $<.01$ & .6 & .46 & 80.5 \\
\hline & 09/23/1999 & 1130 & 16.5 & 1,680 & 1,660 & 7 & 7.1 & .47 & 1.2 & $<.05$ & $<.01$ & .73 & .76 & 96.1 \\
\hline & $01 / 31 / 2000$ & 1230 & 12.5 & 1,640 & 1,770 & 6.9 & 7.2 & .22 & 1.5 & $<.05$ & $<.01$ & .43 & .45 & 88.6 \\
\hline & $08 / 08 / 2000$ & 1015 & 17.5 & 1,850 & 1,920 & 6.9 & 7.1 & .34 & 1.5 & $<.05$ & $<.01$ & .92 & .96 & 120 \\
\hline & 03/1/2001 & 1315 & 12.5 & 1,550 & 1,690 & 7 & 7.1 & .19 & .9 & $<.05$ & $<.006$ & .66 & .56 & 86.8 \\
\hline & $03 / 21 / 2002$ & 1045 & 13 & 2,350 & 2,290 & 7.2 & 7.4 & .13 & .93 & $<.05$ & $<.008$ & .64 & .62 & 139 \\
\hline & $06 / 18 / 2002$ & 1045 & 17.5 & 2,100 & 2,270 & 7.4 & 7.4 & .13 & .95 & $<.05$ & $<.008$ & .86 & .14 & 133 \\
\hline & $01 / 28 / 2003$ & 1300 & 13 & 1,360 & 1,650 & 7.4 & 7.7 & .12 & .68 & $<.06$ & $<.008$ & .6 & .58 & 89.3 \\
\hline & $09 / 17 / 2003$ & 1300 & 19 & 1,710 & 1,510 & 6.9 & 7.3 & .2 & .88 & $<.06$ & $<.008$ & .74 & .68 & 89.4 \\
\hline \multirow[t]{11}{*}{50} & 08/03/1988 & 1000 & 15.5 & 1,440 & 1,690 & 8.1 & 8.3 & .02 & .60 & 1.30 & .03 & -- & .25 & 16.0 \\
\hline & 09/01/1988 & 1530 & 17 & 1,740 & -- & 8 & -- & -- & -- & -- & -- & -- & -- & -- \\
\hline & $12 / 11 / 1998$ & 1140 & 12.5 & 1,490 & 1,560 & 7.7 & 7.8 & .02 & .55 & .95 & .031 & .17 & .2 & 32.3 \\
\hline & 09/22/1999 & 1130 & 14.5 & 1,610 & 1,620 & 7.6 & 7.8 & $<.02$ & .5 & .4 & .016 & .19 & .22 & 36.4 \\
\hline & $02 / 01 / 2000$ & 1110 & 12 & 1,690 & 1,610 & 7.9 & 7.8 & $<.02$ & .49 & .33 & .022 & .19 & .2 & 33.1 \\
\hline & 08/08/2000 & 1220 & 17 & 1,400 & 1,410 & 7.7 & 7.9 & $<.02$ & .51 & .34 & .013 & .21 & .21 & 28 \\
\hline & $03 / 02 / 2001$ & 1030 & 9.5 & 1,340 & 1,420 & 7.7 & 7.8 & $<.04$ & .4 & .18 & .012 & .22 & .23 & 27.6 \\
\hline & $03 / 21 / 2002$ & 1300 & -- & 1,030 & 1,150 & 7.9 & 8.1 & $<.04$ & .38 & .31 & .017 & .19 & .18 & 24.2 \\
\hline & $06 / 18 / 2002$ & 1230 & 15.2 & 1,100 & 1,160 & 7.7 & 7.9 & $<.04$ & .37 & .20 & .012 & .17 & .17 & 28.6 \\
\hline & $02 / 03 / 2003$ & 1030 & 12.7 & 1,000 & 1,320 & 7.5 & 7.8 & $<.04$ & .42 & .15 & .012 & .16 & .16 & 43.7 \\
\hline & $09 / 17 / 2003$ & 1430 & 16.3 & 1,450 & 1,260 & 7.5 & 7.8 & $<.04$ & .36 & .13 & E.006 & .16 & .15 & 45.9 \\
\hline \multirow[t]{11}{*}{64} & 07/13/1988 & 1300 & 17.5 & $>20,000$ & 20,100 & 7.3 & 7.4 & .69 & 2.1 & $<.10$ & $<.01$ & -- & .51 & 140 \\
\hline & $12 / 10 / 1998$ & 1200 & 14 & 1,250 & 1,360 & 8.1 & 8.1 & .04 & .47 & $<.05$ & $<.01$ & 2.7 & 2.77 & 1.6 \\
\hline & 09/21/1999 & 1245 & 18.5 & 1,400 & 1,370 & 7.8 & 8.1 & $<.02$ & .39 & $<.05$ & $<.01$ & .08 & 2.63 & 1.6 \\
\hline & $02 / 04 / 2000$ & 1140 & 14.5 & 1,600 & 1,680 & 8 & 8 & .03 & .91 & $<.05$ & $<.01$ & .57 & 1.94 & 2.9 \\
\hline & $08 / 07 / 2000$ & 1240 & 18.5 & 1,510 & 1,540 & 7.8 & 8.1 & $<.02$ & .39 & $<.05$ & $<.01$ & 2.25 & 2.29 & 2.1 \\
\hline & 03/01/2001 & 1055 & 13.5 & 1,510 & 1,570 & 7.8 & 7.9 & $<.04$ & .29 & $<.05$ & $<.006$ & 2.1 & 2.3 & 2.5 \\
\hline & $03 / 20 / 2002$ & 1130 & 13.5 & 1,480 & 1,920 & 7.9 & 8 & .11 & .38 & E.03 & E.007 & 2.06 & 1.99 & 4.2 \\
\hline & $06 / 17 / 2002$ & 1245 & 15.6 & 1,860 & 1,880 & 7.8 & 8 & .05 & .41 & .19 & $<.008$ & 1.98 & 2.2 & 3.4 \\
\hline & 06/17/2002 & $1245 R$ & -- & -- & 1,890 & -- & 8 & .05 & .43 & $<.05$ & E.004 & 1.97 & 2.02 & 3.4 \\
\hline & $01 / 30 / 2003$ & 1330 & 15 & 1,560 & 1,580 & 7.8 & 8.1 & E.04 & .17 & $<.06$ & $<.008$ & 1.74 & 1.78 & 2.2 \\
\hline & $09 / 17 / 2003$ & 1030 & 19.5 & 1,910 & 1,780 & 7.7 & 8 & E.03 & .22 & $<.06$ & $<.008$ & 1.23 & 1.25 & 2.9 \\
\hline
\end{tabular}


Appendix D. Summary of water-quality analyses for samples taken from monitoring wells-Continued

\begin{tabular}{|c|c|c|c|c|c|c|c|c|c|c|c|c|c|}
\hline $\begin{array}{c}\text { Site } \\
\text { number } \\
\text { (figure 3) }\end{array}$ & Date & $\begin{array}{l}\text { Magnesium } \\
\text { as Mg } \\
(\mathrm{mg} / \mathrm{L})\end{array}$ & $\begin{array}{l}\text { Sodium } \\
\text { as } \\
\mathrm{Na} \\
\text { (mg/L) }\end{array}$ & $\begin{array}{c}\text { Potassium } \\
\text { as K } \\
(\mathrm{mg} / \mathrm{L})\end{array}$ & $\begin{array}{c}\text { Alkalinity } \\
\text { as } \mathrm{CaCO}_{3} \\
(\mathrm{mg} / \mathrm{L})\end{array}$ & $\begin{array}{l}\text { Sulfate } \\
\text { as } \mathrm{SO}_{4} \\
(\mathrm{mg} / \mathrm{L})\end{array}$ & $\begin{array}{c}\text { Chloride } \\
\text { as Cl } \\
\text { (mg/L) }\end{array}$ & $\begin{array}{c}\text { Fluoride } \\
\text { as } F \\
(\mathrm{mg} / \mathrm{L})\end{array}$ & $\begin{array}{c}\text { Bromide } \\
\text { as } \mathrm{Br} \\
(\mathrm{mg} / \mathrm{L})\end{array}$ & $\begin{array}{c}\text { Silica } \\
\text { as } \mathrm{SiO}_{2} \\
(\mathrm{mg} / \mathrm{L})\end{array}$ & $\begin{array}{l}\text { Iron } \\
\text { as Fe } \\
(\mu \mathrm{g} / L)\end{array}$ & $\begin{array}{c}\text { Manganese } \\
\text { as Mn } \\
(\mu \mathbf{g} / L)\end{array}$ & $\begin{array}{c}\text { Residue } \\
\text { at } \\
180^{\circ} \mathrm{C} \\
(\mathrm{mg} / \mathrm{L})\end{array}$ \\
\hline \multirow[t]{6}{*}{12} & $09 / 14 / 2000$ & 0.1 & -- & -- & 143 & 35.1 & 8.5 & 0.6 & -- & -- & -- & -- & -- \\
\hline & $02 / 27 / 2001$ & .1 & -- & -- & 144 & 35.2 & 8.3 & .6 & -- & -- & -- & -- & -- \\
\hline & $11 / 20 / 2001$ & -- & 91 & 3 & 156 & -- & -- & -- & 0.03 & 34.7 & E6 & $<2.0$ & 284 \\
\hline & $06 / 20 / 2002$ & .1 & 94 & 2.8 & 150 & 34.7 & 9 & .4 & E.02 & 34.2 & 13 & $<2$ & 277 \\
\hline & $01 / 29 / 2003$ & .1 & 96 & 3.1 & 164 & 35.9 & 8.4 & .4 & .04 & 34.3 & 68 & 3.1 & 285 \\
\hline & $09 / 16 / 2003$ & .1 & 102 & 3.2 & 153 & 34.9 & 9.1 & .4 & .04 & 35.2 & 40 & .6 & 301 \\
\hline \multirow[t]{6}{*}{13} & $09 / 14 / 2000$ & 2.6 & -- & -- & 94 & 27.7 & 6.8 & .4 & -- & -- & -- & -- & -- \\
\hline & $02 / 28 / 2001$ & 2.6 & -- & -- & 110 & 36.2 & 8.1 & .4 & -- & -- & -- & -- & -- \\
\hline & $11 / 20 / 2001$ & -- & 40 & 7 & 98 & -- & -- & -- & .03 & 27.7 & $<10$ & $<2$ & 210 \\
\hline & $06 / 20 / 2002$ & 5.3 & 39 & 7.1 & 476 & 37.6 & 13.4 & .3 & .03 & 28.4 & $<10$ & $<2$ & 216 \\
\hline & $01 / 29 / 2003$ & 5.2 & 36 & 7.2 & 94 & 34.5 & 13.3 & .3 & .04 & 28.5 & $<10$ & $<2$ & 207 \\
\hline & $09 / 15 / 2003$ & 5.2 & 42 & 6.4 & 94 & 34.4 & 15.2 & .4 & .06 & 29.3 & 218 & -- & -- \\
\hline \multirow[t]{12}{*}{14} & $06 / 21 / 1988$ & 7.4 & 31 & 3.6 & 99 & 39 & 18 & .3 & -- & 17 & 4 & 3 & -- \\
\hline & $06 / 21 / 1988$ & 7.4 & 31 & 3.3 & 99 & 39 & 19 & .4 & -- & 17 & 4 & 4 & -- \\
\hline & $12 / 09 / 1998$ & 4.7 & 19 & 3.3 & 73 & 22.9 & 6.3 & .2 & -- & 21.2 & $<10$ & $<3$ & 149 \\
\hline & 09/21/1999 & 5.1 & 21 & 3.8 & 80 & 24.7 & 6.2 & .2 & -- & 23.5 & $<10$ & $<2.2$ & 154 \\
\hline & $02 / 02 / 2000$ & 14.8 & -- & -- & 130 & 51.8 & 17.4 & .2 & -- & -- & -- & -- & -- \\
\hline & $08 / 07 / 2000$ & 6.1 & -- & -- & 85 & 34.3 & 7.5 & .3 & -- & -- & -- & -- & -- \\
\hline & $02 / 28 / 2001$ & 9.4 & -- & -- & 96 & 56.8 & 17 & .2 & -- & -- & -- & -- & -- \\
\hline & $03 / 20 / 2002$ & 17 & 39 & 5.3 & 212 & 60.5 & 17.5 & .2 & .05 & 21 & $<10$ & $<2$ & 386 \\
\hline & $06 / 17 / 2002$ & 5.5 & 24 & 3.4 & 52 & 31.1 & 16.2 & .2 & .03 & 20.7 & $<10$ & $<2$ & 166 \\
\hline & $01 / 28 / 2003$ & 12.2 & 34 & 4.8 & 131 & 51.3 & 18.6 & .2 & .04 & 20.9 & $<10$ & $<2$ & 302 \\
\hline & $06 / 11 / 2003$ & -- & -- & -- & -- & -- & -- & -- & -- & -- & -- & -- & 175 \\
\hline & $09 / 16 / 2003$ & 5.8 & 27 & 4.2 & 81 & 31.9 & 12.8 & -- & .04 & 24.5 & $<8$ & $<.4$ & 187 \\
\hline \multirow[t]{9}{*}{31} & 08/02/1988 & 220 & 3,500 & 26 & 1,400 & 5,200 & 2,400 & 1.6 & -- & 53.0 & 89 & 5,400 & -- \\
\hline & $12 / 17 / 1998$ & 261 & 4,150 & 51.4 & 770 & 5,180 & 2,030 & 1.4 & -- & 73.0 & $<200$ & 2,830 & 11,800 \\
\hline & 09/22/1999 & 220 & 3,800 & 50.7 & 875 & 4,770 & 1,900 & 1.8 & -- & 76.8 & $<10$ & 2,090 & 11,200 \\
\hline & $02 / 01 / 2000$ & 161 & -- & -- & 920 & 4,270 & 1,820 & 1.6 & -- & -- & -- & -- & -- \\
\hline & $08 / 09 / 2000$ & 181 & -- & -- & 962 & 5,100 & 2,010 & 2.1 & -- & -- & -- & -- & -- \\
\hline & 03/14/2001 & 864 & -- & -- & 909 & 4,630 & 1,790 & 1.5 & -- & -- & -- & -- & -- \\
\hline & $06 / 24 / 2002$ & 158 & 2,830 & 42.9 & 831 & 4,630 & 1,670 & 1.5 & 2.27 & 58.0 & 111 & 1,650 & 10,800 \\
\hline & $02 / 03 / 2003$ & 152 & 2,880 & 43.2 & 866 & 3,940 & 1,430 & 1.7 & 1.92 & 62.5 & $<100$ & 1,310 & 9,740 \\
\hline & $09 / 19 / 2003$ & 208 & 2,920 & 65.4 & 838 & 4,430 & 1,540 & 2 & 2.1 & 86.8 & $28 \mathrm{E}$ & 796 & 10,600 \\
\hline
\end{tabular}




\begin{tabular}{|c|c|c|c|c|c|c|c|c|c|c|c|c|c|}
\hline $\begin{array}{c}\text { Site } \\
\text { number } \\
\text { (figure 3) }\end{array}$ & Date & $\begin{array}{c}\text { Magnesium } \\
\text { as Mg } \\
(\mathrm{mg} / \mathrm{L})\end{array}$ & $\begin{array}{l}\text { Sodium } \\
\text { as } \\
\mathrm{Na} \\
\text { (mg/L) }\end{array}$ & $\begin{array}{l}\text { Potassium } \\
\text { as K } \\
\text { (mg/L) }\end{array}$ & $\begin{array}{c}\text { Alkalinity } \\
\text { as } \mathrm{CaCO}_{3} \\
(\mathrm{mg} / \mathrm{L})\end{array}$ & $\begin{array}{l}\text { Sulfate } \\
\text { as } \mathrm{SO}_{4} \\
\text { (mg/L) }\end{array}$ & $\begin{array}{c}\text { Chloride } \\
\text { as Cl } \\
(\mathrm{mg} / \mathrm{L})\end{array}$ & $\begin{array}{c}\text { Fluoride } \\
\text { as F } \\
(\mathrm{mg} / \mathrm{L})\end{array}$ & $\begin{array}{c}\text { Bromide } \\
\text { as } \mathrm{Br} \\
(\mathrm{mg} / \mathrm{L})\end{array}$ & $\begin{array}{c}\text { Silica } \\
\text { as } \mathrm{SiO}_{2} \\
(\mathrm{mg} / \mathrm{L})\end{array}$ & $\begin{array}{l}\text { Iron } \\
\text { as Fe } \\
(\mu \mathrm{g} / L)\end{array}$ & $\begin{array}{c}\text { Manganese } \\
\text { as Mn } \\
(\mu g / L)\end{array}$ & $\begin{array}{c}\text { Residue } \\
\text { at } \\
180^{\circ} \mathrm{C} \\
(\mathrm{mg} / \mathrm{L})\end{array}$ \\
\hline \multirow[t]{12}{*}{39} & 08/02/1988 & 37 & 230 & 15 & 650 & -- & -- & -- & -- & 14.0 & 4 & 660 & -- \\
\hline & 05/03/1989 & 140 & 760 & 22 & 655 & 1,100 & 1,000 & .8 & -- & 40.0 & 14 & 1,700 & -- \\
\hline & 08/22/1994 & 180 & 640 & 22 & -- & 1,500 & 1,000 & $<.10$ & .89 & .1 & 30 & $>1,000$ & 4,670 \\
\hline & $12 / 15 / 1998$ & 24.6 & 247 & 11.9 & 521 & 162 & 54.9 & 1.2 & -- & 38.1 & 776 & 606 & 1,000 \\
\hline & 09/23/1999 & 28.9 & 244 & 10.5 & 570 & 214 & 78.4 & 1.1 & -- & 44.0 & 759 & 759 & 1,100 \\
\hline & $01 / 31 / 2000$ & 26.8 & -- & -- & 532 & 224 & 84.0 & 1.2 & -- & -- & -- & -- & -- \\
\hline & $08 / 08 / 2000$ & 32.6 & -- & -- & 609 & 271 & 115.0 & 1 & -- & -- & -- & -- & -- \\
\hline & 03/01/2001 & 26.5 & -- & -- & 636 & 171 & 73.9 & 1.2 & -- & -- & -- & -- & -- \\
\hline & $03 / 21 / 2002$ & 41.7 & 333 & 14.2 & 709 & 358 & 128.0 & 1.3 & .34 & 37.3 & 1,440 & 1,020 & 1,560 \\
\hline & $06 / 18 / 2002$ & 39.6 & 347 & 12.6 & 699 & 339 & 136.0 & 1.3 & .22 & 35.8 & 1,700 & 922 & 1,570 \\
\hline & $01 / 28 / 2003$ & 26.6 & 262 & 11.3 & 613 & 193 & 81.5 & 1.2 & .11 & 38.2 & 1,060 & 705 & 1,110 \\
\hline & $09 / 17 / 2003$ & 26.5 & 244 & 13.6 & 488 & 194 & 95.9 & 1.2 & .07 & 44.5 & 1,030 & 639 & 1,040 \\
\hline \multirow[t]{11}{*}{50} & 08/03/1988 & 4.0 & 370 & 9.8 & 434 & 290 & 120 & .8 & -- & 40.0 & 70 & 14 & -- \\
\hline & 09/01/1988 & -- & -- & -- & -- & -- & -- & -- & -- & -- & -- & -- & -- \\
\hline & $12 / 11 / 1998$ & 9.7 & 288 & 14.7 & 475 & 249 & 65.6 & .7 & -- & 42.8 & $<10$ & 46.2 & 1,030 \\
\hline & 09/22/1999 & 10.9 & 309 & 16.1 & 483 & 255 & 63.8 & .7 & -- & 44.1 & $<10$ & 93.9 & 1,080 \\
\hline & $02 / 01 / 2000$ & 10 & -- & -- & 501 & 233 & 57.9 & .7 & -- & -- & -- & -- & -- \\
\hline & 08/08/2000 & 8.5 & -- & -- & 481 & 191 & 54.2 & .8 & -- & -- & -- & -- & -- \\
\hline & $03 / 02 / 2001$ & 7.9 & -- & -- & 486 & 178 & 51.5 & .9 & -- & -- & -- & -- & -- \\
\hline & $03 / 21 / 2002$ & 7.2 & 226 & 10.8 & 375 & 157 & 45.0 & .8 & .05 & 41.6 & $<10$ & 18.5 & 783 \\
\hline & $06 / 18 / 2002$ & 8.5 & 231 & 11.4 & 373 & 154 & 45.8 & .7 & E.03 & 42.3 & $<10$ & 31.5 & 780 \\
\hline & $02 / 03 / 2003$ & 12.5 & 262 & 12.8 & 450 & 198 & 56.1 & .7 & .03 & 45.0 & $<10$ & 45.8 & 922 \\
\hline & $09 / 17 / 2003$ & 13.5 & 242 & 14.3 & 393 & 181 & 59.2 & .6 & .06 & 50.8 & $<8$ & 118 & 845 \\
\hline \multirow[t]{11}{*}{64} & 07/13/1988 & 300 & 4,500 & 79 & 852 & 3,500 & 5,200 & .3 & -- & 31.0 & 270 & 1,700 & -- \\
\hline & $12 / 10 / 1998$ & 2.4 & 291 & 7.7 & 326 & 99.5 & 191 & 1.5 & -- & 26.6 & 54 & 23.4 & 816 \\
\hline & 09/21/1999 & 2.5 & 297 & 8.6 & 368 & 70.0 & 148 & 2.0 & -- & 27.0 & 28 & 19.2 & 814 \\
\hline & $02 / 04 / 2000$ & 3.9 & -- & -- & 492 & 63.6 & 180 & 1.4 & -- & -- & -- & -- & -- \\
\hline & $08 / 07 / 2000$ & 3.5 & -- & -- & 460 & 73.3 & 171 & 1.2 & -- & -- & -- & -- & -- \\
\hline & 03/01/2001 & 3.6 & -- & -- & 511 & 60.4 & 159 & 1.3 & -- & -- & -- & -- & -- \\
\hline & $03 / 20 / 2002$ & 5.1 & 401 & 12 & 489 & 96.5 & 237 & 1.2 & .46 & 25.7 & $<10$ & 50.4 & 1,130 \\
\hline & $06 / 17 / 2002$ & 4.7 & 398 & 10.3 & 456 & 114 & 237 & 1.1 & .32 & 24.9 & 31 & 42 & 1,130 \\
\hline & $06 / 17 / 2002$ & 4.8 & 407 & 10.4 & & 113 & 237 & 1.2 & .34 & 25.8 & 31 & 42.5 & 1,130 \\
\hline & $01 / 30 / 2003$ & 3.5 & 357 & 9.6 & 413 & 44.5 & 236 & .8 & .41 & 26.3 & 23 & 16.3 & 943 \\
\hline & 09/17/2003 & 4.6 & 391 & 11.8 & 453 & 70.1 & 251 & .6 & .47 & 29.4 & 25 & 28 & 1,100 \\
\hline
\end{tabular}


Since 1879, the U.S. Geological Survey has been providing maps, reports, and information to help others who manage, develop, and protect our Nation's water, energy, mineral, land, and biological resources. We help find natural resources, and we supply scientific understanding needed to help minimize or mitigate the effects of natural hazards and the environmental damage caused by human activities. The results of our efforts touch the daily lives of almost everyone. 